\title{
Overview of the Chemistry-Aerosol Mediterranean Experiment/Aerosol Direct Radiative Forcing on the Mediterranean Climate (ChArMEx/ADRIMED) summer 2013 campaign
}

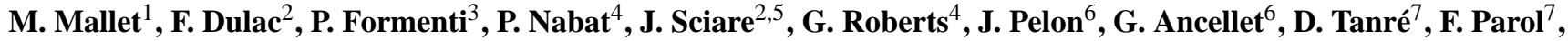 \\ C. Denjean ${ }^{3,4}$, G. Brogniez ${ }^{7}$, A. di Sarra ${ }^{8}$, L. Alados-Arboledas ${ }^{9}$, J. Arndt ${ }^{10}$, F. Auriol ${ }^{7}$, L. Blarel ${ }^{7}$, T. Bourrianne ${ }^{4}$, \\ P. Chazette ${ }^{2}$, S. Chevaillier ${ }^{3}$, M. Claeys ${ }^{4}$, B. D’Anna ${ }^{11}$, Y. Derimian ${ }^{7}$, K. Desboeufs ${ }^{3}$, T. Di Iorio ${ }^{8}$, J.-F. Doussin ${ }^{3}$, \\ P. Durand ${ }^{1}$, A. Féron ${ }^{3}$, E. Freney ${ }^{12}$, C. Gaimoz ${ }^{3}$, P. Goloub ${ }^{7}$, J. L. Gómez-Amo ${ }^{8}$, M. J. Granados-Muñoz ${ }^{9}$, N. Grand ${ }^{3}$, \\ E. Hamonou ${ }^{2}$, I. Jankowiak ${ }^{7}$, M. Jeannot ${ }^{13}$, J.-F. Léon ${ }^{1}$, M. Maillé ${ }^{3}$, S. Mailler ${ }^{14}$, D. Meloni ${ }^{8}$, L. Menut ${ }^{14}$, \\ G. Momboisse $^{4}$, J. Nicolas ${ }^{4,12}$, T. Podvin ${ }^{7}$, V. Pont ${ }^{1}$, G. Rea ${ }^{14}$, J.-B. Renard $^{13}$, L. Roblou ${ }^{1}$, K. Schepanski ${ }^{15}$, \\ A. Schwarzenboeck ${ }^{12}$, K. Sellegri' ${ }^{12}$, M. Sicard ${ }^{16}$, F. Solmon ${ }^{17}$, S. Somot ${ }^{4}$, B Torres ${ }^{7}$, J. Totems ${ }^{2}$, S. Triquet $^{3}$,

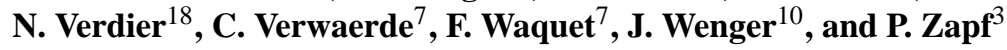 \\ ${ }^{1}$ Laboratoire d'Aérologie, Observatoire Midi-Pyrénées, 14 Avenue Edouard Belin, Toulouse, France \\ ${ }^{2}$ Laboratoire des Sciences du Climat et de l'Environnement, LSCE/IPSL, CEA-CNRSUVSQ, Université Paris-Saclay, \\ Gif-sur-Yvette, France \\ ${ }^{3}$ Laboratoire Inter-Universitaire des Systèmes Atmosphériques (LISA), UMR CNRS 7583, Université Paris Est Créteil et \\ Université Paris Diderot, Institut Pierre Simon Laplace, Créteil, France \\ ${ }^{4}$ Météo-France, CNRM-GAME, Centre National de Recherches Météorologiques, UMR3589, Toulouse, France \\ ${ }^{5}$ The Cyprus Institute, Energy, Environment and Water Research Center, Nicosia, Cyprus \\ ${ }^{6}$ LATMOS-ISPL, UPMC Univ. Paris 06 et Université Versailles St-Quentin; CNRS/INSU, Paris, France \\ ${ }^{7}$ LOA, Université Lille 1, Villeneuve d'Ascq, France \\ ${ }^{8}$ ENEA, Laboratory for Earth Observations and Analyses, Via Anguillarese 301, Rome, Italy \\ ${ }^{9}$ Department of Applied Physics, University of Granada, Granada, Spain \\ ${ }^{10}$ Department of Chemistry and Environmental Research Institute, University College Cork, Cork, Ireland \\ ${ }^{11}$ Institut de Recherches sur la Catalyse et l'Environnement de Lyon (IRCELYON), University of Lyon, \\ Villeurbanne, France \\ ${ }^{12}$ Laboratoire de Météorologie Physique, CNRS UMR6016, Observatoire de Physique du Globe de Clermont-Ferrand, \\ Université Blaise Pascal, Aubière, France \\ ${ }^{13}$ LPC2E-CNRS/Université d'Orléans, 3A Avenue de la recherche scientifique, Orléans, France \\ ${ }^{14}$ LMD, IPSL, CNRS, Ecole Polytechnique, École Normale Supérieure, Université Paris 6, UMR8539, \\ Palaiseau CEDEX, France \\ ${ }^{15}$ Leibniz Institute for Tropospheric Research, Permoserstr. 15, 04318 Leipzig, Germany \\ ${ }^{16}$ RSLab/CTE-CRAE-IEEC, Universitat Politècnica de Catalunya, Barcelona, Spain \\ ${ }^{17}$ The Abdus Salam International Center for Theoretical Physics, Strada Costiera 11, Trieste, Italy \\ ${ }^{18}$ Centre National d'Etudes Spatiales (CNES), DCT/BL/NB, 18 Avenue Edouard Belin, Toulouse, France
}

Correspondence to: M. Mallet (malm@aero.obs-mip.fr)

Received: 19 June 2015 - Published in Atmos. Chem. Phys. Discuss.: 17 July 2015

Revised: 11 December 2015 - Accepted: 14 December 2015 - Published: 19 January 2016

Published by Copernicus Publications on behalf of the European Geosciences Union. 
Abstract. The Chemistry-Aerosol Mediterranean Experiment (ChArMEx; http://charmex.lsce.ipsl.fr) is a collaborative research program federating international activities to investigate Mediterranean regional chemistry-climate interactions. A special observing period (SOP-1a) including intensive airborne measurements was performed in the framework of the Aerosol Direct Radiative Impact on the regional climate in the MEDiterranean region (ADRIMED) project during the Mediterranean dry season over the western and central Mediterranean basins, with a focus on aerosol-radiation measurements and their modeling. The SOP-1a took place from 11 June to 5 July 2013. Airborne measurements were made by both the ATR-42 and F-20 French research aircraft operated from Sardinia (Italy) and instrumented for in situ and remote-sensing measurements, respectively, and by sounding and drifting balloons, launched in Minorca. The experimental setup also involved several ground-based measurement sites on islands including two ground-based reference stations in Corsica and Lampedusa and secondary monitoring sites in Minorca and Sicily. Additional measurements including lidar profiling were also performed on alert during aircraft operations at EARLINET/ACTRIS stations at Granada and Barcelona in Spain, and in southern Italy. Remote-sensing aerosol products from satellites (MSG/SEVIRI, MODIS) and from the AERONET/PHOTONS network were also used. Dedicated meso-scale and regional modeling experiments were performed in relation to this observational effort. We provide here an overview of the different surface and aircraft observations deployed during the ChArMEx/ADRIMED period and of associated modeling studies together with an analysis of the synoptic conditions that determined the aerosol emission and transport. Meteorological conditions observed during this campaign (moderate temperatures and southern flows) were not favorable to producing high levels of atmospheric pollutants or intense biomass burning events in the region. However, numerous mineral dust plumes were observed during the campaign, with the main sources located in Morocco, Algeria and Tunisia, leading to aerosol optical depth (AOD) values ranging between 0.2 and 0.6 (at $440 \mathrm{~nm}$ ) over the western and central Mediterranean basins. One important point of this experiment concerns the direct observations of aerosol extinction onboard the ATR-42, using the CAPS system, showing local maxima reaching up to $150 \mathrm{M} \mathrm{m}^{-1}$ within the dust plume. Non-negligible aerosol extinction (about $50 \mathrm{Mm}^{-1}$ ) has also been observed within the marine boundary layer (MBL). By combining the ATR42 extinction coefficient observations with absorption and scattering measurements, we performed a complete optical closure revealing excellent agreement with estimated optical properties. This additional information on extinction properties has allowed calculation of the dust single scattering albedo (SSA) with a high level of confidence over the western Mediterranean. Our results show a moderate variability from 0.90 to 1.00 (at $530 \mathrm{~nm}$ ) for all flights studied com- pared to that reported in the literature on this optical parameter. Our results underline also a relatively low difference in SSA with values derived near dust sources. In parallel, active remote-sensing observations from the surface and onboard the F-20 aircraft suggest a complex vertical structure of particles and distinct aerosol layers with sea spray and pollution located within the MBL, and mineral dust and/or aged North American smoke particles located above (up to $6-7 \mathrm{~km}$ in altitude). Aircraft and balloon-borne observations allow one to investigate the vertical structure of the aerosol size distribution showing particles characterized by a large size ( $>10 \mu \mathrm{m}$ in diameter) within dust plumes. In most of cases, a coarse mode characterized by an effective diameter ranging between 5 and $10 \mu \mathrm{m}$, has been detected above the MBL. In terms of shortwave (SW) direct forcing, in situ surface and aircraft observations have been merged and used as inputs in 1-D radiative transfer codes for calculating the aerosol direct radiative forcing (DRF). Results show significant surface SW instantaneous forcing (up to $-90 \mathrm{~W} \mathrm{~m}^{-2}$ at noon). Aircraft observations provide also original estimates of the vertical structure of SW and LW radiative heating revealing significant instantaneous values of about $5^{\circ} \mathrm{K}$ per day in the solar spectrum (for a solar angle of $30^{\circ}$ ) within the dust layer. Associated 3-D modeling studies from regional climate (RCM) and chemistry transport (CTM) models indicate a relatively good agreement for simulated AOD compared with observations from the AERONET/PHOTONS network and satellite data, especially for long-range dust transport. Calculations of the 3-D SW (clear-sky) surface DRF indicate an average of about -10 to $-20 \mathrm{~W} \mathrm{~m}^{-2}$ (for the whole period) over the Mediterranean Sea together with maxima $\left(-50 \mathrm{~W} \mathrm{~m}^{-2}\right)$ over northern Africa. The top of the atmosphere (TOA) DRF is shown to be highly variable within the domain, due to moderate absorbing properties of dust and changes in the surface albedo. Indeed, 3-D simulations indicate negative forcing over the Mediterranean Sea and Europe and positive forcing over northern Africa. Finally, a multiyear simulation, performed for the 2003 to 2009 period and including an ocean-atmosphere $(\mathrm{O}-\mathrm{A})$ coupling, underlines the impact of the aerosol direct radiative forcing on the sea surface temperature, $\mathrm{O}-\mathrm{A}$ fluxes and the hydrological cycle over the Mediterranean.

\section{Introduction}

The Mediterranean region has been identified as one of the most prominent "Hot-Spots" in future climate change projections (Giorgi and Lionello, 2008). It is characterized by its vulnerability to changes in the water cycle (e.g., Chenoweth et al., 2011; García-Ruiz et al., 2011). General circulation model (GCM) and regional climate model (RCM) simulations show a substantial precipitation decrease and a warming of the region, especially in the long warm and dry 
Mediterranean season. At the end of the 21 st century, the average of the model outputs predicts a significant loss of freshwater (40\% for the period 2070-2090 compared to 1950-1999; Sanchez-Gomez et al., 2009) over the Mediterranean region. More recently, Mariotti et al. (2015) have used the newly available Coupled Model Intercomparison ProjectPhase 5 (CMIP5) experiments and show a significant increase in the projected surface air temperature (by $\sim+2-$ $3{ }^{\circ} \mathrm{C}$ ) for the 2071-2098 period compared to 1980-2005. These results need to be put in the context of an increasing anthropogenic pressure on the Mediterranean region, with an expected doubling of the population in countries around the Mediterranean basin in the next decades, with a contrast between a small decrease in European countries and a strong increase in African and Middle Eastern countries (Brauch, 2003). However, as highlighted by Mariotti et al. (2008), despite the high degree of model consistency, the results regarding the future climate projections for the Mediterranean Sea water budget from the global coupled models are still uncertain due to their horizontal spatial resolutions that are not capable of resolving the local to regional Mediterraneanspecific processes (air-sea exchanges, coastline, topography, north-south gradient of surface albedo). Indeed, the Mediterranean climate is affected by local processes induced by the complex physiography of the region and the presence of a large body of water (the Mediterranean Sea). For example, the Alpine chain is a strong factor in modifying traveling synoptic and mesoscale systems and the Mediterranean Sea is an important source of moisture and precipitation in the region (Gimeno et al., 2010; Schicker et al., 2010) and of energy for storms (Lionello et al., 2006). The complex topography, coastline and vegetation cover of the region are well known to modulate the regional climate signal at small spatial scales (e.g., Millán et al., 1997; Gangoiti et al., 2001; Lionello et al., 2006).

So far, most global and regional climate simulations have investigated the impact of global warming on the Mediterranean climate without detailed considerations of the possible radiative influence and climatic feedback from the different Mediterranean aerosols (anthropogenic, marine, biomass burning, secondary biogenic and mineral dust particles). The Mediterranean region is rich in a variety of particles (natural and anthropogenic) from both continental and marine sources (Lelieveld et al., 2002). In Fig. 1, we illustrate the significant differences in aerosol loading between the eastern, central, and western sub-basins and between the north and the south of the Mediterranean shown by long-term aerosol satellite products. The aerosol optical depth (AOD), which represents the integration of the extinction by particles along the whole atmospheric column, displays annual mean values (Fig. 1) from 0.2 to 0.5 (in the visible wavelengths), depending on the aerosol types observed over the Euro-Mediterranean region (Nabat et al., 2013).

Numerous studies have documented the AOD for polluted anthropogenic Mediterranean aerosols at a local scale over southeastern France (Mallet et al., 2006; Roger et al., 2006), Spain (Horvath et al., 2002; Alados-Arboledas et al., 2003, 2008), the western Mediterranean (Lyamani et al., 2015), Greece (Chazette and Liousse, 2001; Gerasopoulos et al., 2003), the Greek island of Crete (Fotiadi et al., 2006), and Italy (Tafuro et al., 2007; Ciardini et al., 2012). Under polluted conditions, they report low to moderate AOD values ranging between 0.1 and 0.5 (at visible wavelengths). In parallel, multi-year TOMS and MODIS observations over the eastern Mediterranean (Hatzianastassiou et al., 2009) or the Po Valley (Royer et al., 2010) indicate the occurrence of high AOD values (up to more than 0.8 at $500 \mathrm{~nm}$ ) over large urban areas surrounding megacities.

Numerous studies (Markowicz et al., 2002; Ravetta et al., 2007; Liu et al., 2009; Kaskaoutis et al., 2011; Barnaba et al., 2011; Amiridis et al., 2012; Baldassarre et al., 2015) have also been dedicated to biomass burning aerosols over the Mediterranean, which are mainly observed in July and August (driest months of the year), when the development of forest fires is favored (Pace et al., 2005). Long-term observations of absorbing aerosols have clearly shown the major role of long-range transport of biomass (agriculture waste) burning in the eastern Mediterranean (Sciare et al., 2008). AOD data available for smoke particles show "intermediate" values between those observed for dust and anthropogenic particles. For example, AOD values ranging between 0.3 and 0.8 (Pace et al., 2005) have been observed at Lampedusa from 5 to 22 August 2003, in relation to intense fires developed in southern Europe and transported over the Mediterranean basin during a regional heat wave. In addition, the STAAARTE-MED experiment (August 1998 in the eastern Mediterranean) has also documented a mean AOD of 0.39 (at $550 \mathrm{~nm}$ ) for aged smoke plume from Canadian fires (Formenti et al., 2002). This kind of long-range transport has also been observed over the western Mediterranean (OrtizAmezcua et al., 2014).

Concerning natural aerosols, different cases of Saharan mineral dust have been regularly documented with local optical measurements on the island of Lampedusa by Meloni et al. (2003, 2004), who indicate moderate AOD (at $415.6 \mathrm{~nm}$ ) of about $0.23-0.26$ and one significantly larger event with AOD values of 0.51. Meloni et al. (2008) also report AOD (at $500 \mathrm{~nm}$ ) measurements ranging between 0.29 and 1.18 for the 1999 to 2006 period. For some extreme cases, dust AOD peaks may be even larger, reaching values up to 2 as observed by di Sarra et al. (2011). In parallel to Lampedusa observations, Kubilay et al. (2003) have also documented three dust intrusion events at Erdemli (Turkish coast), occurring in spring from the central Sahara, in summer from the eastern Sahara, and in the fall from the Middle East/Arabian Peninsula. In each case, the presence of dust particles significantly increased the AOD, up to 1.8. Over the western Mediterranean, different studies also reveal the impact of Saharan dust that occasionally can lead to extreme events with AOD (at $500 \mathrm{~nm}$ ) above 1 (Guerrero-Rascado et al., 2009). 


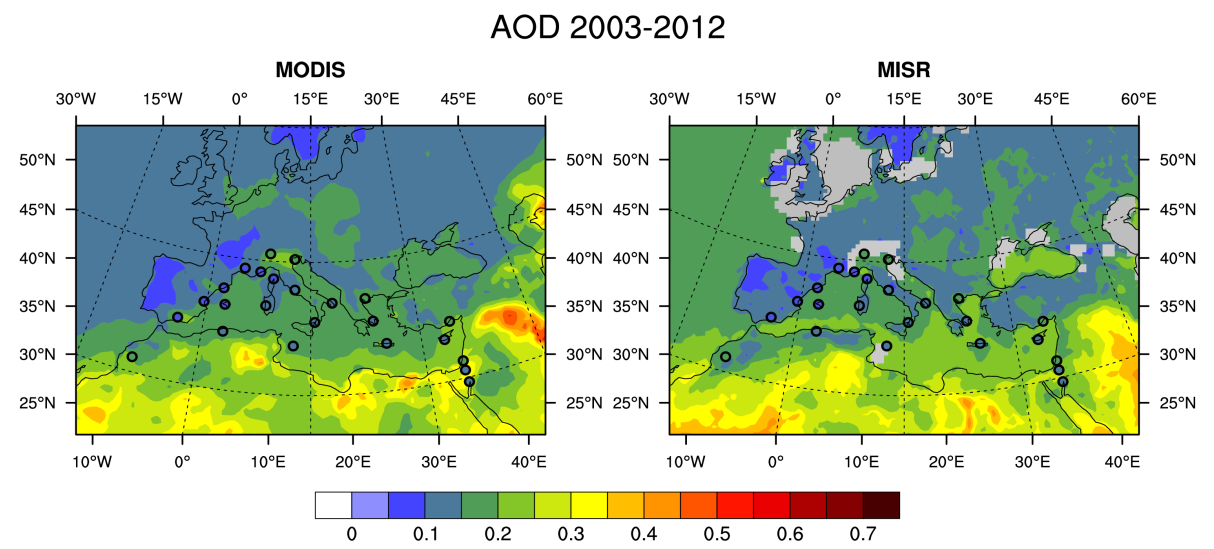

Figure 1. Aerosol optical depth (at $550 \mathrm{~nm}$ ) derived from the MODIS and MISR satellites for the 2003 to 2012 period. The AERONET/PHOTONS AOD is also indicated (in small circles).

For sea-spray particles, which are the second main natural species observed over the Mediterranean, Nabat et al. (2013) report a relatively low monthly mean AOD derived from satellites and modeling data, with values lower than 0.05 (in the visible wavelengths). By using recent improvements in the sea-spray emission scheme, Spada et al. (2013) show an averaged sea-spray AOD of around 0.04 for the month of January (5-year period, 2002-2006), which is the favorable period for generating primary sea spray due to strong sea surface winds. Finally, and in the case of extreme wind episodes occurring over the western basin, Salameh et al. (2007) show that the amount of aerosol loading, solely due to the Mistral, Tramontane and Ligurian outflows, is as large as 3-4 times the background aerosol amount. They indicate that the contribution of sea-spray particles to the total aerosol loading and optical depth ranges from 1 to $10 \%$. Salameh et al. (2007) report AOD around $0.15-0.20$ (at $865 \mathrm{~nm}$ ) within the sea-spray aerosol plume during such strong wind events. In addition, Mulcahy et al. (2008) reported a high correlation between AOD and wind speed, with AOD values of 0.3-0.4 at moderately high wind speed.

In addition to AOD, the knowledge of SSA is essential for estimating the aerosol direct and semi-direct radiative forcing. Concerning mineral dust particles observed over the Mediterranean, it should be noted that significant variations in SSA are reported, with values near 1 for purely scattering aerosols, and quite remarkable low values $(0.74,0.77$ or 0.81) at Lampedusa (Pace et al., 2006; Meloni et al., 2003). At the high-altitude Alpine Jungfraujoch station, SSA values are generally higher than 0.9 in the case of African dust, but occasional SSA as low as $0.75-0.80$ is reported by Collaud Coen et al. (2004). Intermediate values (0.85-0.92) have also been reported over the Mediterranean basin (Kubilay et al., 2003; Meloni et al., 2004; Saha et al., 2008). These estimates clearly indicate that significantly different SSA values are obtained following the dust particle origins and/or possible mixing of mineral dust with other species. For example,
Kubilay et al. (2003) underlined the importance of mixing, showing SSA values clearly lower $(0.85-0.90)$ in the case of mineral dust transport coincident with urban-industrial aerosols, as compared to pure dust (0.96-0.97).

In addition, SSA observed in the case of urban/industrial regimes has also been well documented over the Mediterranean Sea and coastal regions. In most cases, moderate or low SSA (0.78-0.94) is observed due to emissions containing absorbing black carbon aerosols. Over southeastern France, optical computations performed by Mallet et al. (2004) and Saha et al. (2008) indicate SSA values of 0.85 and 0.83 (at $550 \mathrm{~nm}$ ) near the cities of Toulon and Marseilles, respectively. Aircraft observations performed over the Marseilles/Etang de Berre area during the ESCOMPTE campaign show values ranging between 0.88 and 0.93 (at $550 \mathrm{~nm}$ ) in the planetary boundary layer (PBL) (Mallet et al., 2005). These SSA values are close to those observed in southern Spain (0.86-0.90) by Horvath et al. (2002). Over southeastern Italy, Tafuro et al. (2007) reported a value of 0.94 during summertime corresponding to anthropogenic particles. Finally, polluted particles transported over the Mediterranean basin also have relatively low values as reported by Markowicz et al. (2002) over Crete (0.87) and by Di Iorio et al. (2003) (0.79-0.83) over Lampedusa for two cases (25 and 27 May 1999) of "aged" anthropogenic aerosols originating from Europe.

As opposed to dust and polluted aerosols, few studies have derived the biomass burning SSA over the Mediterranean Sea. One estimate has been obtained during STAAARTEMED by Formenti et al. (2002), who reported a mean dry SSA of 0.89 (at $500 \mathrm{~nm}$ ) for aged smoke from North America. Meloni et al. (2006) report estimations at Lampedusa with values of $0.82 \pm 0.04$ (at $415 \mathrm{~nm}$ ) for smoke aerosols over the Mediterranean region. The observed differences between SSA values could be due to the fact that the smoke events described by Meloni et al. (2006) are more "local" and not (or somewhat less) mixed with other secondary 
species, as compared to biomass burning particles documented by Formenti et al. (2002), which were issued from very distant Canadian fires. Finally, at Palencia (Spain), Cachorro et al. (2008) reported a column-integrated SSA of 0.88 (at $440 \mathrm{~nm}$ ) for a biomass burning event occurring in 28 July 2004. One should remember that most estimations of SSA over the Mediterranean have been obtained from surface in situ or remote-sensing techniques. In that sense, the ChArMEx/ADRIMED project provides innovative observations of 3-D aerosol SSA, allowing investigating changes in its optical property during the transport of aerosols over the Mediterranean.

Concerning the aerosol vertical profiles and apart from a few airborne in situ measurements (Formenti et al., 2002), most of the available information in the Mediterranean region comes from lidar observations, which provide highly resolved vertical profiles of aerosol backscattering at one or more wavelengths and, depending on the complexity of the instrumental setup, particles depolarization and extinction. Several sites are equipped with aerosol lidar systems and carry out regular observations in a coordinated way within EARLINET (European Aerosol Research Lidar Network; Pappalardo et al., 2014; Wang et al., 2014). Numerous studies have been specifically dedicated to the vertical distribution of Saharan dust during extended time periods and/or selected events from various Mediterranean regions, mainly from ground-based systems: (i) the eastern basin in Thessaloniki (Hamonou et al., 1999; Balis et al., 2004), Crete (Balis et al., 2006), the Aegean Sea (Dulac and Chazette, 2003), and Athens plus Thessaloniki (Papayannis et al., 2005; Balis et al., 2006); (ii) the central basin in Lampedusa (Di Iorio et al., 2003; Meloni et al., 2004), Lecce (Tafuro et al., 2006), and at Etna (Tafuro et al., 2006); and (iii) across the western basin with the first spaceborne lidar (Berthier et al., 2006) and at Observatoire de Haute Provence (Hamonou et al., 1999), and Barcelona (Pérez et al., 2006; Sicard et al., 2011). Finally, using data from 20 EARLINET lidar stations, Papayannis et al. (2008) indicate that African dust transport over the Mediterranean basin is layered. Their analysis confirms early observations by Hamonou et al. (1999) that not only different dust layers are superimposed at different altitudes, but that these layers have different source regions. The dust layers were generally detected between 1.8 and $9 \mathrm{~km}$ altitude.

Not only desert dust, however, can be transported above the marine atmospheric boundary layer. Balis et al. (2004) report non-dust aerosols within elevated layers over Thessaloniki, and Formenti et al. (2002) report a forest fire haze layer from Canada observed from airborne measurements between approximately 1 and $3.5 \mathrm{~km}$ above the northeastern Mediterranean in August 1998. Pérez et al. (2004) describe the complex interaction among orography, sea breeze and pollution that causes the recirculation of pollutants and produces a strong layering with pollution aerosol layers above the boundary layer in the region of Barcelona. In addition, aerosol plumes are emitted sporadically in the Mediterranean free troposphere by Etna volcano. Such plumes have been observed to travel at altitudes between 4 and $5 \mathrm{~km}$ (Pappalardo et al., 2004) or above (Sellitto et al., 2015) at a relatively short distance from Etna. To summarize, the lidar observations clearly show that only part of the aerosol transport occurs in the MBL demonstrating the need of using aircraft observations within the aerosol plume to determine the aerosol microphysical-chemical and optical properties of particles transported in altitude and so not detectable at the surface. Indeed, although lidar observations provide obviously crucial information on the aerosol vertical profiles, most of lidar systems cannot derive information on the aerosol size distribution, optical properties and chemical composition along the vertical. Such observations can only be obtained using in situ aircraft vertical profiles as proposed in this ChArMEx/ADRIMED experiment. As an example, this project provides interesting and unique observations of 3-D aerosol size distribution during the transport over the Mediterranean basin, allowing one to investigate changes in size distribution between mixed and pure mineral dust.

In terms of radiative effects, such atmospheric aerosol characteristics (loadings, absorbing properties, vertical layering) are known (Nabat et al., 2012; Papadimas et al., 2012; Zanis et al., 2012) to significantly change the radiative budget of the Mediterranean region by (1) decreasing the sea surface incoming shortwave radiations, (2) increasing/decreasing outgoing shortwave fluxes depending on the surface albedo and (3) possibly heating turbid atmospheric layers when particles absorb solar light. This is the so-called aerosol direct radiative forcing (DRF). As for the AOD, many aerosol DRF calculations are now referenced over the Mediterranean, clearly showing that the DRF is significantly larger at daily timescales than the one exerted by the additional anthropogenic greenhouse gases.

Concerning polluted aerosols, shortwave DRF has been estimated by many authors (Horvath et al., 2002; Markowicz et al., 2002; Meloni et al., 2003; Mallet et al., 2006; Roger et al., 2006; Saha et al., 2008; di Sarra et al., 2008; Di Biagio et al., 2009, 2010). Studies show significant decreases of surface solar fluxes of about $20-30 \mathrm{~W} \mathrm{~m}^{-2}$ (daily mean) for different locations such as Almeria (southern Mediterranean coast of Spain), Finokalia (Crete), Lampedusa, Marseilles and Toulon (southeastern France). In parallel, the combination of surface and satellite remote-sensing observations performed at Lampedusa has been used to perform calculations of the DRF, both in the shortwave (SW; Di Biagio et al., 2010) and longwave (LW; di Sarra et al., 2011; Meloni et al., 2015) spectral regions for different cases of Saharan dust intrusions. These studies emphasize that the radiative effect of desert dust in the LW spectral range is significant, and offsets a large fraction of the SW forcing (di Sarra et al., 2011; Meloni et al., 2015). More recently, Sicard et al. (2014a, b) have also produced estimations of the dust LW radiative effect, 
based on remote-sensing observations in Barcelona and 1-D radiative transfer calculations.

Concerning the smoke DRF, some calculations have been conducted over the Mediterranean region by Markowicz et al. (2002), di Sarra et al. (2008), Kaskaoutis et al. (2011) or Formenti et al. (2002). One estimate, proposed by Formenti et al. (2002) for an aged Canadian biomass-burning plume, reveals a significant SW surface dimming of about $\sim$ $60 \mathrm{~W} \mathrm{~m}^{-2}$. In addition, the DRF induced by smoke aerosols at Lampedusa between 3 and 23 August 2003, during the exceptionally hot and dry season, was derived by Pace et al. (2005) for the 300-800 nm spectral range. The smoke atmospheric forcing was estimated to be between +22 and $+26 \mathrm{~W} \mathrm{~m}^{-2}$, with a corresponding SW heating rate possibly exceeding $2 \mathrm{Kd}^{-1}$ at the smoke plume altitude.

At the regional scale, Papadimas et al. (2012) have proposed a recent estimation of the aerosol DRF using MODIS data from 2000 to 2007 for both all-sky and clear-sky conditions. They derived a multi-year regional mean surface of $-19 \mathrm{~W} \mathrm{~m}^{-2}$, associated with a TOA DRF of $-4.5 \mathrm{Wm}^{-2}$. Regional modeling studies have also been recently proposed by Nabat et al. (2012, 2014, 2015a) using the coupledchemistry RegCM and CNRM-Regional Climate System Model (RCSM) for multi-year simulations. These works reported a mean regional surface (TOA) forcing of about $-12 \mathrm{Wm}^{-2}\left(-2.4 \mathrm{~W} \mathrm{~m}^{-2}\right)$ and $-16 \mathrm{~W} \mathrm{~m}^{-2}\left(-5.7 \mathrm{Wm}^{-2}\right)$ for the RegCM and CNRM-RCSM models, respectively. RegCM has also been used to investigate direct and semidirect radiative effects of mineral dust over the Sahara and Europe in a test case of July 2003 (Santese et al., 2010). In this work, Santese et al. (2010) computed a daily mean SW DRF of $-24 \mathrm{Wm}^{-2}\left(-3.4 \mathrm{Wm}^{-2}\right)$ on 17 July and $-25 \mathrm{~W} \mathrm{~m}^{-2}\left(-3.5 \mathrm{~W} \mathrm{~m}^{-2}\right)$ on 24 July at the surface (TOA) on average over the simulation domain. Zanis et al. (2012) also proposed a regional estimate of the DRF of anthropogenic particles over the 1996-2007 period using RegCM and showed a significant forcing of up to $-23 \mathrm{~W} \mathrm{~m}^{-2}$ at TOA over eastern Europe. In addition, Péré et al. (2011) have used the CTM-CHIMERE model coupled to the WRF model, for estimating the DRF of anthropogenic particles during the heat wave of summer 2003 and showed significant effects with implications on the planetary boundary layer height (decrease up to $30 \%$ in the presence of anthropogenic aerosols) and local air quality. In addition to their important effects on the surface and TOA DRF, most of the Mediterranean aerosols are also able to absorb more or less effectively the solar radiations leading to a significant atmospheric forcing and associated SW heating rate. Local studies previously mentioned (Roger et al., 2006; Saha et al., 2008; Pace et al., 2005; Péré et al., 2011; Meloni et al., 2015) clearly report significant SW heating rate due to absorbing particles with values reaching up to $2-3 \mathrm{~K}$ per day, depending on the aerosol types. Finally, aerosols also have a significant effect on photolysis rates that may affect tropospheric chemistry and ozone production over the basin (Casasanta et al., 2011; Mailler et al., 2015).

With regards to such surfaces, TOA and atmospheric forcings, there is a need to investigate how the change in the radiative budget due to natural/anthropogenic aerosols influences surface temperature (both over land and sea), relative humidity profiles, exchanges (latent heat fluxes) between ocean and atmosphere, cloud cover (semi-direct effect of absorbing particles), precipitation and finally the whole Mediterranean hydrological cycle. The induced perturbations in the sea surface-atmosphere fluxes is expected to be important despite the relatively small size of the Mediterranean Sea, since this basin plays an important role at much larger scale by providing moisture for precipitation to its surroundings land region extending to northern Europe and northern Africa (Gimeno et al., 2010; Schicker et al., 2010). Indeed, and as shown by Ramanathan et al. (2001) for the Indian region or Foltz and McPhaden (2008) and Yue et al. (2011) for the Atlantic Ocean, a modification of the sea surface evaporative fluxes, due to the dimming radiative effect of aerosols at the sea surface could significantly influence the lower troposphere moisture content and the associated precipitation distribution around the Mediterranean. In parallel, the absorbing particles over the Mediterranean (Mallet et al., 2013) could exert a semi-direct effect that could modify the vertical profiles of relative humidity and cloud cover, which has to be quantified. To our knowledge, there is no regional climate simulation over the Mediterranean basin at this time that includes an ocean-atmosphere (O-A) coupled system model for investigating this specific question.

In that context of the referenced modeling and observation research over the Mediterranean basin, the main objectives of the ChArMEx/ADRIMED project were the following:

- to conduct an experimental campaign, based on surface and aircraft observations, for creating a rich 3-D database of physical, chemical and optical properties of the main Mediterranean aerosols, including (i) original in situ aircraft observations of extinction coefficients, size distribution, black carbon concentrations as well as (SW and LW) radiative fluxes and associated heating rates, (ii) balloons observations of aerosol size distribution and (iii) surface measurements including original characterization of chemical properties

- to investigate how the aerosol size distribution and optical (especially SSA) properties evolve along the verti$\mathrm{cal}$, between the MBL and elevated layers, and during the transport over the Mediterranean

- to use experimental surface and aircraft observations to estimate the 1-D local DRF and forcing efficiency of different aerosols at the surface, TOA and within the atmospheric layer

- to investigate how the modifications of the radiative budget due to aerosols affect the sea surface evaporation 
fluxes, relative humidity profiles, cloud cover, precipitation and more largely the Mediterranean hydrological cycle

The present article describes the experimental setup of the campaign and the meteorological context and illustrates important results detailed in a series of companion papers. The rest of this article is divided into six different parts. In the first and second parts (Sects. 2 and 3 ), we describe the in situ and remote-sensing instrumentation deployed at the two super-sites (Ersa and Lampedusa) and secondary sites (Minorca, Capo Granitola and the Barcelona and Granada EARLINET/ACTRIS stations), the additional AERONET/PHOTONS (AErosol RObotic NETwork/PHOtométrie pour le Traitement Opérationnel de Normalisation Satellitaire, http://aeronet.gsfc.nasa.gov/; Holben et al., 1998) and EARLINET/ACTRIS (European Aerosol Research Lidar Network/Aerosols, Clouds, and Trace gases Research InfraStructure Network, http://www. actris.net/; Pappalardo et al., 2014) network stations that we used, and the airborne observations obtained onboard the two French research aircraft (ATR-42 and F-20) and with sounding and drifting balloons. Sect. 4 is dedicated to presenting the main meteorological conditions, cloud cover and precipitation, which controlled the aerosol emission and transport during the period of observations. Sect. 5 presents some examples of results concerning the in situ and remote-sensing observations, in terms of aerosol physical, chemical, optical properties, and vertical profiles, as well as 1-D DRF SW and LW calculations. In the last part (Sect. 6), the modeling effort is presented. Different models are involved in this project, from high-resolution meteorological and chemistry transport models to regional climate models. The modeling results are used to describe the anthropogenic (carbonaceous, secondary inorganic and organic species) and natural (dust and sea-spray) loading and the estimated DRF at the regional scale for the period of experiment. An example of results of longer (inter-seasonal and inter-annual) aerosol-climate simulations is presented in Sect. 6, based on the work of Nabat et al. (2015a).

\section{Overview of the surface observation network}

The regional experimental setup deployed in the western and central Mediterranean during the ChArMEx SOP-1a campaign is shown in Fig. 2. Two super-sites (Cape Corsica and Lampedusa) and 10 secondary sites (Fig. 2) have been used in this project.

\subsection{The Cape Corsica and Lampedusa surface super-sites}

Two super-sites were fully equipped for documenting the aerosol chemical, physical and optical properties as well as their possible mixing and their vertical structure at local scale

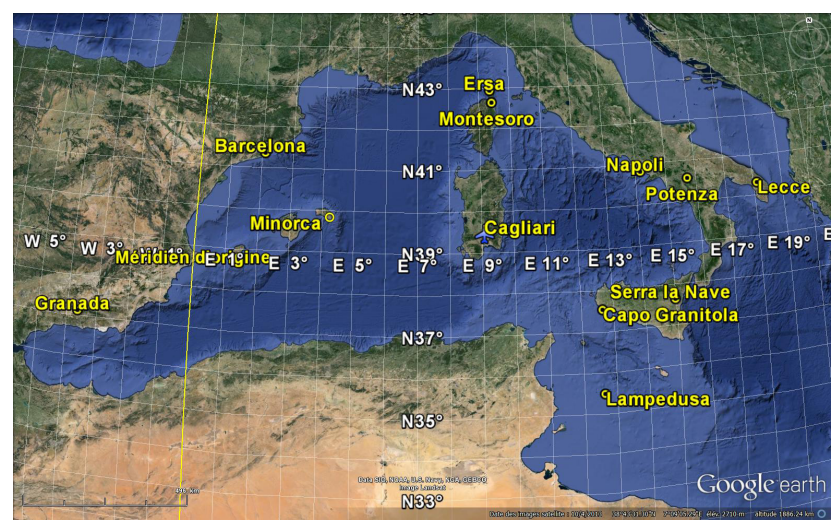

Figure 2. The regional experimental setup deployed in the western and central Mediterranean during the ChArMEx SOP-1a campaign. The two aircraft were based at Cagliari.

(Table 1). The main characteristics of these two surface stations are presented here. The first station was located in Ersa on Cape Corsica $\left(42^{\circ} 58^{\prime} 10^{\prime \prime} \mathrm{N}, 9^{\circ} 22^{\prime} 49^{\prime \prime} \mathrm{E}\right)$, near the northern tip of Corsica. This station was primarily instrumented for investigating polluted air masses transported over the Mediterranean basin from the highly industrialized regions of the Po Valley (Royer et al., 2010) and/or the MarseilleFos-Berre (Cachier et al., 2005) zone and Rhone Valley. This ground-based remote station is located at an altitude of about $530 \mathrm{~m}$ above mean sea level (a.m.s.1.) on a ridge equipped with windmills and benefits from a direct view to the sea over a northern sector of $\sim 270^{\circ}$ extending from the SW to the SE. The Cape Corsica peninsula is a remote site ensuring that the in situ measurements are not contaminated by local anthropogenic pollution.

The Lampedusa super-site $\left(35^{\circ} 31^{\prime} 5^{\prime \prime} \mathrm{N}, 12^{\circ} 37^{\prime} 51^{\prime \prime} \mathrm{E}\right)$ was established at the Roberto Sarao station permanently operated by ENEA on the small island of Lampedusa $\left(\sim 20 \mathrm{~km}^{2}\right)$, and it was augmented during the field campaign by the observations of the PortablE Gas and Aerosol Sampling UnitS (PEGASUS) mobile station operated by LISA. This surface station was mainly used for documenting very aged air masses in southwesterly flow from Europe, southern air masses from northern Africa (Tunisia, Algeria and Libya) possibly laden with mineral dust, as well as marine aerosols. It is situated on a cliff at about $45 \mathrm{~m}$ a.m.s.l. on the northeastern tip of the island.

The complete instrumentation deployed during the SOP1a experiment for both super-sites is detailed in Table 1. Briefly, it served to determine the complete aerosol physical, chemical and optical properties as well as vertical profiles, and to measure radiative fluxes (broadband SW and LW, and spectral SW). 


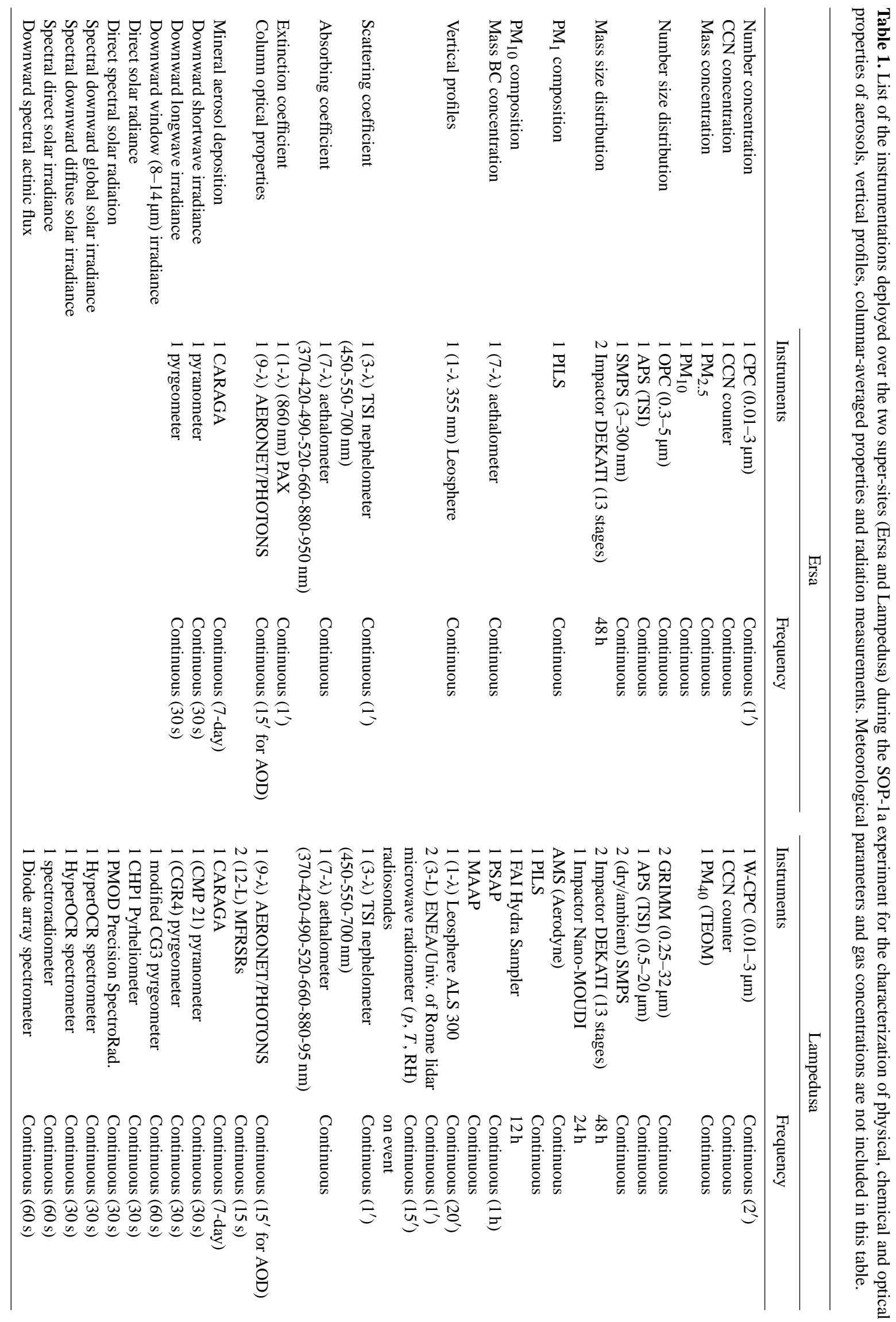




\subsubsection{In situ measurements at super-sites}

Both super-sites measured the mass concentration online using tapered element oscillating microbalance (TEOM) analyzers. The number size distribution of particles are also measured, including fine and coarse fractions (radius ranges and corresponding instruments are reported in Table 1). The aerosol composition was derived from chemical analyses of filters and cascade impactors (DEKATI and MOUDI) with time resolution varying from 12 to $48 \mathrm{~h}$ (depending on the aerosol load), but also from high time resolution online measurements by an ACSM (Aerosol Chemical Speciation Monitor) at Ersa, a C-TOF-AMS (Time of Flight Aerosol Mass Spectrometer) at Lampedusa, and two PILS (Particle Into Liquid Sampler) systems at both sites (Table 1). The original observations of aerosol chemical properties obtained from PM10-PILS instrument at Ersa are detailed in Claeys et al. (2016). Concerning aerosol optical properties, scattering and absorption coefficients (at wavelengths listed in Table 1) have been estimated for both super-sites using a 3- $\lambda$ nephelometer and a 7- $\lambda$ aethalometer, respectively. At Ersa station, the extinction coefficient (at $870 \mathrm{~nm}$ ) was also estimated using a Photoacoustic Extinctiometer (PAX) instrument, while it has been estimated at $2-\lambda(450$ and $630 \mathrm{~nm})$ at Lampedusa using two Cavity Attenuated Phase Shift Spectroscopy (CAPS) systems.

Additional in situ measurements were performed at the Ersa station. The mixing state of fine particles (at the two selected diameters of 50 and $110 \mathrm{~nm}$ in dry conditions) has also been estimated from their hygroscopic behavior using a VHTDMA (volatilization and humidification tandem differential mobility analyzer) system (Johnson et al., 2004). In parallel, a TSI (model 3800) aerosol time of flight mass spectrometer (ATOFMS) (Gard et al., 1997) was used to measure the size-resolved chemical composition of single particles in the vacuum aerodynamic diameter $\left(d_{\mathrm{va}}\right)$ size range 100 $3000 \mathrm{~nm}$.

\subsubsection{Remote-sensing and radiation measurements at super-sites}

A Leosphere Raman lidar model RMAN510 was setup at low altitude ( $\sim 11 \mathrm{~m}$ above sea level) in the small village of Macinaggio $\left(42^{\circ} 57^{\prime} 44^{\prime \prime} \mathrm{N}, 9^{\circ} 26^{\prime} 35^{\prime \prime} \mathrm{E}\right)$ located on the eastern coast of Cape Corsica. The lidar was operated at about $6 \mathrm{~km}$ east of the Ersa station and less than $700 \mathrm{~m}$ from the shoreline. The RMAN510 uses a laser emitting at $355 \mathrm{~nm}$. It measures the total and polarized backscatter at $355 \mathrm{~nm}$ and the Raman nitrogen signal at $387 \mathrm{~nm}$ at night-time. A second ALS300 510 lidar system has been deployed in Lampedusa (Formenti et al., 2016) as well as a more powerful University of Rome-ENEA homemade lidar measuring backscatter at 532 and $1064 \mathrm{~nm}$ (Di Iorio et al., 2016). The main characteristics of lidar systems are provided and detailed in Table 1.
At each station, a multi-wavelength sun-photometer from the AERONET/PHOTONS network was operated, allowing the operational retrieval of column-integrated AOD at 340, $380,440,500,675,870$, and $1020 \mathrm{~nm}$ (and also at $1650 \mathrm{~nm}$ at Ersa) and aerosol optical and microphysical properties such as the single scattering albedo, refractive index and particle size volume distribution (Dubovik and King, 2000; Dubovik et al., 2000, 2002, 2006). The Ersa sun-photometer has been positioned since June 2008 near the navy semaphore on the northwestern tip of Cape Corsica $\left(43^{\circ} 00^{\prime} 13^{\prime \prime} \mathrm{N}, 9^{\circ} 21^{\prime} 33^{\prime \prime} \mathrm{E}\right.$, alt. $\sim 75 \mathrm{~m}$ a.m.s.1.) at about $4.2 \mathrm{~km} \mathrm{NNW}$ of the Ersa surface station.

Both super-sites were complemented by a pyrgeometer and a pyranometer for monitoring longwave and shortwave downward fluxes measurements, respectively. Additional radiation measurements were performed at Lampedusa (Table 1). Spectral measurements of global, diffuse, and direct radiation were carried out with other instruments deployed by ENEA and the Physikalisch-Meteorologisches Observatorium Davos, World Radiation Center (PMOD/WRC, Switzerland). Multi-filter rotating shadowband radiometer observations were carried out jointly with AERONET sunphotometer (di Sarra et al., 2015) and allowed the derivation of the AOD at several wavelengths. By combining these two measurements, a long-term series of AOD, started in 2001, was obtained. Measurements of the spectral actinic flux, allowing the determination of the photolysis rates (Mailler et al., 2015), were carried out with a diode array spectrometer. Measurements of broadband irradiance included a CG3 pyrgeometer sensitive to radiation in the atmospheric infrared window. Finally, the total ozone and spectral UV irradiance were obtained with a Brewer spectrophotometer. Several radiosondes were also launched from Lampedusa during the SOP-1a, and vertical profiles of temperature and humidity were continuously measured by a microwave radiometer.

\subsection{The secondary sites}

\subsubsection{Montesoro station}

The Cape Corsica station was complemented by an additional remote-sensing setup at the peri-urban air quality station of Montesoro, southward of Bastia at about $45 \mathrm{~m}$ a.m.s.l. (Léon et al., 2015), including a Leosphere model EZ lidar operating at $355 \mathrm{~nm}\left(42^{\circ} 40^{\prime} 17^{\prime \prime} \mathrm{N}\right.$, $\left.9^{\circ} 26^{\prime} 05^{\prime \prime} \mathrm{E}\right)$ and a Cimel AERONET/PHOTONS sunphotometer $\left(42^{\circ} 40^{\prime} 19^{\prime \prime} \mathrm{N}, 9^{\circ} 26^{\prime} 06^{\prime \prime} \mathrm{E}\right)$. In addition, some airquality parameters were monitored by Qualitair Corse, including $\mathrm{PM}_{2.5}$ and $\mathrm{PM}_{10}$. This station is less than $1 \mathrm{~km}$ from the shore on the northeastern coast of Corsica, about $32 \mathrm{~km}$ south of Macinaggio. 


\subsubsection{Barcelona station}

The Barcelona station $\left(41.39^{\circ} \mathrm{N}, 2.11^{\circ} \mathrm{E}, 115 \mathrm{~m}\right.$ a.m.s.l.) was equipped with the following fixed instruments including an AERONET sun-photometer, an automated Sigma SpaceNASA Micro Pulse Lidar (MPL) and a Universitat Politècnica de Catalunya (UPC) home-made multi-wavelength lidar (Kumar et al., 2011). The MPL lidar works at $532 \mathrm{~nm}$ and has a depolarization channel, while the UPC lidar works at 355,532 and $1064 \mathrm{~nm}$, and also includes two $\mathrm{N}_{2-}$ (at 387 and $607 \mathrm{~nm}$ ) and one $\mathrm{H}_{2} \mathrm{O}$-Raman (at $407 \mathrm{~nm}$ ) channels. The MPL system worked continuously. The UPC system was operated on alert in coordination with the two research aircraft plans involved in the SOP-1a campaign. The UPC system is part of the EARLINET network.

\subsubsection{Minorca station}

An additional station was set up during the campaign, located at Cap d'en Font, on the southeastern coast of the Balearic Island of Minorca (Spain, 39 $53^{\prime} 12^{\prime \prime} \mathrm{N}$ and $4^{\circ} 15^{\prime} 31^{\prime \prime} \mathrm{E}, \sim 10 \mathrm{~m}$ a.m.s.l.), which is relatively central in the western Mediterranean basin. The Mobile Aerosol Station (MAS) of the LSCE (Laboratoire des Sciences du Climat et de l'Environnement) laboratory was equipped with the new Raman lidar WALI (Chazette et al., 2014a, b), an AERONET/PHOTONS sun-photometer, and a set of in situ instruments. A five-wavelength Solar Light MicrotopsII manual sun-photometer was also used. The WALI instrument, its calibration and the associated errors are documented in Chazette et al. (2014a). During all the experiment, the acquisition was performed continuously with a vertical resolution of $15 \mathrm{~m}$. AOD at the lidar wavelength of $355 \mathrm{~nm}$ has been extrapolated from that measured by sun-photometer at 380 and $440 \mathrm{~nm}$ using the Angström exponent (Chazette et al., 2015).

The in situ instruments installed onboard the MAS included a three-wavelength TSI nephelometer, a Magee Scientific Model AE31 seven-wavelength aethalometer, a TEOM microbalance, and a Vaisala meteorological probe type PTU300. The nephelometer was sampling through a $\mathrm{PM}_{10}$ inlet to measure the aerosol scattering coefficient at three wavelengths $(450,550$ and $700 \mathrm{~nm})$ with an integrating time step of $5 \mathrm{~min}$. The aethalometer was sampling through a $\mathrm{PM}_{2.5}$ inlet to measure aerosol absorption (at seven wavelengths) and derive a 5 min average black carbon concentration. The TEOM measured dry $\mathrm{PM}_{10}$ concentration every $30 \mathrm{~min}$. In addition two optical particle counters (OPCs) were installed outdoors next to the sun-photometer on a mobile platform. A MetOne HHPC-6 and a LOAC (Renard et al., 2015a, b), respectively, measured aerosol particle number concentration in 6 channels above $0.3 \mu \mathrm{m}$ in diameter and in 19 channels above $0.2 \mu \mathrm{m}$. The LOAC instrument accuracy is discussed in detail by Renard et al. (2015a, b).

\subsubsection{Granada station}

The station of the Atmospheric Physics Group (GFAT) is located in the Andalusian Institute for Earth System Research (IISTA-CEAMA), in Granada, Spain $\left(37.16^{\circ} \mathrm{N}\right.$, $3.61^{\circ} \mathrm{W}, 680 \mathrm{~m}$ a.m.s.l.). The station is at a relatively short distance, about $200 \mathrm{~km}$ away, from the African continent and approximately $50 \mathrm{~km}$ away from the western Mediterranean Sea. During the SOP-1a campaign, lidar measurements were performed simultaneously with a multiwavelength Raman lidar and a scanning Raman lidar both from Raymetrics S.A. The multi-wavelength Raman system is part of the EARLINET network. In addition, a ceilometer was operated. Column integrated characterization of the atmospheric aerosol was performed following AERONET protocols with two Cimel sun-photometers deployed at two different heights: Granada (680 ma.s.l.) and Cerro Poyos $\left(37^{\circ} 6^{\prime} 32^{\prime \prime} \mathrm{N}, 3^{\circ} 29^{\prime} 14^{\prime \prime} \mathrm{W}, 1790 \mathrm{~m}\right.$ a.s.l.) stations. In addition, in situ instrumentation was continuously operated providing measurements of aerosol light-absorption coefficient at multiple wavelengths (multi-angle absorption photometer (MAAP) from Thermo ESM Andersen Instruments and Aethalometer model AE31), size distribution and particle number concentration for diameters larger than $0.5 \mu \mathrm{m}$ (TSI aerodynamic particle sizer APS model 3321) and lightscattering and backscattering coefficient at dry and at relative humidity of $85 \%$ by means of a TSI tandem nephelometer humidograph system. Furthermore, the chemical composition in the $\mathrm{PM}_{1}$ and $\mathrm{PM}_{10}$ size fractions was determined during 16 and 17 June by collecting aerosol samples using two high-volume samplers (Benavent-Oltra et al., 2016).

\subsubsection{Capo Granitola station}

Several instruments were also deployed at Capo Granitola $\left(37^{\circ} 34^{\prime} \mathrm{N}, 12^{\circ} 40^{\prime} \mathrm{E}\right)$, a site along the southern coast of Sicily. The site, within a combined effort of ENEA, the University of Florence, and the University of Valencia, was equipped with a $\mathrm{PM}_{10}$ sampler, a MultiFilter Rotating Shadowband Radiometer (MFRSR) to derive spectral AOD, and radiometers and spectrometers for the measurement of global, direct, and diffuse radiation throughout the SW and LW spectral ranges.

\subsection{Surface remote-sensing network}

Two surface remote-sensing networks were operated during the ChArMEx SOP-1a experiment, namely the AERONET/PHOTONS and EARLINET/ACTRIS (Pappalardo et al., 2014) networks. These networks were highly useful as they allow estimation of the column-integrated aerosol loading as well as the vertical structure of particles. 


\subsubsection{The AERONET/PHOTONS sun-photometer network}

AERONET (Aerosol Robotic Network; http://aeronet.gsfc. nasa.gov/) is a federated network of ground-based sunphotometers and the associated data inversion and archive system that routinely performs direct sun observations about every 15 min during daytime, and both almucantar and principal plane sky radiance measurements, at selected solar angles (Holben et al., 1998). Along with AOD observations, the AERONET aerosol retrieval algorithm (Dubovik and King, 2000) delivers the complete set of column-effective aerosol microphysical parameters, including volume size distribution, refractive index at several wavelengths and fraction of spherical particles (Dubovik et al., 2006). In addition, using these microphysical parameters, the algorithm provides other column-effective aerosol optical properties such as wavelength dependent SSA, phase function, and asymmetry parameter, as well as integral parameters of bi-modal particle size distributions (concentration, mode radii and variances) (Dubovik et al., 2002). The accuracy of AERONET retrievals is evaluated and discussed by Dubovik et al. (2000, 2002). In addition to microphysical and optical aerosol properties, we also have used direct radiative forcing calculations operationally provided at any AERONET location as an operational product of the network. The method of derivation is described in detail by García et al. (2012). Briefly, the broadband fluxes were calculated using the GAME (Dubuisson et al., 2004; Roger at al., 2006) radiative transfer model that has been integrated into the operational AERONET inversion code. Sun-photometer stations used during the SOP-1a campaign over the western basin are listed in Table 2 . The new instruments deployed specifically during the ChArMEx/ADRIMED project are the Ersa, Cap d'En Font, Cagliari and Majorque stations.

\subsubsection{The EARLINET/ACTRIS network}

Between 22 and 24 June, four ACTRIS/EARLINET lidar stations (in addition to the EARLINET sites of Barcelona and Granada) were operated (Sicard et al., 2015a; Barragan et al., 2016):

- Naples: backscatter (355 and $532 \mathrm{~nm}$ ) and depolarization ratio $(532 \mathrm{~nm})$ profiles (22 June);

- Serra La Nave (Sicily): backscatter (355 nm) and depolarization ratio $(355 \mathrm{~nm})$ profiles (22 June);

- Potenza: extinction profiles ( 355 and $532 \mathrm{~nm}$ ), backscatter $(1064 \mathrm{~nm})$ and depolarization ratio $(532 \mathrm{~nm})$ profiles (22 and 23 June);

- Lecce: extinction (355 and $532 \mathrm{~nm}$ ), backscatter $(1064 \mathrm{~nm})$, water vapor and depolarization ratio $(355 \mathrm{~nm})$ profiles (22 and 24 June).
ADRIMED flights - ATR42 \& Falcon20 - June \& July 2013
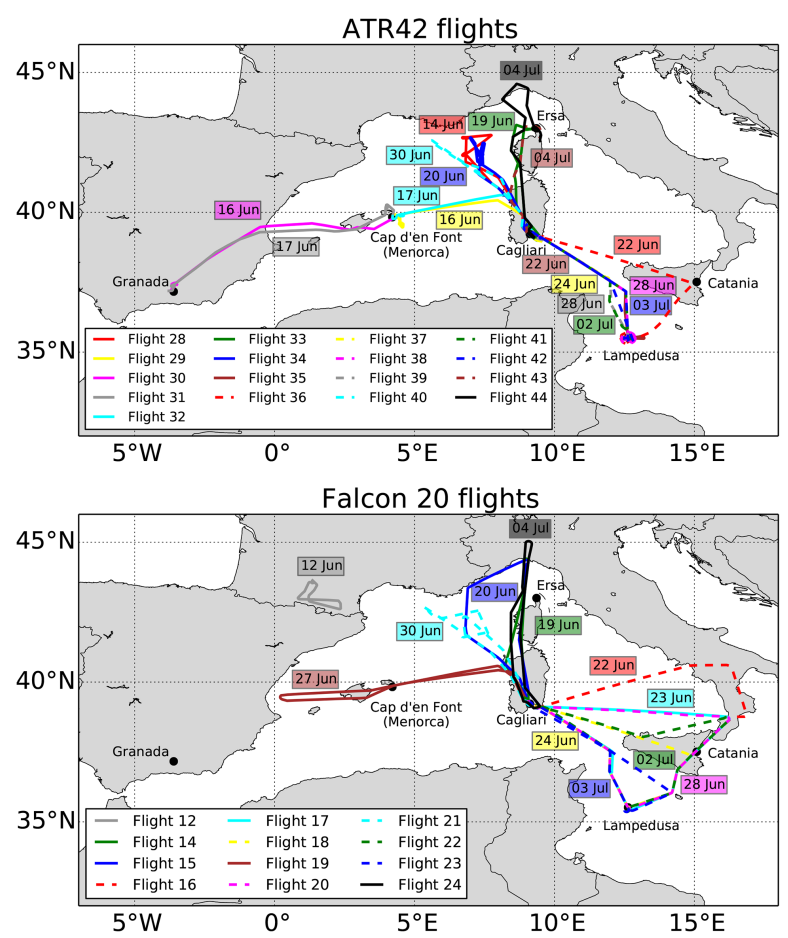

Figure 3. Overview of the different ATR-42 and F-20 flight trajectories performed during the SOP-1a experiment.

\section{Overview of the aircraft and balloon operations}

\subsection{Overview of the ATR-42 and F-20 flights}

Figure 3 summarizes ATR-42 and F-20 flights trajectories performed during the experiment and their main characteristics. Most of the western Mediterranean basin has been investigated during the campaign by both aircrafts, excluding areas under the control of African aviation authorities where authorizations for scientific operations are very difficult to obtain. The first period of the campaign (16 to 20 June) was mainly dedicated to ATR-42 flights over Spain and Minorca (16-17 June, flights 29-32) and southern France-Corsica (19-20 June, flights 33-34). During the second period (2128 June) of the SOP-1a, ATR-42 flights were mostly conducted over the Sardinia-Sicily-Lampedusa region in the central Mediterranean (flights 35-40). In July, two ATR-42 flights (41 and 42) were conducted over Lampedusa on 2 3 July and two others (43 and 44) on 4 July over the Gulf of Genoa. It should be noted that most ATR-42 flights included some transects at fixed altitudes (generally $\sim 30 \mathrm{~min}$ of duration) associated with vertical profiles over surface supersites and secondary stations. Details about each flight track are available on the ChArMEx Operation Centre website (ChOC; http://choc.sedoo.fr). In Fig. 3, F-20 flights trajectories are also indicated with the day corresponding to each 
Table 2. List of the long-term AERONET/PHOTONS sun-photometer stations operated in the western Mediterranean during the ChArMEx/ADRIMED (SOP-1a) experiment.

\begin{tabular}{lrrrrl}
\hline $\begin{array}{l}\text { AERONET/PHOTONS } \\
\text { Site name }\end{array}$ & $\begin{array}{r}\text { Latitude } \\
\left({ }^{\circ} \mathrm{N}\right)\end{array}$ & $\begin{array}{r}\text { Longitude } \\
\left({ }^{\circ} \mathrm{E}\right)\end{array}$ & $\begin{array}{r}\text { Altitude } \\
(\mathrm{m})\end{array}$ & $\begin{array}{r}\text { Nb. of } \\
\text { wavelengths }\end{array}$ & $\begin{array}{l}\text { Site } \\
\text { characteristics }\end{array}$ \\
\hline Modena & 44.63 & 10.94 & 56 & 7 & Urban \\
Avignon & 43.93 & 4.87 & 32 & 4 & Rural \\
Villefranche-sur-Mer & 43.68 & 7.33 & 130 & 4 & Peri-urban coastal \\
Frioul & 43.26 & 5.29 & 40 & 8 & Peri-urban coastal \\
Toulon & 43.13 & 6.00 & 50 & 4 & Urban coastal \\
Ersa & 43.00 & 9.35 & 80 & 8 & Remote island \\
Rome Tor Vergata & 41.84 & 12.65 & 130 & 7 & Peri-urban \\
Barcelone & 41.38 & 2.17 & 125 & 4 & Urban coastal \\
IMAA-Potenza & 40.60 & 15.72 & 820 & 8 & Urban \\
Lecce University & 40.33 & 18.11 & 30 & 7 & Peri-urban coastal \\
Cap d'en Font & 39.82 & 4.21 & 10 & 7 & Remote island \\
Oristano & 39.91 & 8.5 & 10 & 4 & Peri-urban coastal \\
Burjassot & 39.50 & -0.42 & 30 & 8 & Urban coastal \\
Majorque & 39.55 & 2.62 & 10 & 7 & Peri-urban coastal \\
Cagliari & 39.28 & 9.05 & 3 & 7 & Urban coastal \\
Messina & 38.20 & 15.57 & 15 & 4 & Urban coastal \\
Granada & 37.16 & -3.6 & 680 & 7 & Urban \\
Malaga & 36.71 & -4.47 & 40 & 7 & Peri-urban \\
Blida & 36.50 & 2.88 & 230 & 7 & Rural coastal \\
Lampedusa & 35.51 & 12.63 & 45 & 7 & Remote island \\
Ouijda & 34.65 & 1.90 & 620 & 8 & Urban coastal \\
Ouarzazate & 30.93 & 6.91 & 1136 & 8 & Remote desert \\
\hline
\end{tabular}

flight. Except for 16 and 17 June, when F-20 is not flying, most of the flights have been made jointly between the two aircraft. The longer flight range of the F-20 allowed us to document the Tyrrhenian Sea (not covered by the ATR-42) and to perform vertical profiles of aerosols over southern Italy in association with EARLINET/ACTRIS lidar observations. It should be finally noted the additional F-20 flight between Sardinia and Spain on 27 June specifically dedicated to sample a forest fire plume transported long-range from North America.

\subsection{In situ and remote-sensing observations onboard the ATR-42}

The instrumentation deployed onboard the ATR-42, described in detail in Denjean et al. (2015) and Nicolas et al. (2016) is summarized in Table 3. It is analogous to the one used for the two super-sites and was devoted to the characterization of microphysical, chemical and optical properties of aerosols that have been advected above the MBL and so not detectable at the surface. As indicated in Table 3, the number size distribution of aerosols, including fine and coarse fractions, as well as the total concentration of particles have been evaluated using SMPS, GRIMM, FSSP and UHSAS systems. The corresponding size ranges for all instruments are indicated in Table 3. A 3- $\lambda$ nephelometer and $1-\lambda$ Cavity Attenuated Phase Shift (CAPS PMex) particle light extinc- tion monitor system (Petzold et al., 2013) have been used conjointly for estimating scattering and extinction properties of particles. The CAPS-PMex system, used for the first time onboard the ATR-42, provides an additional constrain on the aerosol optical properties, useful to determine the absorbing properties. Indeed, the aerosol absorbing characterization remains largely challenging using filter techniques (Moosmüller et al., 2009). These optical inter-comparisons have been performed for different aerosol plumes and are presented in Denjean et al. (2015).

In addition, passive remote-sensing observations have been conducted during the SOP-1a experiment using the PLASMA (Photomètre Léger Aéroporté pour la Surveillance des Masses d'Air) system, which is an airborne suntracking photometer with two main characteristics: lightness and a wide spectral coverage (15 channels between 0.34 and $2.25 \mu \mathrm{m}$; see Karol et al., 2013). The instrument also contains a microprocessor that derives the sun's position depending on time, latitude, longitude (provided by a GPS system) and the rotation of the airborne (provided by a gyroscope). Spectral AOD is derived from these direct sun measurements and the calibration coefficients. During the campaign, several AOD comparisons were done between PLASMA and AERONET/PHOTONS sun-photometers (Cagliari, Lampedusa, Granada) showing differences within 0.01 at all wavelengths. Moreover, as a consequence of performing AOD measurements at different heights, the aerosol extinction 
Table 3. In situ instrumentation deployed onboard the ATR-42 during the SOP-1a experiment.

\begin{tabular}{|c|c|c|c|c|c|}
\hline Parameter measured & Instrument & Abbreviation & $\begin{array}{l}\text { Location in the } \\
\text { aircraft }\end{array}$ & $\begin{array}{l}\text { Wavelength } \\
\qquad(\mathrm{nm})\end{array}$ & $\begin{array}{c}\text { Nominal size } \\
\text { range }(\mu \mathrm{m})\end{array}$ \\
\hline \multirow[t]{5}{*}{ Size distribution } & $\begin{array}{l}\text { Forward Scattering Spectrometer } \\
\text { Probe, } \\
\text { Model 300, Particle Measuring Sys- } \\
\text { tems }\end{array}$ & FSSP-300 & Wing-mounted & 632.8 & $0.28-20$ \\
\hline & $\begin{array}{l}\text { Ultra High Sensitivity Aerosol Spec- } \\
\text { trometer, } \\
\text { Droplet Measument Technologies }\end{array}$ & UHSAS & Wing-mounted & 1054 & $0.04-1$ \\
\hline & $\begin{array}{l}\text { Sky-Optical Particle Counter, } \\
\text { Model 1.129, Grimm Technik }\end{array}$ & GRIMM1 & AVIRAD inlet & 655 & $0.25-32$ \\
\hline & $\begin{array}{l}\text { Optical Particle Counter, } \\
\text { Model 1.109, Grimm Technik }\end{array}$ & GRIMM2 & $\begin{array}{l}\text { Communautary } \\
\text { aerosol inlet }\end{array}$ & 655 & $0.25-32$ \\
\hline & $\begin{array}{l}\text { Scanning mobility particle sizer, } \\
\text { custom-built (Villani et al., 2007) }\end{array}$ & SMPS & $\begin{array}{l}\text { Communautary } \\
\text { aerosol inlet }\end{array}$ & $\mathrm{n} / \mathrm{a}$ & $0.03-0.4$ \\
\hline $\begin{array}{l}\text { Integrated number } \\
\text { concentration }\end{array}$ & $\begin{array}{l}\text { Condensation Particle Counters, } \\
\text { Model 3075, TSI }\end{array}$ & $\mathrm{CPC}$ & AVIRAD inlet & $\mathrm{n} / \mathrm{a}$ & $>0.005$ \\
\hline Scattering coefficient & $\begin{array}{l}3 \lambda \text { Integrated Nephelometer, } \\
\text { Model 3563, TSI }\end{array}$ & Nephelometer & AVIRAD inlet & $450,550,700$ & $\mathrm{n} / \mathrm{a}$ \\
\hline \multirow[t]{2}{*}{ Absorption coefficient } & $\begin{array}{l}3 \lambda \text { Particle Soot Absorption Photome- } \\
\text { ter, }\end{array}$ & PSAP & Communautray & $467,530,660$ & $\mathrm{n} / \mathrm{a}$ \\
\hline & Radiance Research & & aerosol inlet & & \\
\hline \multirow[t]{2}{*}{ Extinction coefficient } & $\begin{array}{l}\text { Cavity Attenuated Phase Shift, } \\
\text { Aerodyne Research Inc. }\end{array}$ & CAPS & $\begin{array}{l}\text { Communautary } \\
\text { Aerosol inlet }\end{array}$ & 530 & $\mathrm{n} / \mathrm{a}$ \\
\hline & $\begin{array}{l}\text { Photomètre Léger Aéroporté pour la } \\
\text { Surveillance des Masses d'Air }\end{array}$ & PLASMA & roof-mounted & $340-2250$ & $\mathrm{n} / \mathrm{a}$ \\
\hline \multirow[t]{2}{*}{ Chemical composition } & Filter sampling & $\mathrm{n} / \mathrm{a}$ & AVIRAD inlet & $\mathrm{n} / \mathrm{a}$ & $\mathrm{n} / \mathrm{a}$ \\
\hline & $\begin{array}{l}\text { Single particle soot photometer, } \\
\text { Droplet Measurement Technologies }\end{array}$ & SP2 & $\begin{array}{l}\text { Communautary } \\
\text { Aerosol inlet }\end{array}$ & 1064 & $0.08-0.5$ \\
\hline
\end{tabular}

vertical profiles have also been obtained during every landing/taking off and during pre-scheduled vertical profiles (Torres et al., 2016). Finally, upward and downward radiative fluxes (SW and LW) have been measured onboard the ATR42 by means of CMP22 and CGR4 radiometers calibrated before the campaign.

\subsection{Remote-sensing observations onboard the F-20}

\subsubsection{LNG observations}

The LEANDRE Nouvelle Generation (LNG) was used in its backscatter configuration during the ChArMEx-ADRIMED field operation onboard the SAFIRE F-20 aircraft. In the present campaign, the LNG system involved three elastic channels at 1064, 532 and $355 \mathrm{~nm}$. Depolarization was also measured in a fourth channel operating at $355 \mathrm{~nm}$. The profiles of atmospheric particulate extinction and backscatter coefficients are then retrieved. Zenith pointing lidar measurements were taken before most of the flights from the ground at the Cagliari airport $\left(39.25^{\circ} \mathrm{N}, 9.06^{\circ} \mathrm{E}\right)$ in Italy.
Lidar observations allow the detection of biomass burning plumes (BBP) (see Sect. 4.3) arriving at the Cagliari airport on 28 June as described by Ancellet et al. (2015).

\subsubsection{OSIRIS observations}

OSIRIS (Observing System Including PolaRisation in the Solar Infrared Spectrum) is an instrument devoted to observation of the polarization and directionality of the solar radiation reflected by the surface-atmosphere system. OSIRIS is based on the same imaging radiometer concept as the POLDER instrument (Deschamps et al., 1994). It includes two optical systems: one for the visible and near infrared range (VIS-NIR, from 440 to $940 \mathrm{~nm}$ ) and the other for the shortwave infrared (SWIR, from 940 to $2200 \mathrm{~nm}$ ). OSIRIS has eight spectral bands in the VIS-NIR and six in the SWIR. During the SOP-1a campaign, OSIRIS was flown aboard the French F-20 aircraft and looked at nadir. The quantities used to derive the aerosol and cloud properties from OSIRIS are the normalized total and polarized (unitless) radiances. The aerosol algorithm used for OSIRIS over ocean is an optimal 


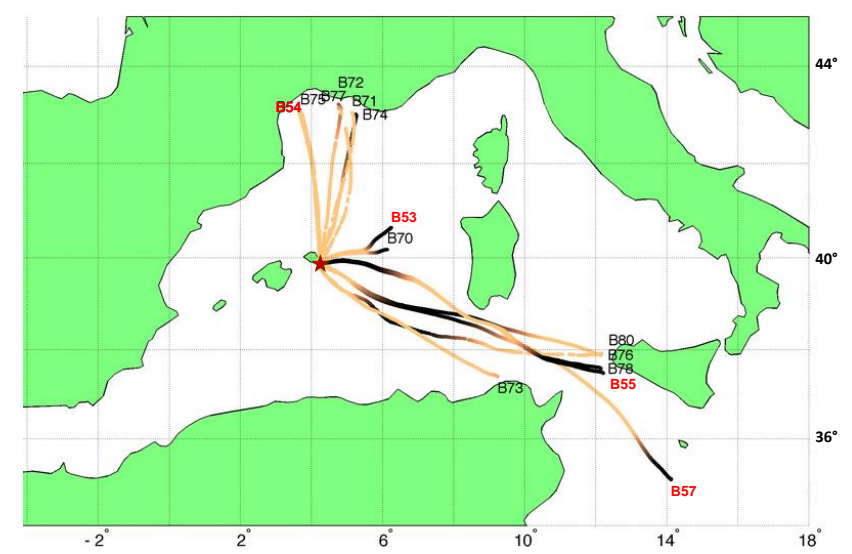

Figure 4. Trajectories of the 14 BPCL drifting balloons launched from Minorca during the campaign. Dark portions along trajectories correspond to night-time conditions. The four red labels from B54 to B57 indicate balloons with an ozone sonde and the 10 others carried a LOAC instrument.

estimation method (OEM), similar to the one described in Waquet et al. (2013). For ocean targets, we use all the available angular and polarized information acquired in three spectral bands $(490,670$ and $865 \mathrm{~nm})$ to derive the aerosol parameters and some properties of the surface. A combination of two log-normal size distribution functions is assumed (i.e., a fine mode and a coarse mode) as well as a mixture of spherical and non-spherical particles (Dubovik et al., 2006). The main retrieved parameters are the aerosol AOD, SSA, the fraction of spherical particles within the coarse mode and the complex refractive index.

\subsection{Balloon operations}

Instrumented balloons were launched by the French Space Agency (CNES) from the airfield of Sant Lluís ( $39^{\circ} 51^{\prime} 55^{\prime \prime} \mathrm{N}$, $4^{\circ} 15^{\prime} 15^{\prime \prime}, 55 \mathrm{~m}$ a.s.l.) on Minorca, less than $6 \mathrm{~km} \mathrm{NE}$ of the Cap d'en Font station described above. Two types of balloons were launched to document dust transport events: (i) ascending dilatable rubber balloons, and (ii) quasi-Lagrangian spherical pressurized drifting balloons, called BPCL (Ballon Pressurisé de Couche Limite, or boundary-layer pressurized balloons).

A total of 15 sounding balloons were launched during the campaign between 12 June and 2 July (Table 4) and most balloons reached more than $30 \mathrm{~km}$ in altitude. Except for the first test balloon on 12 June, the payload of sounding balloons included a pair of meteorological sondes with temperature, humidity and GPS sensors allowing the retrieval of the position $( \pm 10 \mathrm{~m})$, derived pressure $( \pm 1 \mathrm{hPa})$ and wind $\left( \pm 0.15 \mathrm{~m} \mathrm{~s}^{-1}\right)$, respectively coupled, for certain flights (see Tables 4 and 5), to an ozone electrochemical sonde (Gheusi et al., 2015) and a LOAC OPC (Renard et al., 2015a, b). Balloon trajectories were confined within the area $39-41.2^{\circ} \mathrm{N}$ in latitude and 3$5^{\circ} \mathrm{E}$ in longitude.
BPCLs are designed to drift and make observations with a payload of a few $\mathrm{kg}$ in the lower troposphere for durations of up to several weeks (Vialard et al., 2009). Two versions were used, the standard one of $2.5 \mathrm{~m}$ in diameter, launched pressurized, which is limited to a maximum float altitude of about $2.5 \mathrm{~km}$ (Ducrocq et al., 2014), and one developed for ChArMEx of $2.6 \mathrm{~m}$ in diameter, launched unpressurized to reach a float altitude of more than $3 \mathrm{~km}$ in altitude. The payload was composed of a GPS system, PTU instruments on the upper pole of the balloon, a LOAC instrument on the lower pole of the balloon and two solar radiation sensors for upward and downward solar flux measurements. In addition a BPCL equipped with a modified ozone electrochemical sonde (Gheusi et al., 2015) instead of a LOAC was launched in parallel of a LOAC balloon on 4 occasions on 16 and 17 June (BPCL B53 and B54, respectively), and on 2 July (BPCL B55 and B57). 14 BPCL balloons were launched in total between 16 June and 2 July 2013 (Table 5). Trajectories are plotted in Fig. 4 with a visualization of daytime vs. night-time conditions. The longest flight in terms of distance $(1053 \mathrm{~km})$ and time duration $(32.6 \mathrm{~h})$ was the ozone BPCL B57, which passed the Sicily Strait and reached the southern limit of the authorized flight domain south-southwest of Malta. Communication failure occurred with the two balloons B53 and B70. Flights were automatically terminated by drilling the envelope at a distance of $30 \mathrm{~km}$ from the southeastern French coasts, the western Sicilian coast, or the northern Tunisian coast. BPCL float altitudes ranged between about 1850 and 3350 m a.m.s.l. (balloon B54 with an ozone sonde and B71 with a LOAC, respectively). Pairs of balloons with LOAC measurements were launched at different float altitudes to document Saharan dust transport on 16 June $(2100$ and $\sim 3100$ ma.m.s.l.) and 19 June (2550 and $\sim 3500$ m a.m.s.l.).

\section{Overview of meteorological conditions}

\subsection{Synoptic situation}

As mentioned below, the SOP-1a experiment was mostly characterized by moderate aerosol loading mainly controlled by the contribution of mineral dust particles. This situation is well observed through the AOD derived by MODIS (Tanré et al., 1997), MISR (Kahn et al., 2010), PARASOL (Tanré et al., 2011) or SEVERI (Thieuleux et al., 2005) sensors and averaged for the June-July 2013 period (Fig. 5), which show an average AOD ranging between 0.2 and 0.4 (at $550 \mathrm{~nm}$ ) over the western and central Mediterranean basins. During the SOP-1a, distinct meteorological conditions have led to the transport of mineral dust over the basin as shown in Figs. 5 and 6. Figure 7 shows the dust mass concentration together with the geopotential and wind at $700 \mathrm{hPa}$ for 16 , 19, 22, 29 June and 2 July. In the following sections, we discuss the meteorological conditions (surface wind, sea level 
Table 4. Characteristics of the 15 sounding balloon flights from Sant Lluis, Minorca, during the ChArMEx SOP1a/ADRIMED campaign.

\begin{tabular}{|c|c|c|c|c|c|c|}
\hline No. & Date (2013) & Start time (UTC) & Ceiling altitude (m) & Latitude at ceiling & Longitude at ceiling & Sensors \\
\hline BLD1 & 12 June & $21: 13$ & 21178 & $39.5156^{\circ} \mathrm{N}$ & $04.3010^{\circ} \mathrm{E}$ & $T, U$ \\
\hline BLD2 & 15 June & $21: 40$ & 32119 & $39.9903^{\circ} \mathrm{N}$ & $04.1801^{\circ} \mathrm{E}$ & $T, U, \mathrm{LOAC}, \mathrm{O}_{3}$ \\
\hline BLD3 & 16 June & $10: 29$ & 31880 & $40.0527^{\circ} \mathrm{N}$ & $04.1524^{\circ} \mathrm{E}$ & $T, U, \mathrm{LOAC}, \mathrm{O}_{3}$ \\
\hline BLD4 & 16 June & $21: 13$ & 33390 & $40.0999^{\circ} \mathrm{N}$ & $04.0118^{\circ} \mathrm{E}$ & $T, U, \mathrm{LOAC}, \mathrm{O}_{3}$ \\
\hline BLD5 & 17 June & $10: 01$ & 32744 & $40.2109^{\circ} \mathrm{N}$ & $03.9672^{\circ} \mathrm{E}$ & $T, U, \mathrm{LOAC}, \mathrm{O}_{3}$ \\
\hline BLD6 & 17 June & $18: 25$ & 33411 & $40.2502^{\circ} \mathrm{N}$ & $03.9402^{\circ} \mathrm{E}$ & $T, U, \mathrm{LOAC}, \mathrm{O}_{3}$ \\
\hline BLD7 & 18 June & $16: 34$ & 35635 & $40.5832^{\circ} \mathrm{N}$ & $04.0515^{\circ} \mathrm{E}$ & $T, U, \mathrm{LOAC}$ \\
\hline BLD8 & 18 June & $21: 17$ & 21507 & $40.6372^{\circ} \mathrm{N}$ & $04.4889^{\circ} \mathrm{E}$ & $T, U, \mathrm{LOAC}, \mathrm{O}_{3}$ \\
\hline BLD9 & 19 June & $10: 12$ & 30902 & $40.6794^{\circ} \mathrm{N}$ & $04.3691^{\circ} \mathrm{E}$ & $T, U, \mathrm{LOAC}, \mathrm{O}_{3}$ \\
\hline BLD10 & 19 June & $13: 48$ & 36129 & $40.6553^{\circ} \mathrm{N}$ & $04.1970^{\circ} \mathrm{E}$ & $T, U, \mathrm{LOAC}$ \\
\hline BLD11 & 27 June & $09: 43$ & 35832 & $39.7546^{\circ} \mathrm{N}$ & $04.4746^{\circ} \mathrm{E}$ & $T, U, \mathrm{LOAC}$ \\
\hline BLD12 & 28 June & $05: 36$ & 36293 & $39.4505^{\circ} \mathrm{N}$ & $04.1709^{\circ} \mathrm{E}$ & $T, U, \mathrm{LOAC}$ \\
\hline BLD13 & 29/30 June & $23: 31$ & 36310 & $39.6168^{\circ} \mathrm{N}$ & $03.7383^{\circ} \mathrm{E}$ & $T, U, \mathrm{LOAC}$ \\
\hline BLD14 & 30 June & $14: 03$ & 36319 & $39.8937^{\circ} \mathrm{N}$ & $03.9568^{\circ} \mathrm{E}$ & $T, U, \mathrm{LOAC}$ \\
\hline BLD15 & 2 July & $10: 27$ & 32833 & $39.9942^{\circ} \mathrm{N}$ & $04.2996^{\circ} \mathrm{E}$ & $T, U, \mathrm{LOAC}, \mathrm{O}_{3}$ \\
\hline
\end{tabular}

Table 5. Characteristics of the 14 BPCL drifting balloon flights.

\begin{tabular}{|c|c|c|c|c|c|c|}
\hline $\begin{array}{l}\text { Date and time of } \\
\text { launch (UT) }\end{array}$ & $\begin{array}{l}\text { Balloon Nbr and } \\
\text { type of sensor }\end{array}$ & $\begin{array}{l}\text { Last data time } \\
\text { (UT) }\end{array}$ & Last data location & $\begin{array}{c}\text { Trajectory length } \\
(\mathrm{km})\end{array}$ & $\begin{array}{l}\text { Flight duration } \\
\text { (h) }\end{array}$ & $\begin{array}{l}\text { Approximate float } \\
\text { altitude }(\mathrm{m})\end{array}$ \\
\hline 16 June, 09:46 & B74, LOAC & 16 June, $21: 51$ & $43.0265^{\circ} \mathrm{N}, 05.2285^{\circ} \mathrm{E}$ & 368 & $11: 57$ & 2100 \\
\hline 16 June, 09:58 & B70, LOAC & 16 June, 23:01 & $40.1825^{\circ} \mathrm{N}, 06.1293^{\circ} \mathrm{E}$ & 174 & $13: 17$ & $3050-3150$ \\
\hline 17 June, 09:27 & $\mathrm{B} 54, \mathrm{O} 3$ & 17 June, $16: 49$ & $43.1433^{\circ} \mathrm{N}, 03.5293^{\circ} \mathrm{E}$ & 371 & $07: 22$ & $1850-2000$ \\
\hline 17 June, 09:29 & B75, LOAC & 17 June, 16:51 & $43.0868^{\circ} \mathrm{N}, 03.6866^{\circ} \mathrm{E}$ & 365 & $07: 23$ & $1950-2050$ \\
\hline 19 June, 10:35 & B71, LOAC & 19 June, 15:03 & $43.0560^{\circ} \mathrm{N}, 05.1336^{\circ} \mathrm{E}$ & 369 & $04: 39$ & $3250-3350$ \\
\hline 27 June, 10:00 & B80, LOAC & 28 June, 12:07 & $37.9165^{\circ} \mathrm{N}, 12.1605^{\circ} \mathrm{E}$ & 759 & $26: 19$ & $2950-3050$ \\
\hline 28 June, 05:20 & B73, LOAC & 28 June, $17: 24$ & $37.4095^{\circ} \mathrm{N}, 09.2346^{\circ} \mathrm{E}$ & 523 & $12: 16$ & $2650-2750$ \\
\hline 2 July, 13:03 & B76, LOAC & 03 July, 09:38 & $37.8897^{\circ} \mathrm{N}, 12.1312^{\circ} \mathrm{E}$ & 731 & $20: 39$ & $3150-3250$ \\
\hline 2 July, 13:11 & $\mathrm{B} 57, \mathrm{O} 3$ & 03 July, 22:43 & $35.0900^{\circ} \mathrm{N}, 14.1140^{\circ} \mathrm{E}$ & 1053 & $33: 44$ & $3100-3200$ \\
\hline 2 July, 17:59 & B55, O3 & 04 July, 02:20 & $37.3545^{\circ} \mathrm{N}, 12.21980 \mathrm{E}$ & 762 & 32.32 & $2400-2450$ \\
\hline
\end{tabular}

pressure, $700 \mathrm{hPa}$ geopotential and wind direction) for these different days in order to understand the transport of mineral dust aerosols over the Mediterranean.

Wind direction and intensity vertical profiles as simulated by the ALADIN-Dust (Mokhtari et al., 2012) model (outputs every $3 \mathrm{~h}$ ) as a function of time, for the 11 June to 6 July period and for the whole SOP-1a period at three different sites, Ersa, Minorca and Lampedusa, are shown in Fig. 8. At the beginning of the SOP-1a, the northwestern Mediterranean area was under the influence of a large pressure ridge at $700 \mathrm{hPa}$, generating a westerly to southwesterly flow over Spain and southern France. Over Minorca, the near-surface $(1000-850 \mathrm{hPa})$ winds were generally from the easterly to northeasterly directions (indicated by the blue color in Fig. 8), while the wind direction estimated between 700 and $500 \mathrm{hPa}$ was clearly from the south-southwesterly direction (brown color), which is a favorable condition for the transport of mineral dust above southern Spain and the Balearic Islands (Fig. 6). This point is well observed in Fig. 7, showing the geopotential at $700 \mathrm{hPa}$ for 16 June. The general circulation at $700 \mathrm{hPa}$ during this dust event indicates a reinforcement of the southwesterly winds in southern Spain advecting air masses with large concentrations of dust aerosols as shown by SEVIRI AOD (AOD of 0.4-0.5) for that day (Fig. 6). A low-pressure system moved from the British Isles towards the Gulf of Biscay and then the Iberian Peninsula between 17 and 20 June, leading to veering winds that became southerly over the northwestern Mediterranean. Thus, in Minorca, the direction of the wind changed from an easterly to a southerly direction between 1000 and $850 \mathrm{hPa}$. A more pronounced southerly-southwesterly flow was also observed at $700 \mathrm{hPa}$ in Minorca (19-21 June) as shown by the geopotential at $700 \mathrm{hPa}$. This circulation characterized by the presence of the low geopotential over the Gulf of 


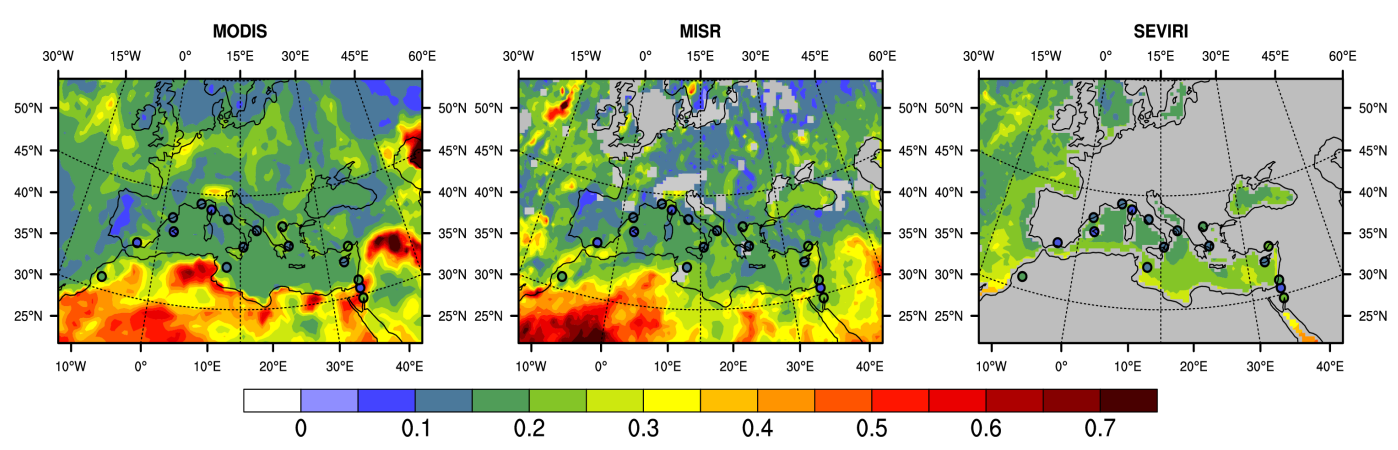

Figure 5. Total AOD $(550 \mathrm{~nm})$ obtained from the MODIS, MISR and SEVIRI (sea only) sensors for the June-July 2013 period. The AERONET/PHOTONS AOD is also indicated.

Biscay induced a strong southerly flow at $700 \mathrm{hPa}$ between the Balearic Islands and Corsica associated with large dust optical depth concentrated in this zone as shown by SEVIRI AOD (AOD of 0.3-0.4) for 19 June (Fig. 6). This period of the SOP-1a corresponds to the two ATR-42 flights 33 and 34 (Fig. 3). After 20 June, this low-pressure system moved eastward, generating a trough located between France and Italy, and inducing a waving westerly flow over the northwestern Mediterranean. As a result, the aerosol loading over the western basin decreased between 21 and 24 June, but the westerly (northerly) winds observed at $700 \mathrm{hPa}$ in Minorca (Ersa) (Fig. 8) reinforced the transport of dust aerosols over the central basin and the Lampedusa station (where winds were from the northwesterly direction at $3 \mathrm{~km}$ height). These meteorological conditions lead to an increase of the dust optical depth over the central Mediterranean as shown by the SEVERI instrument and AERONET/PHOTONS data. Between 25 and 29 June, a northwesterly flow set up between the Gulf of Lion and Sicily. The vertical profiles of the wind direction reveal a remarkable transition on 29 June with significant changes in direction from westerlies to north-northwesterlies, notably over the Minorca and Ersa stations above $850 \mathrm{hPa}$. The $700 \mathrm{hPa}$ geopotential field on 29 June at 12:00 UTC from the ERA-Interim reanalysis (Fig. 7) shows a maximum over the Atlantic Ocean, whereas a deep low-pressure system was located over southern Algeria. This strong geopotential gradient leads to intense northerly to northwesterly winds at $700 \mathrm{hPa}$ over the western basin, leading to significant AOD over Libya (AOD of 0.4-0.5) and the Alboran Sea (AOD of 0.5-0.6) as shown in Fig. 6. These meteorological conditions lead to low dust optical thickness over the central Mediterranean as observed by AERONET/PHOTONS data. Finally, during the last period of the SOP-1a experiment (30 June5 July), weather conditions became more anticyclonic over the region, while low systems were confined to northern Europe. Figure 8 shows northwesterly winds in the whole troposphere in Lampedusa and Minorca, limiting the presence of dust aerosols to the southern part of the northwestern Mediterranean.

\subsection{Surface temperature, cloud cover and precipitation}

In terms of surface temperature, which is one of the most important meteorological variables that control biogenic or biomass burning aerosol emissions over the EuroMediterranean region, the summer 2013 was mostly characterized by moderate values as shown in Fig. 9. Indeed, during the SOP-1a period, surface temperatures (in ${ }^{\circ} \mathrm{C}$ and at 12:00 UTC) derived from NCEP reanalysis (Kalnay et al., 1996) for different days reveal moderate values, especially over the western Mediterranean region (southwestern France and Spain). One can observe temperatures of about $15-20^{\circ} \mathrm{C}$ (at 12:00 UTC) over Spain and Portugal, which are one of the main regions of the Mediterranean where large fire events occur. In addition, part of France was also characterized by moderate surface temperature but slightly higher than over Spain especially over northeastern regions. A strong west to east gradient is observed over Europe with strongest values over the eastern regions (around $30^{\circ} \mathrm{C}$ over Greece and the Balkans) compared to the western basin. A similar conclusion is obtained over the Mediterranean Sea with differences of about $5{ }^{\circ} \mathrm{C}$ between the eastern (around $25^{\circ} \mathrm{C}$ for the SOP-1a period) and the western (around $20^{\circ} \mathrm{C}$ ) basins. Among other factors (such as cloud fraction and shortwave radiations), such moderate surface temperatures do not create favorable meteorological conditions to produce intense Mediterranean biomass burning events and/or significant production of secondary organic and inorganic aerosols. Concerning smoke aerosols, GAFS-V1 emission data, analyzed for the SOP-1a period, do not reveal important primary BC and OC flux emissions (not shown). This is consistent with the APIFLAME biomass burning emission estimates (Turquety et al., 2014) data as reported by Menut et al. (2015).

During the SOP-1a, the cloud cover retrieved over the Euro-Mediterranean region (excluding the Mediterranean Sea) from CRU (Climate Research Unit) data (Harris et al., 2013) (Fig. 10) indicates the largest values (between 75 and $95 \%$ ) over the French, Benelux and eastern Europe regions. In parallel, southern France, as well as western Spain and the 

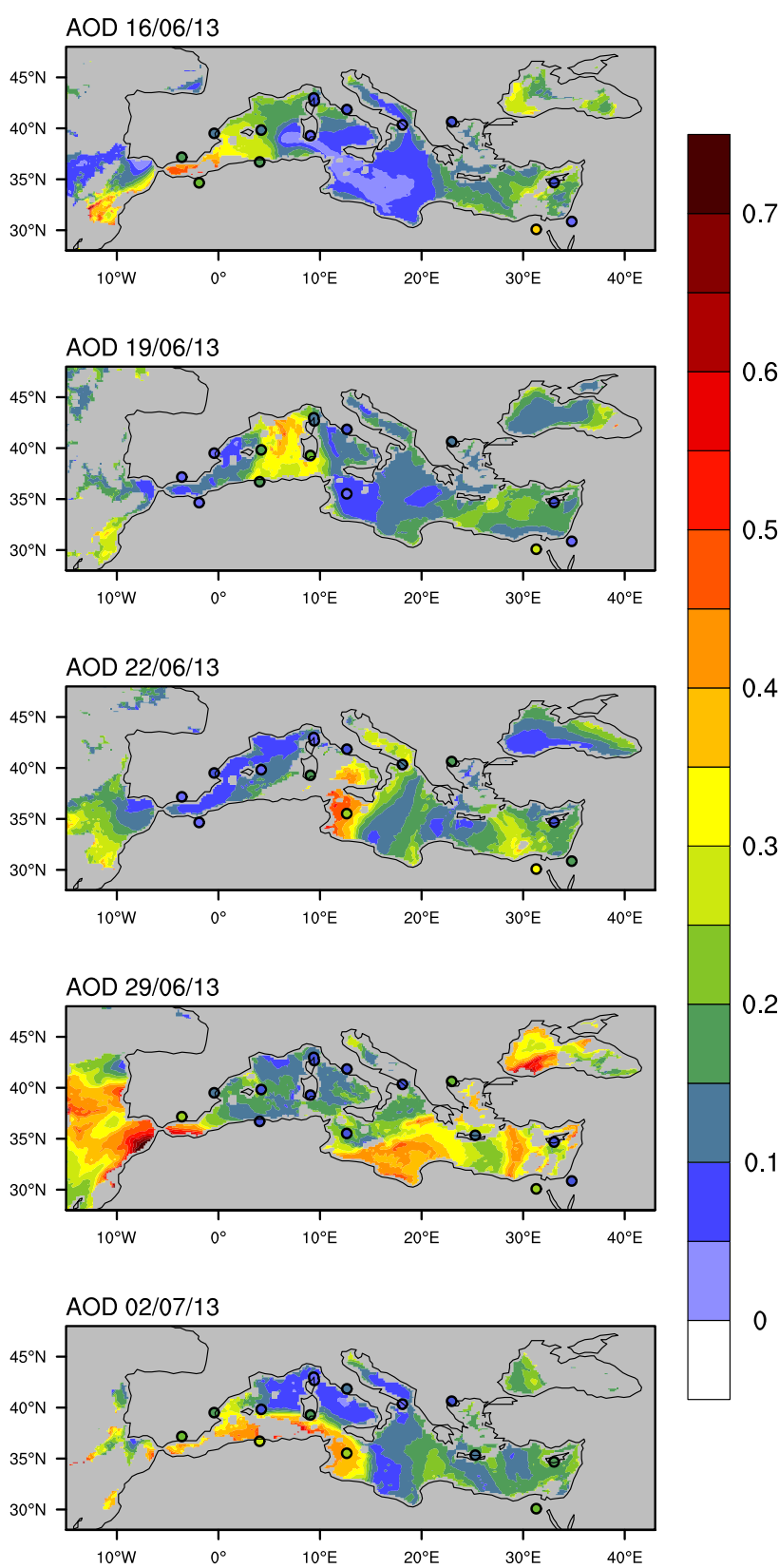

Figure 6. AOD MSG/SEVIRI observations for 5 different days during the SOP-1a experiment (16, 19, 22, and 29 June and 3 July). The AERONET/PHOTONS AOD is also indicated.

Balkans are characterized by moderate cloud cover with values around 50-60\% for June 2013. Over the Mediterranean coast, the cloud cover strongly decreases for most of countries, with values lower than $40 \%$. Such spatial cloud cover (observed during the SOP-1a) over the Euro-Mediterranean could limit the photochemical processes over the main anthropogenic sources (such as the Benelux and Po Valley) and the associated production of secondary aerosols. This could explain for a part the low to moderate contribution of fine anthropogenic particles to the total atmospheric load- ing during the SOP-1a. In parallel, the mean precipitation (averaged for June 2013), obtained from the TRMM (Tropical Rainfall Measuring Mission) instrument over land and sea (CRU observations are only available over land; see Fig. 10), are found to be very heterogeneous over the EuroMediterranean continental region, with some important values over the Balkans, Alps and eastern Europe (from 100 to $250 \mathrm{~mm}$ for the month of June 2013) and moderate values over Italy, Croatia, western France and Benelux (80 to $100 \mathrm{~mm}$, as shown in Fig. 11). Over the Mediterranean Sea, southern Spain and northern Africa, the precipitation was smaller, with most of the values lower than $20 \mathrm{~mm}$ during the SOP-1a.

To summarize, this global view of the synoptic situation, cloud cover and regional precipitation patterns indicates that the meteorological conditions during the experimental campaign were favorable to moderate mineral dust emissions, associated with a weak contribution of anthropogenic aerosols over the western basin. This important characteristic of the SOP-1a is well observed in Fig. 12, which indicates the AOD anomalies (calculated for the period 2000-2013) of summer 2013 compared to all AOD summer derived from MODIS and MISR data. Indeed, negative AOD anomalies of about -0.05 are found over the western Mediterranean basin for the summer of 2013, both from MODIS and MISR observations. To conclude, it appears that the period of observations during the SOP-1a was characterized by aerosol concentration slightly lower but in the same range of magnitude that usually observed during summer over the western Mediterranean. The level of aerosol concentration was found to be moderate but allows investigating several dust and seaspray events as well as an interesting intense biomass burning plume advected from North America.

\subsection{An aged smoke plume advected over Europe}

During the SOP-1a, several large forest fires occurred in North America (Colorado, Alaska, Canada) from 17 to 24 June 2013, as identified by the MODIS instrument. The absorbing aerosol index produced from GOME-2 by KNMI (http://www.temis.nl/aviation/aai-pmd-gome2b.php? year=2013) shows that a large smoke plume crossed the North Atlantic and reached western European coasts on 25 June. Main fire areas, with fire radiative power higher than 50 MW (Shroeder et al., 2010), have been detected over Canada (Ancellet et al., 2015). Average MODIS AOD during the same period (23 to 28 June 2013) indicate values as high as 1 over the Atlantic Ocean, suggesting that a significant fraction of the aerosol produced by the fires was transported to western Europe during the ChArMEx/ADRIMED field campaign. To investigate whether the western Mediterranean has been impacted by these fires, a forward simulation of the FLEXPART (Ancellet et al., 2015) Lagrangian plume dispersion model has been conducted to quantify the spatial extent of the fire plume transport for 11 days. Fire emissions 

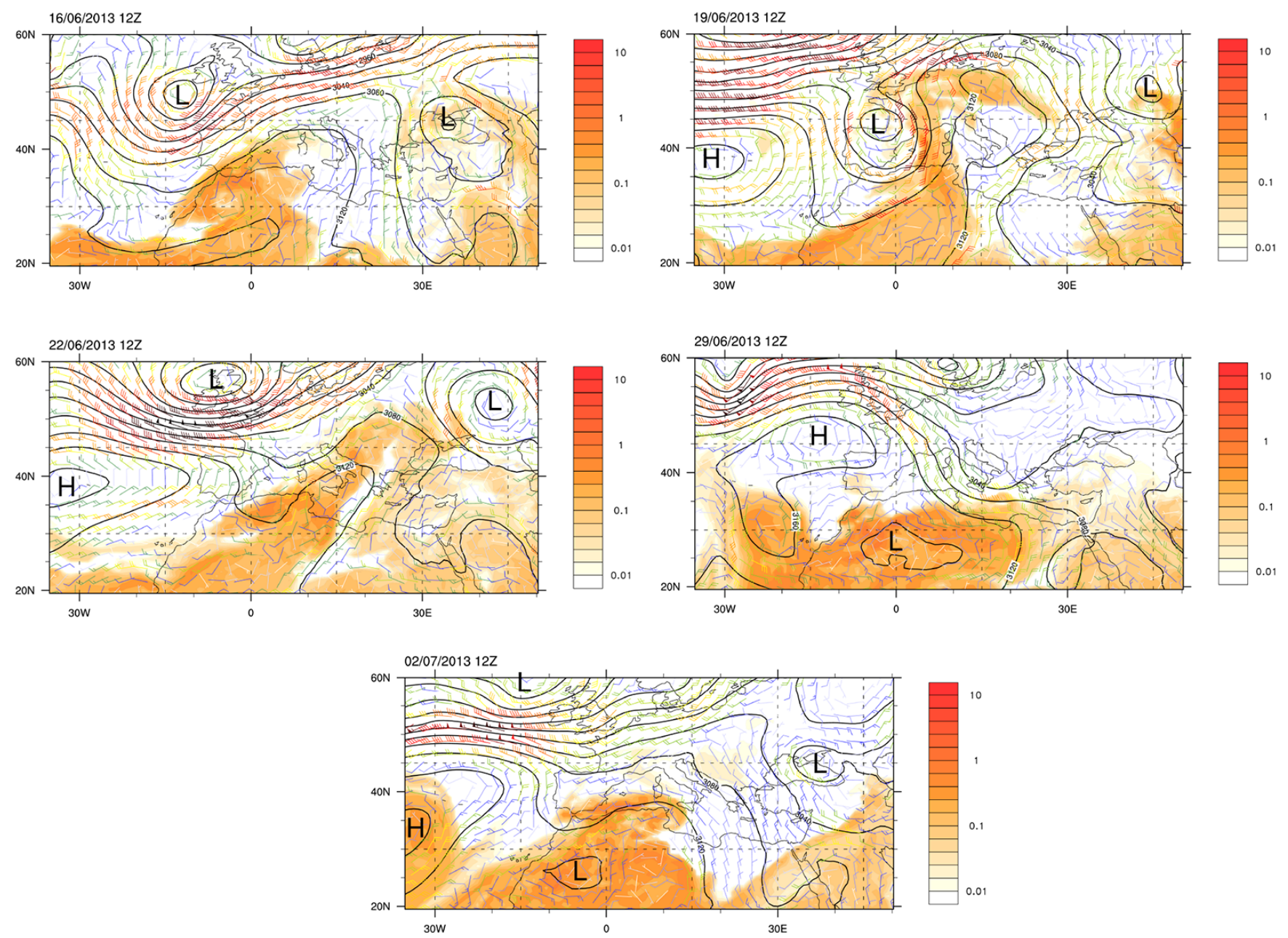

Figure 7. Geopotential and wind intensity at $700 \mathrm{hPa}$ (ERA-Interim reanalysis), and mass dust concentration (in $\mathrm{mg} \mathrm{m}^{-3}$ ) simulated from the ALADIN-Dust model for 6, 19, 22, 29 June and 2 July at 12:00 UTC.

areas were identified by MODIS observations over several locations in Canada and Colorado. The aerosol mass is emitted in the transport model from 17 to 28 June in a $3 \mathrm{~km}$ layer as suggested by the CALIOP lidar observations over Canada. The biomass burning plume reaches much lower latitudes over Europe, down to the western Mediterranean 4-10 days after the emission in Canada. During the SOP-1a, the plume was mainly present in the altitude range of $2.5-4.5 \mathrm{~km}$ and has been sampled by many remote-sensing and in situ instruments on 27 and 28 June: at the Minorca and Cagliari surface stations, and between Sardinia and Lampedusa onboard the ATR-42 aircraft.

\section{Overview of aerosol physical-chemical-optical properties, vertical profiles and local direct radiative forcing}

\subsection{Aerosol physical and chemical properties}

\subsubsection{Aerosol mass and number concentration at the two super-sites}

First, PM concentrations between the two different stations are reported in Fig. 13, which reports the daily time series of $\mathrm{PM}_{1}$ and $\mathrm{PM}_{10}$ at Ersa, as well as $\mathrm{PM}_{10}$ and $\mathrm{PM}_{40}$ at Lampedusa. The results indicate a significantly higher mass concentration at Lampedusa compared to Ersa. Indeed, the mass concentration observed at Lampedusa is comprised between 10 and $30 \mu \mathrm{g} \mathrm{m}^{-3}$, with a mean of $21 \mu \mathrm{g} \mathrm{m}^{-3}$, which is two times higher than the averaged $\mathrm{PM}_{10}\left(\sim 9 \mu \mathrm{g} \mathrm{\textrm {m } ^ { - 3 }}\right)$ measured at Ersa. One can note the significant peak of $\mathrm{PM}_{40}$ (maxima of $75 \mu \mathrm{g} \mathrm{m}^{-3}$ ) at Lampedusa during the 24 to 26 June period that corresponds to a significant production of primary 

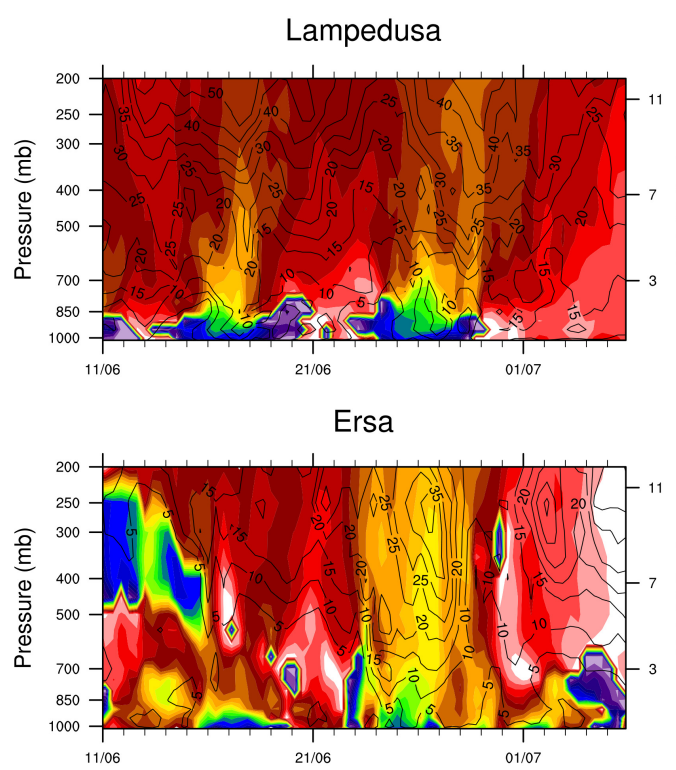

Minorca

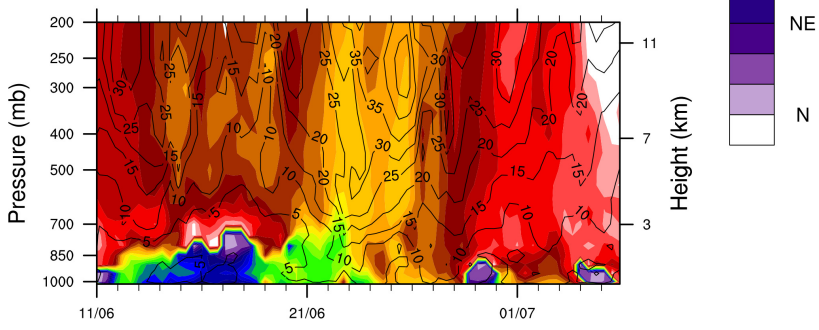

Figure 8. Wind profiles between 1000 and $200 \mathrm{hPa}$ during the SOP1a experiment for three different sites (Ersa, Lampedusa and Minorca) simulated from the ALADIN-Dust model. The wind intensity (in $\mathrm{ms}^{-1}$ ) is also reported at the different stations.

marine aerosols. Finally, the $\mathrm{PM}_{1}$ concentration at Ersa is found to be almost constant during the period of the campaign, with a mean value of $6 \mu \mathrm{g} \mathrm{m}^{-3}$. In order to take into account the difference of altitudes between the two sites of Lampedusa and Ersa, we have applied a correction factor to $\mathrm{PM}_{10}$ observed at Ersa $(530 \mathrm{~m})$ for estimating a new $\mathrm{PM}_{10}$ concentration corresponding to the altitude of Lampedusa. In that sense, we have applied the logarithmic law reported by Piazzola et al. (2015) using a value of 0.75 for the factor $\mathrm{s}$ to correct the mass concentration of sea-spray aerosols only. The calculated mean value of $\mathrm{PM}_{10}$ is about $12 \mu \mathrm{g} \mathrm{m}^{-3}$ (Fig. 13), closer to the mean value observed at Lampedusa $\left(21 \mu \mathrm{g} \mathrm{m}^{-3}\right)$. In addition, the background aerosol number concentrations (for $\mathrm{Dp}>0.01 \mu \mathrm{m}$ ) observed within the boundary layer in Corsica averaged $\sim 2000 \mathrm{~cm}^{-3}$ (not shown). The lowest concentrations $\left(\sim 200 \mathrm{~cm}^{-3}\right)$ resulted from aerosol activation to cloud droplets, and scavenging from cloud droplets and rain drops, while high concentrations as high as $10000 \mathrm{~cm}^{-3}$ were observed during pollution events from continental European air masses. The number concentrations showed a diurnal cycle suggesting that the site was situated within the marine boundary layer during daytime and within the free troposphere during night-time. The analysis of the diurnal variation of the particle number size distribution further indicates that nucleation events also increased the particle number concentration during daytime, about one-third of the time (Sellegri et al., 2016). The periods of high aerosol number concentrations detected between 12 and 25 June were also dominated by a single mode with diameters between 30 and $150 \mathrm{~nm}$. The small Aitken mode $(\mathrm{dg}<50 \mathrm{~nm})$ associated with pollution events suggests a relatively fresh aerosol that has been formed during transport from the European continent. The largest mode ( $\mathrm{dg} \sim 150 \mathrm{~nm}$ ) occurred during the dust event on 18 June.

\subsubsection{Columnar particle volume size distribution}

We have used the column-integrated particle size volume distributions derived from AERONET/PHOTONS sky radiance measurements (Dubovik et al., 2000). These size distributions allow investigation of the changes in aerosol size distribution between different stations during the SOP-1a and over the western basin. Four different stations have been studied, which include the two super-sites of Lampedusa and Ersa, as well as the aircraft and balloon base stations, Cagliari and Cap d'En Font, respectively. Daily volume size distributions for both sites are represented in Fig. 14, as well as the averaged (red curve) size distribution for the whole period (1 June to 5 July) and the number of observations. In addition, the mean values of the volume radius, concentration of fine and coarse mode and the standard deviations of the volume size distribution are reported in Table 6. It should be noted that the scales of the $y$ axis are different for each figure. One can note the bimodal size distribution for both stations with large spread of radius values, especially for the coarse mode. The most important concentrations are obviously observed in Lampedusa, near the mineral dust sources, with maxima of $\sim 0.12 \mu \mathrm{m}^{3} \mu \mathrm{m}^{-2}$ for the coarse mode. In parallel, the lowest concentrations are observed at the Ersa station due to the absence of intense polluted photochemical or smoke aerosol events over southern France and Italy during the SOP-1a. In that sense, the mean contribution (red curve) of the coarse mode to the aerosol volume size distribution appears to be predominant at most sites, except at the Ersa station. However, the inclusion of the corrected factor (Piazzola et al., 2015) for taking into account the altitude of the Ersa site reduces slightly the differences in the concentration of the coarse mode with the Lampedusa station (see Table 6). This point is well noted for the Cap d'En Font station, where the concentration of each modes appear as equivalent, due to the absence of pollution from the Iberian Peninsula during the period of observations. For this site, it is interesting to note the intense peak of concentration $\left(0.08 \mu \mathrm{m}^{3} \mu \mathrm{m}^{-2}\right)$ for 27 June, which is due to the transport of an important smoke plume over the Mediterranean (see Ancellet et al., 2015; Chazette et al., 2015). Finally, the contribution of the coarse 

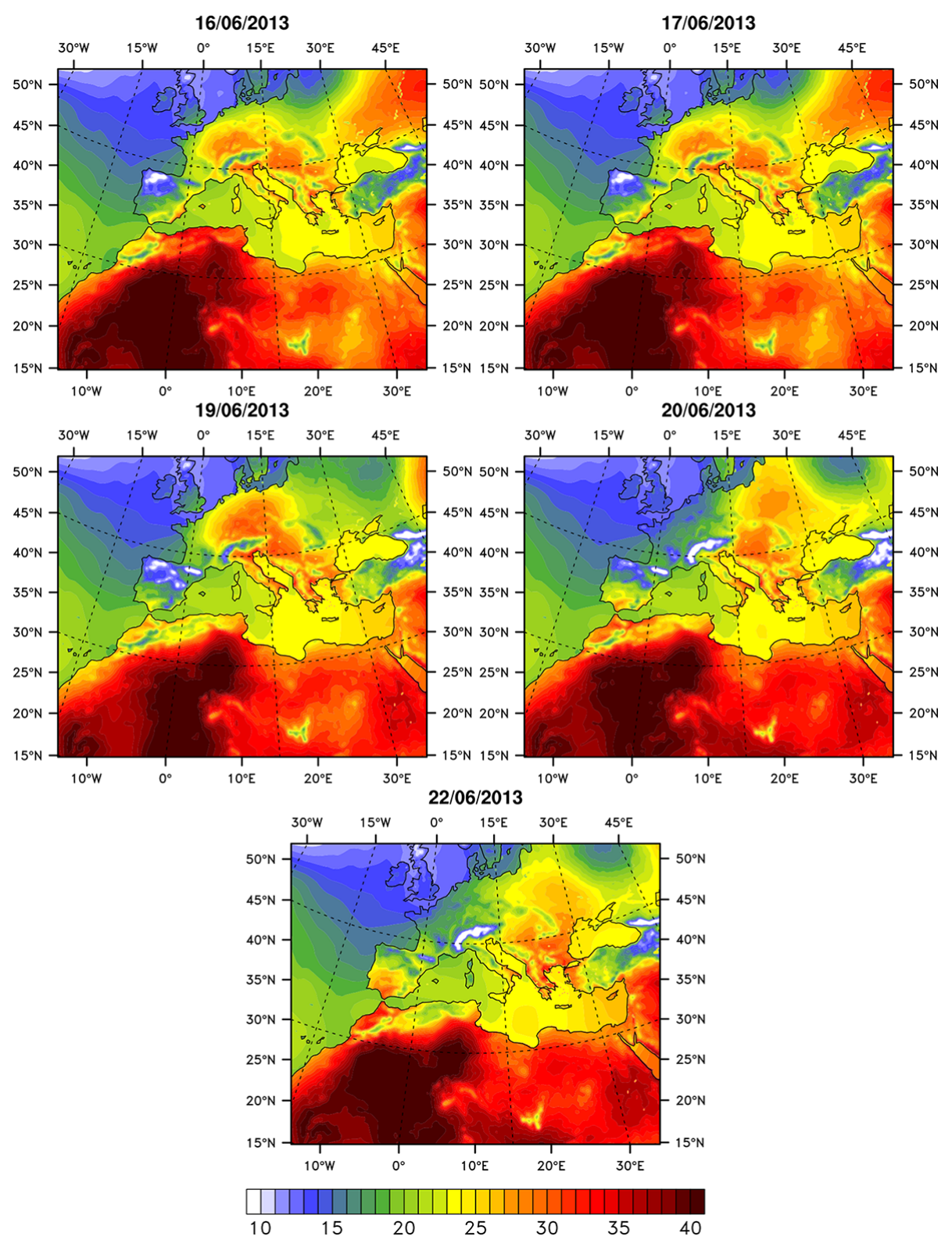

Figure 9. Surface temperature (at 12:00 UTC) obtained from NCEP re-analysis for 16, 17, 19, 20 and 22 June.

mode clearly increases for the two other, more southern Italian sites of Cagliari and Lampedusa, which are more affected by the mineral dust compared to Ersa and Cap d'En Font. The variability of AERONET products collected over a period of 4 years at Ersa and Palma de Mallorca, near Cap d'En Font, is reported in Sicard et al. (2015b). It is interesting to note the variability $( \pm 0.05)$ in the derived size of the coarse mode at Lampedusa (see Table 6), which will be analyzed with regards to dust sources in a future study. The derived volume concentrations over these two stations highlight the moderate dust activity occurring during the SOP-1a experiment, when compared to stations under high dust conditions. As an example of comparisons, Dubovik et al. (2002) reported a large range of concentration for the coarse mode for dusty sites (such as Cape Verde or Solar Village), which are characterized by larger concentrations, close to $0.30 \mu \mathrm{m}^{3} \mu \mathrm{m}^{-2}$. In parallel, the Bahrain (Persian Gulf) AERONET station is characterized by a concentration of $0.14-0.15 \mu \mathrm{m}^{3} \mu \mathrm{m}^{-2}$.

\subsubsection{Particle size distribution during transport}

Figure 15 presents an example of the evolution of the aerosol particle number concentrations in the 19 particle size classes of the LOAC instrument as measured along the northward trajectory of BPCL balloon B74 from Minorca to the French coast (see Fig. 4). The balloon was launched at 09:46 UTC on 16 June 2013 during a moderate desert dust event shown 


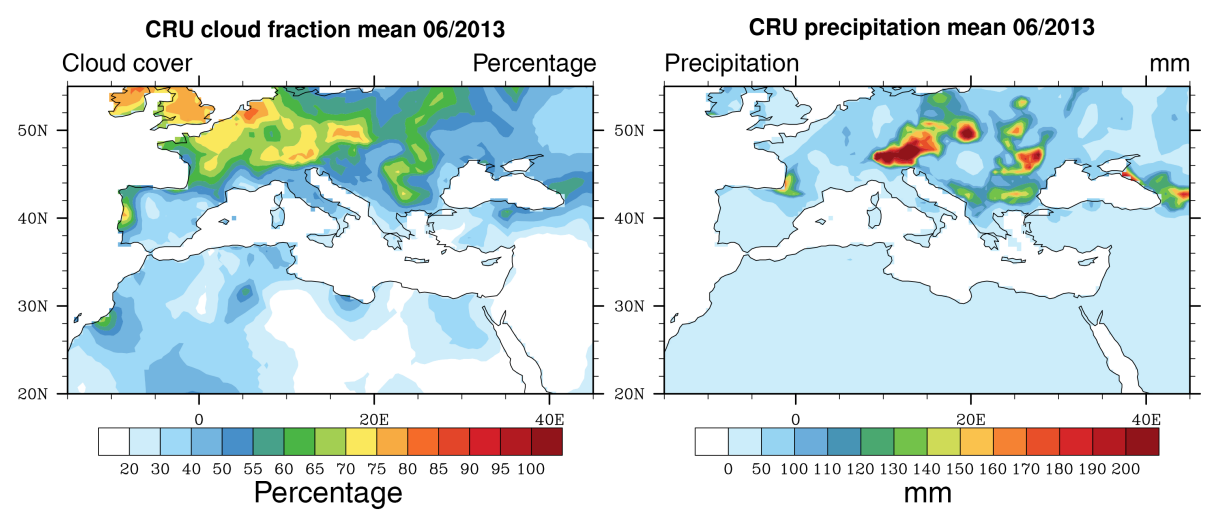

Figure 10. Monthly cloud cover and precipitation (over land only) derived from the Climate Research Unit (CRU) data for June 2013.

Table 6. Main aerosol volume size distribution characteristics: $r_{\mathrm{vf}}(\mu \mathrm{m}), \sigma_{\mathrm{f}}, r_{\mathrm{vc}}(\mu \mathrm{m}), \sigma_{\mathrm{c}}, C_{\mathrm{vf}}$, and $C_{\mathrm{vc}}$, for the four different AERONET/PHOTONS stations: Ersa, Lampedusa, Cagliari and Cap d'En Font. $C_{\mathrm{vi}}$ denotes the particle volume concentration, $r_{\mathrm{vi}}$ is the median radius, and $\sigma_{i}$ is the standard deviation. Each average value in the table is accompanied by its standard deviation (this is not an accuracy of the retrieval). As mentioned in the text, the concentration of the coarse mode at Ersa has been corrected to be comparable to results at other stations closer to the sea surface, using the logarithmic law proposed by Piazzola et al. (2015).

\begin{tabular}{|c|c|c|c|c|c|}
\hline & Ersa & Ersa corrected & Lampedusa & Cagliari & Cap d'En Font \\
\hline Number of observations & 25 & & 18 & 20 & 17 \\
\hline$r_{\mathrm{vf}}(\mu \mathrm{m})$ & $0.16 \pm 0.02$ & $\mathrm{n} / \mathrm{a}$ & $0.14 \pm 0.01$ & $0.15 \pm 0.03$ & $0.17 \pm 0.03$ \\
\hline$\sigma_{\mathrm{f}}$ & $0.43 \pm 0.03$ & $\mathrm{n} / \mathrm{a}$ & $0.50 \pm 0.06$ & $0.46 \pm 0.04$ & $0.45 \pm 0.04$ \\
\hline$r_{\mathrm{Vc}}(\mu \mathrm{m})$ & $2.49 \pm 0.43$ & $\mathrm{n} / \mathrm{a}$ & $2.36 \pm 0.48$ & $2.52 \pm 0.28$ & $2.48 \pm 0.30$ \\
\hline$\sigma_{\mathrm{c}}$ & $0.69 \pm 0.03$ & $\mathrm{n} / \mathrm{a}$ & $0.68 \pm 0.05$ & $0.71 \pm 0.04$ & $0.71 \pm 0.04$ \\
\hline$C_{\mathrm{vf}}\left(\mu \mathrm{m}^{3} / \mu \mathrm{m}^{2}\right)$ & $0.02 \pm 0.01$ & $\mathrm{n} / \mathrm{a}$ & $0.02 \pm 0.01$ & $0.02 \pm 0.01$ & $0.02 \pm 0.01$ \\
\hline$C_{\mathrm{vc}}\left(\mu \mathrm{m}^{3} / \mu \mathrm{m}^{2}\right)$ & $0.03 \pm 0.01$ & 0.04 & $0.08 \pm 0.05$ & $0.05 \pm 0.03$ & $0.04 \pm 0.03$ \\
\hline
\end{tabular}

TRMM_3B42 Precipitation - mean 06/2013

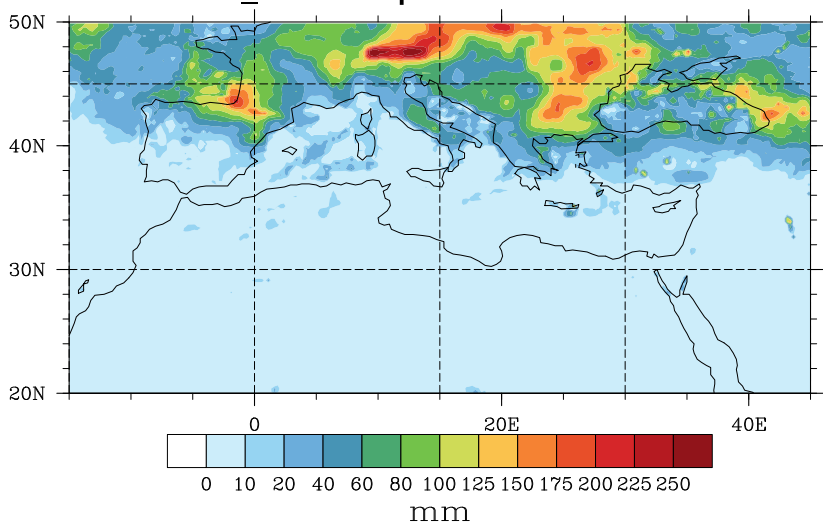

Figure 11. Same as Fig. 10 but for the Tropical Rainfall Measuring Mission (TRMM) precipitation observations.

at the top of Fig. 6 (AERONET-derived AOD at $550 \mathrm{~nm}$ of 0.15 ). It drifted at a constant altitude of $\sim 2.1 \mathrm{~km}$ at the bottom of the African dust layer observed with the WALI lidar at Minorca (not shown; see Chazette et al., 2015), and was automatically forced to land on the sea before reaching the coast south of Marseilles, after a $12 \mathrm{~h}$ flight of $368 \mathrm{~km}$. The dominant mineral dust nature of the particles was confirmed by the LOAC particle typology measurements (Renard et al., 2015b). The figure illustrates that LOAC has detected large particles of up to $50 \mu \mathrm{m}$ in diameter, although the plume originated from northern Africa a few days before (Renard et al., 2015b). The concentrations of particles remained relatively constant during the flight, suggesting either no significant sedimentation of the largest particles during the flight or compensation by particles coming from above. BPCL balloon B70 launched a few minutes later drifted at an upper altitude of $\sim 3.1 \mathrm{~km}$ and followed a different trajectory towards the east (Fig. 4), but showed a quite similar extended particle size range with larger concentrations in almost all channels except the extremes (not shown). The four other drifting balloons launched in the dust layer during this event on 17 and 19 June (Table 5) did confirm the presence of very large particles $(>20 \mu \mathrm{m})$, which cannot be reported by the AERONET particle size distribution retrieval algorithm (Hashimoto et al., 2012). In addition, observations of large particles $(>15 \mu \mathrm{m})$ were systematically found during 


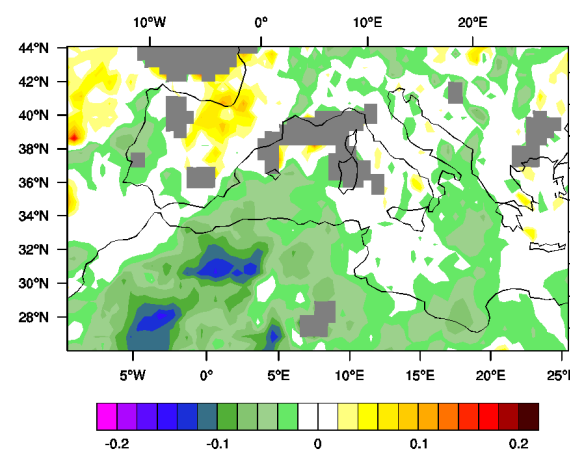

MISR observations

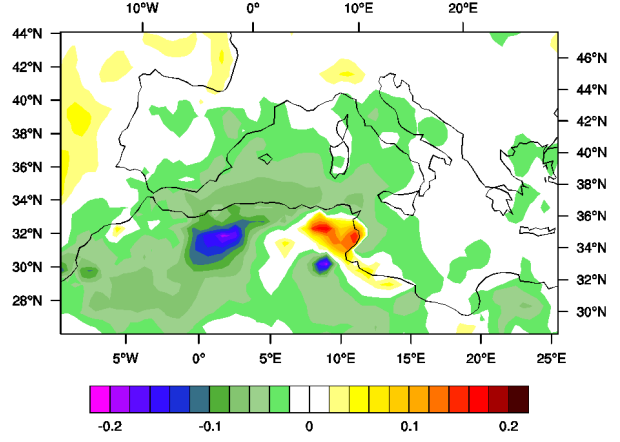

MODIS observations

Figure 12. AOD $(550 \mathrm{~nm})$ anomaly for summer 2013 estimated from the MODIS and MISR sensor data.

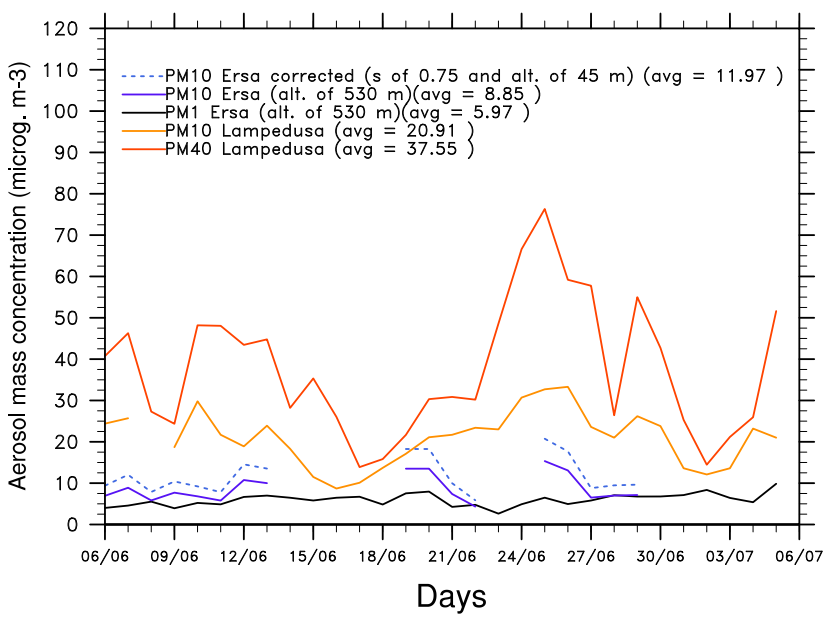

Figure 13. Time series of daily $\mathrm{PM}$ mass concentrations estimated at the Lampedusa $\left(\mathrm{PM}_{40}\right.$ and $\left.\mathrm{PM}_{10}\right)$ and Ersa $\left(\mathrm{PM}_{1}\right.$ and $\left.\mathrm{PM}_{10}\right)$ super-stations. Problems in $\mathrm{PM}_{10}$ data acquisition that occurred at Ersa explain the gaps. $\mathrm{PM}_{10}$ Ersa corrected curves correspond to $\mathrm{PM}_{10}$ estimated at an altitude of $45 \mathrm{~m}$ to be comparable with Lampedusa results, following the logarithmic law provided by $\mathrm{Pi}$ azzola et al. (2015) (see text in Sect. 5.1.1 for details).

all other LOAC balloon flights drifting in African dust layers, which will need further analysis to better understand the process that can maintain such large particles in suspension during several days.

Concerning the aerosol microphysical properties, aircraft observations have allowed us to investigate the vertical structure of aerosol size distribution showing particles characterized by large sizes ( $>10 \mu \mathrm{m}$ in diameter) within dust plumes. In addition, in most of the cases, a coarse mode of mineral dust particles, characterized by an effective diameter $D_{\text {eff,c }}$ ranging between 5 and $10 \mu \mathrm{m}$, has been detected within the dust layer located above the MBL. Such values are found to be larger than those referenced in dust source regions during FENNEC, SAMUM1 and AMMA, as well as measure- ments in the Atlantic Ocean in the Cape Verde region during SAMUM-2 and at Puerto Rico during PRIDE. The complete analysis of aerosol size distribution is detailed in Denjean et al. (2015).

\subsubsection{Aerosol chemical composition}

In terms of aerosol chemical properties, an example of averaged mass size distributions for carbonaceous (elemental and organic carbon, EC and OC) species (mass size distributions of inorganic and mineral dust aerosols are not shown) obtained at Ersa from a 12-stage cascade impactor (DEKATI system; see Table 1) is reported in Fig. 16. The aerosol chemical properties obtained from the PILS instrument at Ersa are detailed in Claeys et al. (2016). As mentioned in Table 1, the measurements were obtained by using a 2-day collection period in order to obtain a sufficient aerosol mass on filters for chemical analyses. This system provides the speciation of the mass size distribution, including fine and coarse fractions. Such information is very useful for deriving optical properties using Mie calculations (Mallet et al., 2011) for the main particle types (sulfates, ammonium, nitrates, sea spray, dust, black and organic carbon). This provides crucial information on key radiative properties that are classically used in regional climate models (mass extinction efficiencies, SSA and asymmetry parameter). Furthermore, it allows one to assess the spectral dependence of radiative properties, which cannot always be estimated from in situ instrumentation.

Concerning OC (blue curves), observations clearly report a bi-modal mass size distribution with two different peaks for the majority of cases. The first (almost constant) peak is found in the $0.4-0.5 \mu \mathrm{m}$ size range in diameter and more occasionally a second one occurs in the coarse fraction around $3 \mu \mathrm{m}$. Compared to the few available data over the western Mediterranean, these mass size distributions are found to be different from those obtained over southern France, especially for the accumulation mode. Indeed, during the ESCOMPTE experiment in southern France, Mallet 


\section{SOP-1a AERONET/PHOTONS Volume size distribution}
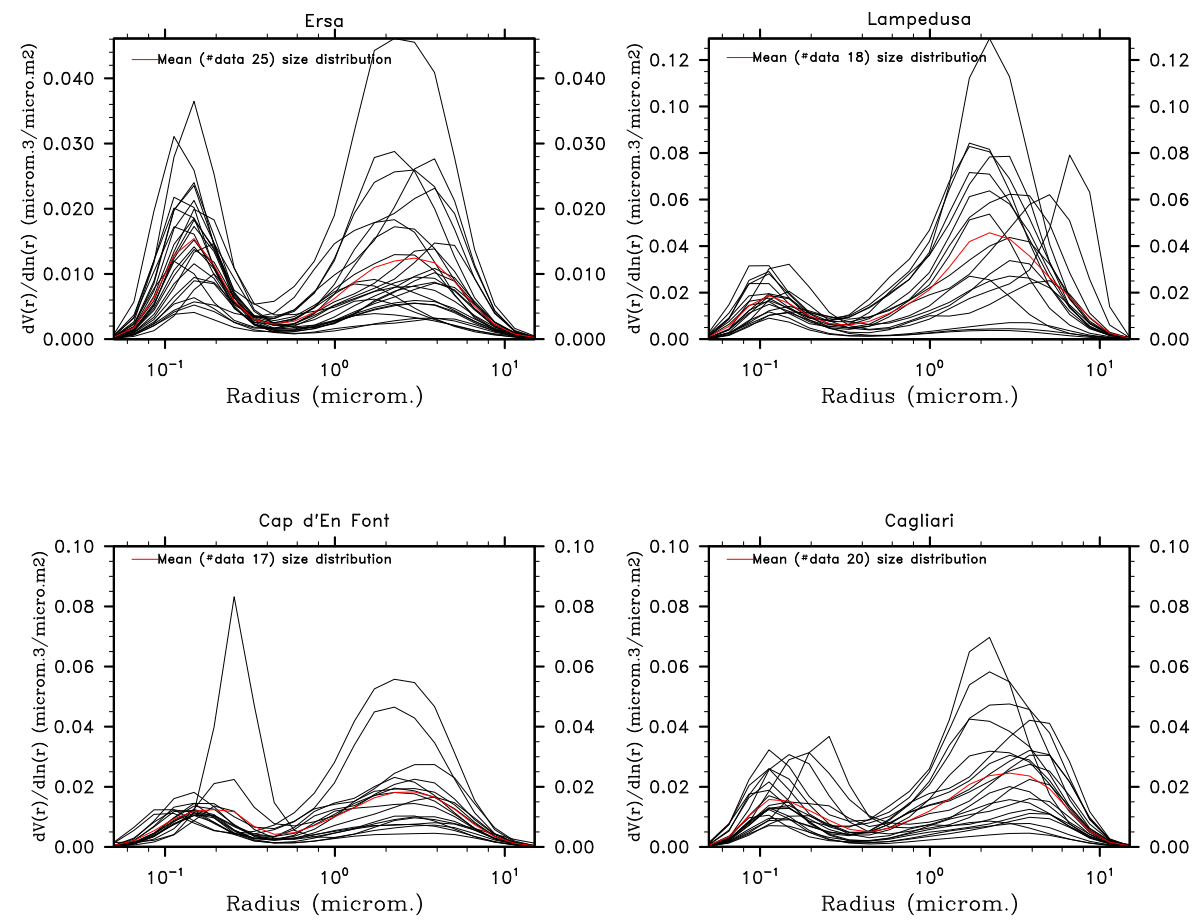

Figure 14. AERONET/PHOTONS volume size distribution derived at four different stations: Ersa, Lampedusa, Cagliari and Cap d'En Font (the red curve represents the mean of observations). The characteristics of the volume size distribution are provided in Table 6.

et al. (2003) also observed a bi-modal size distribution for OC aerosols but with a finer accumulation mode observed in the $0.1-0.2 \mu \mathrm{m}$ size range. Differences between the two observations is likely due to the proximity of anthropogenic sources during the ESCOMPTE experiment compared to the Ersa station, where the possible ageing of carbonaceous particles could affect the size of aerosols. On the contrary, the coarse mode of OC appears in the same range of size, around $3 \mu \mathrm{m}$, for both experiments. Compared to data obtained in the eastern Mediterranean basin, the OC mass size distributions are in good agreement with those estimated by Sciare et al. (2003) in Crete during the MINOS campaign, with two modes around 0.4 and $3 \mu \mathrm{m}$. The EC (green curves in Fig. 16) mass size distribution is also characterized by a bi-modal size distribution, with two modes well correlated with the mass size distribution of OC, except for the 16-19 June period (dust episode), where the size of EC fine mode is higher $(\sim 0.5-0.6 \mu \mathrm{m})$ than $\mathrm{OC}$ aerosols, the EC coarse mode remaining similar at $\sim 3 \mu \mathrm{m}$. This reveals a possible external mixing of carbonaceous aerosols for this event.

It should also be noted that the EC concentrations observed at the Ersa station are logically (due at least to the altitude of the station and the absence of intense pollution during the SOP-1a; see Sect. 4) lower $\left(0.39 \mu \mathrm{g} \mathrm{m}^{-3}\right)$ than EC concentrations $\left(\mathrm{PM}_{2.1}\right)$ reported by Eleftheriadis et al. (2006) from the eastern Mediterranean during the summer season $\left(0.6 \mu \mathrm{g} \mathrm{m}^{-3}\right)$ in July 2000 . The same ascertainment is obtained on OC concentrations with higher values $\left(4.2 \mu \mathrm{g} \mathrm{m}^{-3}\right)$ reported by Eleftheriadis et al. (2006) compared to observations at Ersa $\left(1.5 \mu \mathrm{g} \mathrm{m}^{-3}\right)$. Concerning the modes of the OC and EC particle mass size distributions, the two identified modes detected in Ersa are consistent with those reported by Mallet el al. (2011) at the Porquerolles coastal island (southeastern France), who also detected two (fine and coarse) different modes of the mass size distributions for EC $(0.3-0.4$ and $4-6 \mu \mathrm{m})$ and $\mathrm{OC}(0.3$ and 5-6 $\mu \mathrm{m})$ aerosol particles. In most cases, we observed at Ersa lower concentrations of EC particles for both modes compared to OC aerosols. The mass of OC and BC observed during the SOP-1a, for both modes, are found to be equivalent with those observed by Sciare et al. (2003) in Crete in summer 2001. They report mean values of 0.30 and $0.15 \mu \mathrm{g} \mathrm{m}^{-3}$ for fine OC and $\mathrm{BC}$, respectively. During the MINOS experiment, the mean concentrations for $\mathrm{OC}$ and $\mathrm{BC}$ coarse modes were about 0.1 and $0.02-0.03 \mu \mathrm{g} \mathrm{m}^{-3}$, what is also consistent with the observations at Ersa. Finally, the mass concentrations obtained for each mode at Ersa are logically lower than those obtained during the ESCOMPTE experiment, located much closer to pollution sources. For example, EC and OC fine-mode concentrations were, respectively, between 0.8 and $2.8 \mu \mathrm{g} \mathrm{m}^{-3}$ and between 3.1 and $6.9 \mathrm{\mu g} \mathrm{m}^{-3}$ during ESCOMPTE (Mallet et al., 2003). In addition, and as discussed in Sects. 4.1 and 

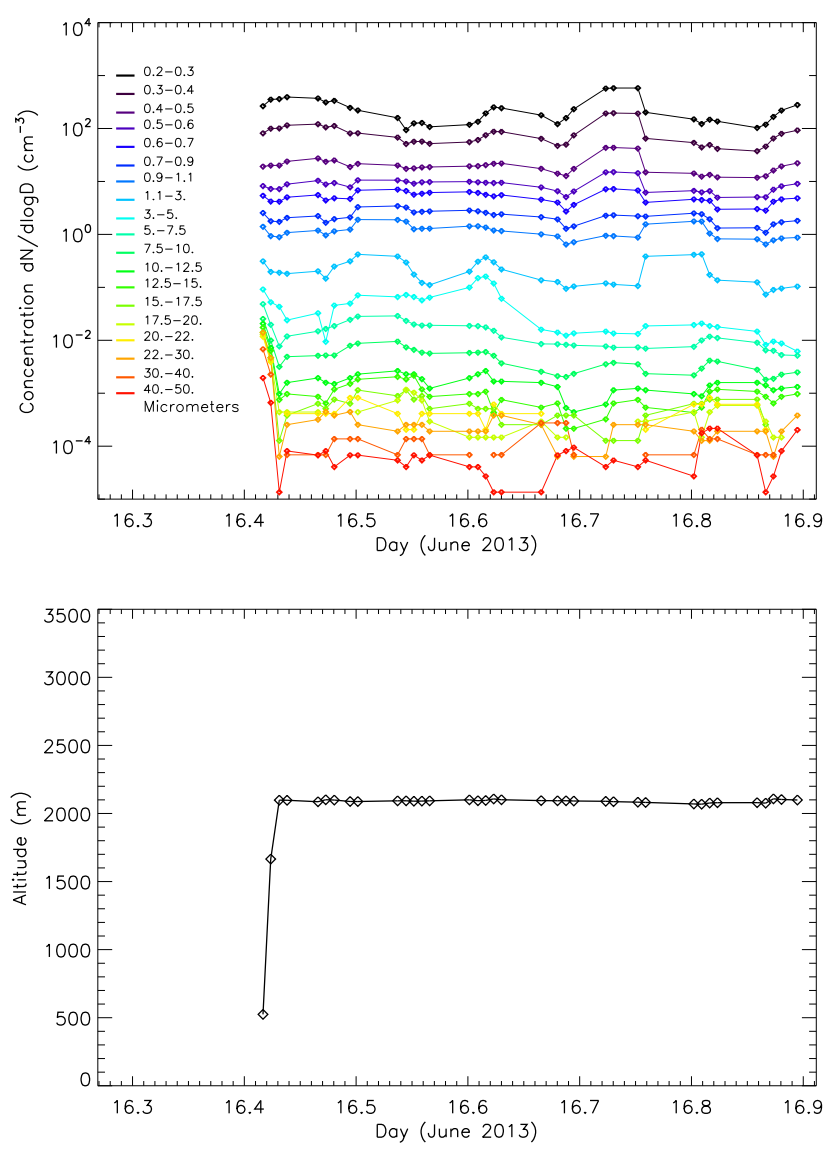

Figure 15. Particle size distribution measured with a LOAC during the $\sim 12 \mathrm{~h}$ flight of BPCL balloon B74 drifting from Minorca towards Marseilles (see the trajectory in Fig. 4). The first and last 20 min correspond to the ascending and descending phases of the quasi-Lagrangian flight that occurred at a constant altitude of $2091 \pm 10 \mathrm{~m}$.

4.2, the meteorological conditions (surface temperature, meteorological synoptic situations) observed during the SOP1a campaign were not favorable to producing large concentrations of polluted or smoke aerosols, compared to the ESCOMPTE campaign, where AOD as large as 0.3-0.5 (in the visible range) has been observed due to important concentrations of anthropogenic-polluted particles. It should be noted that, in parallel to filter analyses, higher time-resolved observations from the PILS systems have been deployed at the two stations of Lampedusa and Ersa (Claeys et al., 2016) during the SOP-1a.

In parallel to filter chemical analysis, over 700000 single particle mass spectra were generated by the A-TOFMS instrument during the sampling period (not shown). A $K$ means algorithm $(K=80)$, as described in detail by Healy et al. (2010) and Gross et al. (2010), was used to classify aerosol mass spectra into different particle classes. More than 40 distinct ATOFMS particle classes were identified and subsequently grouped into 8 general categories for clar-
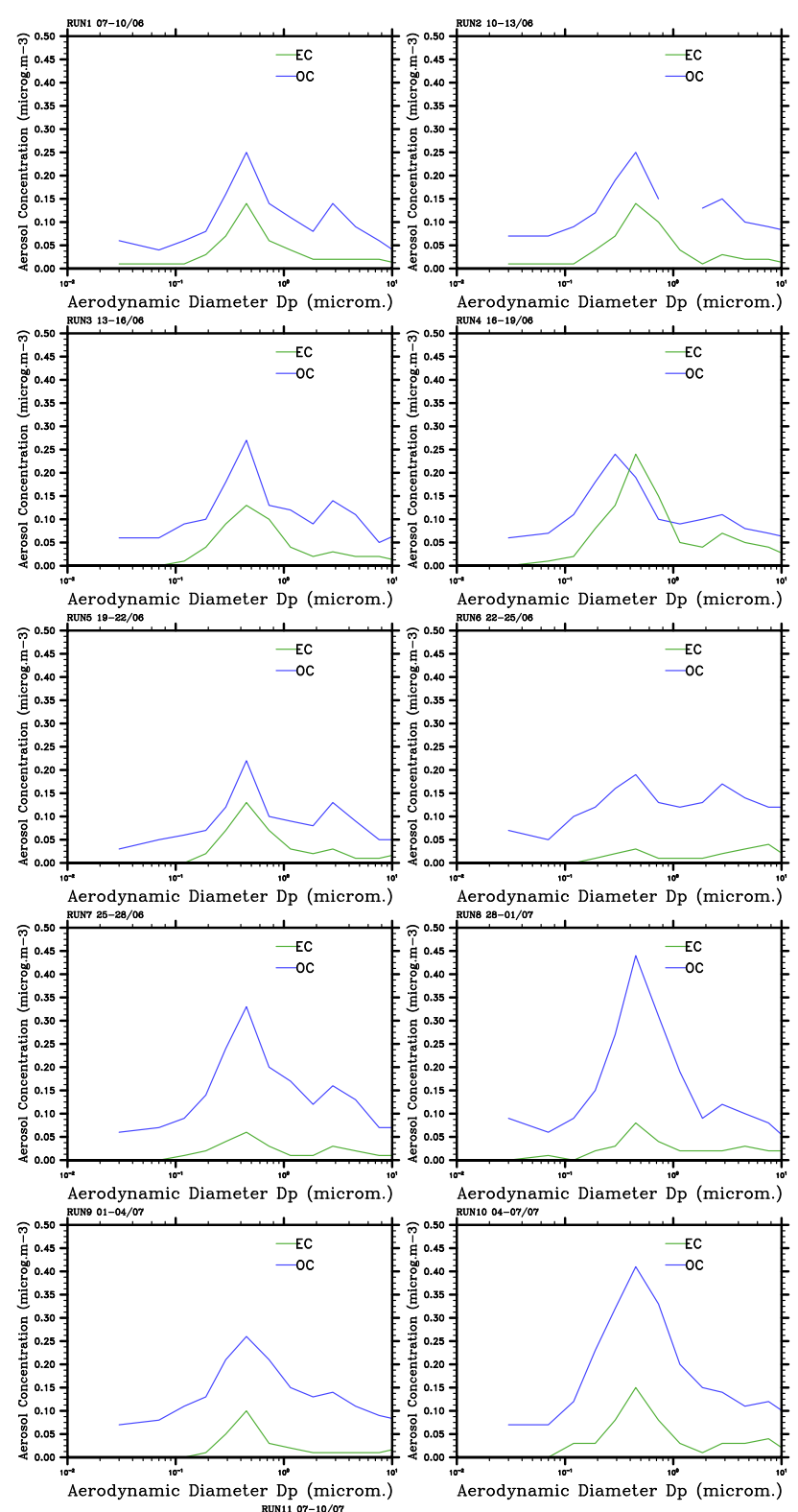

Aerodynamic Diameter Dp (microm.)

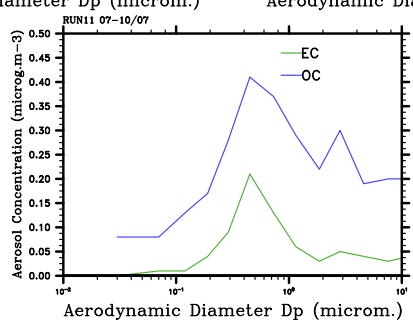

Figure 16. EC and OC ( $48 \mathrm{~h}$ mean) aerosol mass size distributions obtained at Ersa from the DEKATI impactor instrument for the entire SOP-1a period.

ity. Elemental carbon-containing particles dominated the data set $(55 \%$ of total spectra), followed by $K$-rich particles $(30 \%)$ and sea spray $(7 \%)$. The remaining particle categories include organic carbon (OC)-containing (3\%), 


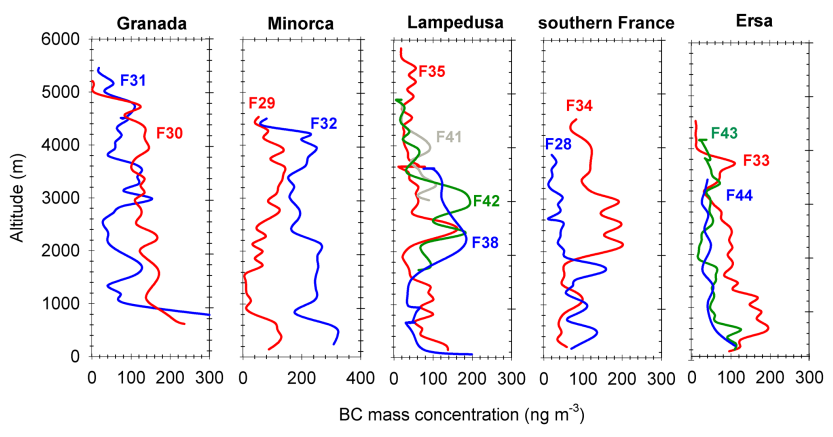

Figure 17. Vertical profiles of $\mathrm{rBC}$ concentrations estimated from the SP2 instrument for five different zones (Granada, Minorca, Lampedusa, southern France and Ersa).

trimethylamine (TMA)-containing (3\%), shipping (2\%), Fecontaining $(0.5 \%)$ and Ca-containing $(0.3 \%)$. EC particles dominated the first third of the sampling period, decreased noticeably for approx. 6 days and then dominated the rest of the sampling period again. In contrast, $K$-rich particle (associated with biomass burning and dust) numbers were high only for the latter half of the campaign, with a peak on $27-$ 28 June. The profiles of these two particle categories suggest transport from regional sources. Sea-spray particle numbers were at their highest during the period where EC particles were at their lowest, and were generally low when EC particle numbers were high. OC-containing particles were present during the same period $K$-rich numbers peaked, suggesting an association with the transport of biomass burning particles. TMA particles were present in low numbers throughout the sampling period, suggesting a less regional source, independent of the air masses influencing EC and sea-spray particle occurrence. The same can be said of Fe- and $\mathrm{Ca}$ containing particles, likely to be local dust, while shipping particle numbers were slightly higher during the first half of the sampling period.

Finally and concerning the aerosol chemical properties, an interesting aspect of the obervations deployed during the SOP-1a concerns the rBC concentrations obtained from the SP2 instrument onboard the ATR-42. Despite its importance, studies on $\mathrm{rBC}$ were until now limited to surface-based measurements in the Mediterranean region. Measurements of vertical distribution of $\mathrm{rBC}$ concentrations provide crucial information for assessing the $\mathrm{rBC}$ radiative effects in the region. Figure 17 shows the vertical distributions of $\mathrm{rBC}$ mass concentrations measured by the SP2 in the five areas (Granda, Minorca, Lampedusa, southern France and Ersa). For the different vertical soundings, $\mathrm{rBC}$ mass concentrations ranged between 20 and $690 \mathrm{ng} \mathrm{m}^{-3}$ close to the surface. The surface $\mathrm{rBC}$ concentrations were generally less than $200 \mathrm{ng} \mathrm{m}^{-3}$, typical for continental and regional background sites in the western Mediterranean basin (Ripoll et al., 2015). The lowest surface concentrations of $\mathrm{rBC}\left(\sim 20 \mathrm{ng} \mathrm{m}^{-3}\right)$ were found in southern France over the open sea, with al- most no local contribution of anthropogenic aerosols. Maxima surface concentrations $\left(\sim 690 \mathrm{ng} \mathrm{m}^{-3}\right)$ were recorded over Granada where frequently heavy traffic emissions are occurring. These observations were obtained between 07:15 and 07:45 UTC, when the convection was not fully developed, which probably did not favor the vertical transport of local emissions over Granada. A prominent feature in vertical profiles is the presence of significant concentrations of $\mathrm{rBC}$ up to 5-6 km altitude. Therefore the regional transport of $\mathrm{rBC}$ particles was not only limited to the MBL but occurred also at higher altitude. In most of the observed cases, the $\mathrm{rBC}$ vertical distribution in the free troposphere reveals a strongly stratified structure characterized by either single isolated plumes or more uniform layers. It is worth noting the presence of $\mathrm{rBC}$ layers above the MBL in the open sea that could be attributed to convective transport from distant sources. Only in few observed cases, rBC mass concentration decreased monotonically with increasing altitude, most likely due to vertical transport of air masses from surface to higher heights.

\subsection{Aerosol optical properties}

\subsubsection{In situ optical properties at the surface}

Figure 18 reports the (daily mean) time series of nephelometer observations obtained at the surface for the Ersa and Lampedusa stations. Daily scattering coefficients (at the three nephelometer wavelengths of 450,550 and $700 \mathrm{~nm}$ ) are reported, as well as the scattering Angström exponent (AE) calculated between 450 and $700 \mathrm{~nm}$. At $550 \mathrm{~nm}$ and at Ersa, the scattering coefficient presents a significant variability during the SOP-1a, with peaks of about $35-40 \mathrm{Mm}^{-1}$ during the dust event (19-20 June) transported over Corsica, associated with low values $\left(15 \mathrm{M} \mathrm{m}^{-1}\right)$ for certain periods of time, as for 21-22 June. The mean scattering coefficient (at $550 \mathrm{~nm}$ ) is $24 \mathrm{Mm}^{-1}$. Such scattering coefficient values are comparable to observations reported by Vaishya et al. (2012) at the Mace Head station for Atlantic marine air, with scattering coefficient (at $550 \mathrm{~nm}$ ) ranged between 10 and $25 \mathrm{M} \mathrm{m}^{-1}$ during the summer period. In terms of scattering spectral dependence, the calculated scattering $\mathrm{AE}$ is found to be almost constant, with $\mathrm{AE} \sim 1.5-2$ and a mean value of 1.71 (indicating that scattering is mostly dominated by fine aerosols) during the SOP-1a, except for 23-24 June. The lowest values $(\mathrm{AE} \sim 0.3-0.5)$ observed during this period are the result of a large contribution of coarse sea-spray aerosols (Claeys et al., 2016) due to moderate $\left(5 \mathrm{~m} \mathrm{~s}^{-1}\right)$ westerly winds (see Fig. 8) at the Ersa station, which is also observed from the filter chemical size-resolved analyses and detected on the ATOFMS and VHTDMA data. In parallel, we observe that the dust event occurring in Ersa on 18-20 June is not correlated with low scattering $\mathrm{AE}$, revealing a possible contribution of fine dust particles only to scattering, the result of a possible deposition of the coarse dust fraction during transport. The 
AERONET-derived AE between 440 and $870 \mathrm{~nm}$ shows values $<1$ in the afternoon of 19 June and early morning of 20 June suggesting that coarse dust is present in the column. At Lampedusa, the daily scattering coefficient (at $550 \mathrm{~nm}$ and from $\mathrm{PM}_{40}$ inlet) is between 20 and $90 \mathrm{Mm}^{-1}$ (mean value of $50 \mathrm{M} \mathrm{m}^{-1}$ ), which is twice higher than at Ersa (Fig. 18). The scattering AE was also highly variable, with values ranging between 0.5 and 2.5 (mean value of 1.1). The range of variability of these values is due to the observed switch from clean air masses strongly impacted by marine emissions to polluted air masses of various ages, including very aged/processed air masses from northern Europe. A single intrusion of mineral dust at the site was recorded on 9 June as a result of a cyclone-type of transport from Tunisia (Formenti et al., 2016).

\subsubsection{Remote-sensing observations from the surface}

The optical properties obtained from sun-photometer observations for different AERONET/PHOTONS sites are shown in Fig. 19. The AERONET/PHOTONS stations have been chosen as located in a domain encompassing most of the SOP-1a in situ and remote-sensing observations (Fig. 3), and they are characterized by different aerosol regimes (see Table 2). The total AOD, Absorbing Aerosol Optical Depth (AAOD), AOD for the fine (AODf) and coarse (AODc) modes of the volume size distribution, are indicated (at $440 \mathrm{~nm}$ ) for 11 AERONET/PHOTONS stations (Table 2). As mentioned previously, the AOD time series reveal moderate values, never reaching values as large as reported during the summer 2012 ChArMEx/TRAQA SOP-0 experiment (Rea et al., 2015). During summer 2013, the AOD was generally comprised between 0.1 and 0.7 (at $440 \mathrm{~nm}$ ) for most of the AERONET/PHOTONS sites. Over the western basin, the Granada, Minorca and Barcelona sites display the largest values during the transport of dust aerosols as detected by satellite remote-sensing observations (Fig. 6) for 16 to 20 June. During this dust event, the contribution of fine and coarse modes to the total extinction AOD is equivalent. Over the central basin, Lampedusa data reveal various peaks. The largest AOD was measured on 6 June (about 0.84 at $440 \mathrm{~nm}$ ) and 8 June (about 0.63 at $440 \mathrm{~nm}$ ). Other peaks occurred around 22 June and 1-2 July, with corresponding AOD of about $0.30-0.40$ (at $440 \mathrm{~nm}$ ), with again an equivalent contribution of each mode of the volume size distribution to the AOD. On 27-28 June, an AOD peak was also observed over most of the sites and corresponded to the transport of an aged smoke plume from the Canadian continent. In this specific case, AOD was comprised between 0.25 and 0.50 (at $440 \mathrm{~nm}$ ). Contrarily to the dust events, the contribution of the different modes to AOD was significantly different during this episode. Indeed, as shown in Fig. 18, AOD was mostly controlled by the fine mode of the volume size distribution. This specific biomass burning case is more deeply analyzed by Ancellet et al. (2015) and Chazette et al. (2015).

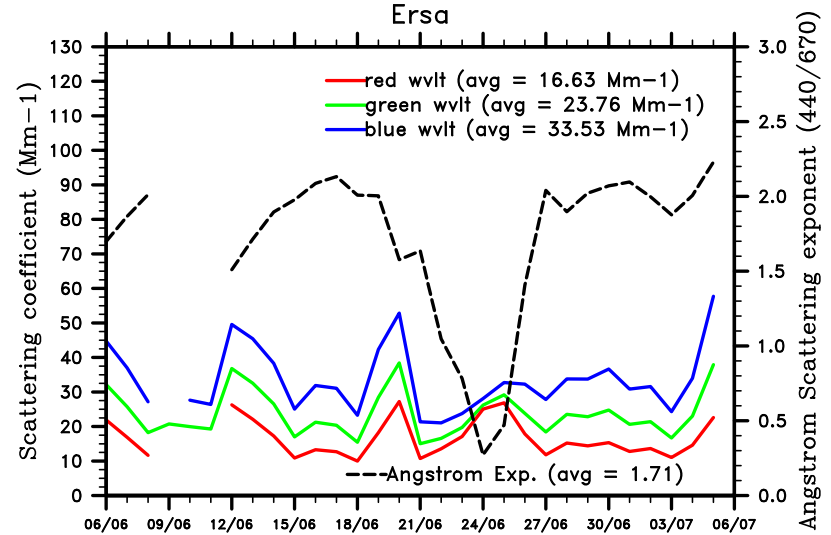

Days
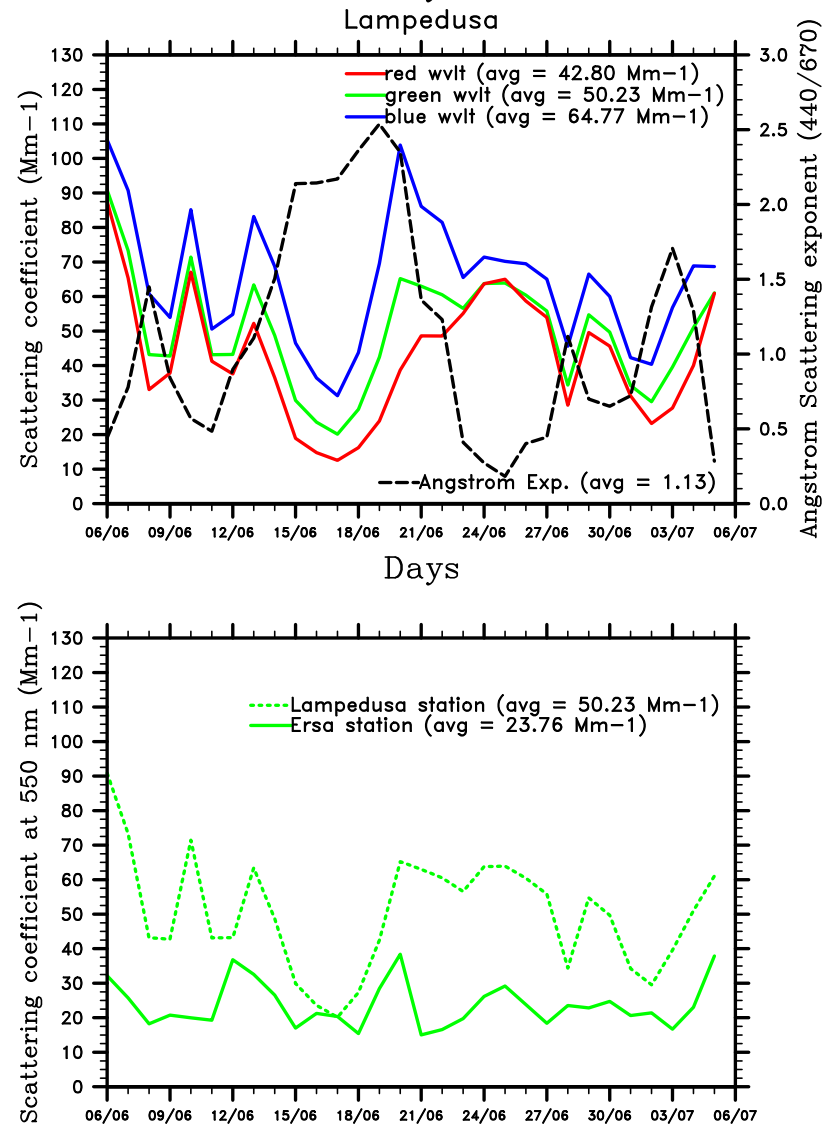

Days

Figure 18. Time series of the daily scattering coefficient (in $\mathrm{Mm}^{-1}$ ) estimated at the Ersa and Lampedusa stations. The daily Angström exponent (AE), calculated between 440 and $670 \mathrm{~nm}$, is also reported.

We have also used the SSA data set for making comparisons of its optical parameters between different stations. As for the size distributions, we have analyzed the data set in four stations, which are Ersa, Lampedusa, Cap d'En Font and Cagliari, which represent, respectively, three of the different surface stations affected by different aerosol regimes and the 

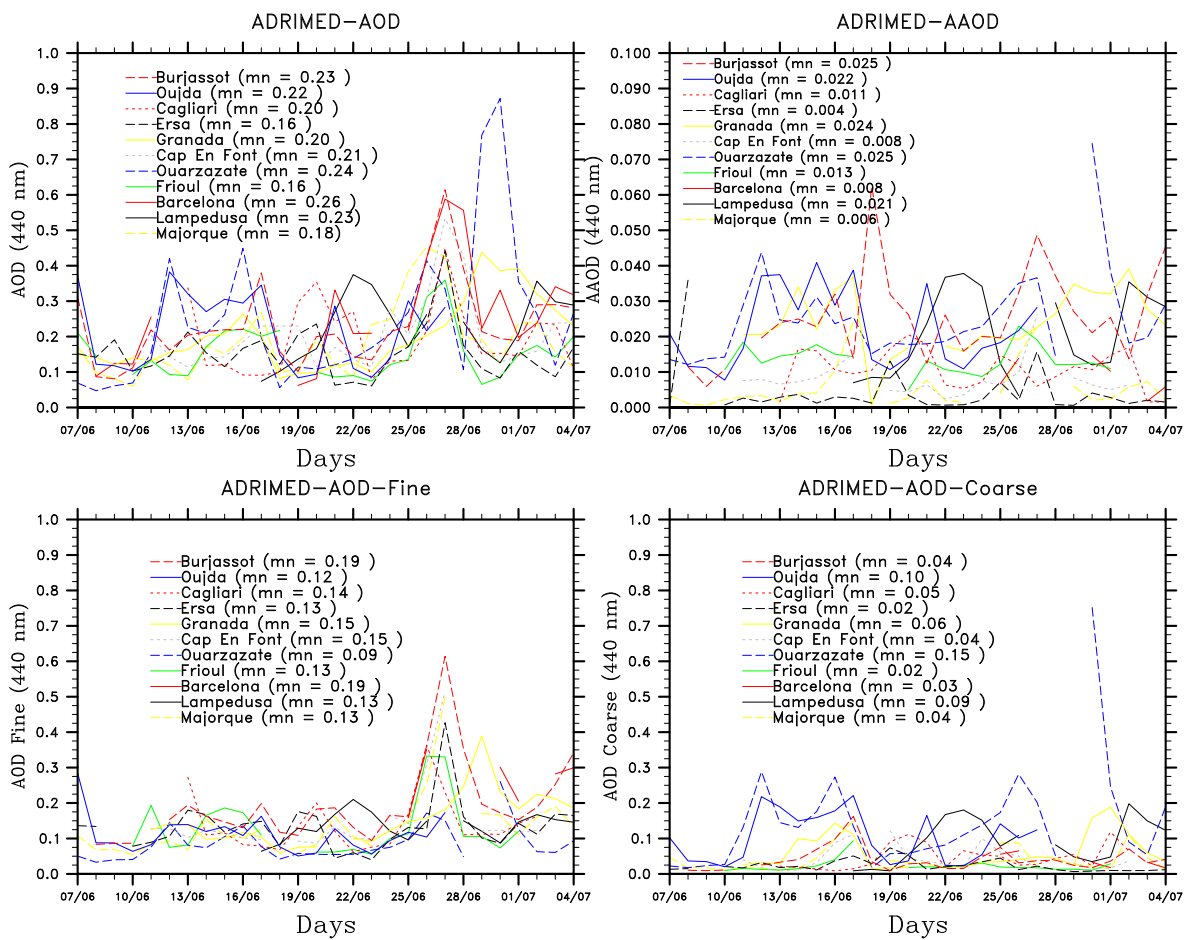

Figure 19. AERONET/PHOTONS observations of the total extinction AOD, AOD Fine (AODf), AOD Coarse (AODc) and Absorbing AOD (AAOD), at $440 \mathrm{~nm}$ obtained for the whole SOP-1a period.

aircraft locations (Cagliari). All (daily) SSA retrievals associated with the mean values (at the four wavelengths) are included in Fig. 20. Due to the moderate AOD over the period, we used Level 1.5 AERONET/PHOTONS products. In that sense, one should be reminded that uncertainties associated with SSA retrievals are important, about \pm 0.07 as reported by Dubovik et al. (2000). The results indicate an important variability of SSA and its spectral dependence over the different stations. At $440 \mathrm{~nm}$, the mean SSA is comprised between 0.91 and 0.98 , with the lowest (highest) value observed in Lampedusa (Ersa). Hence, aerosols appear as mainly scattering at Ersa and moderately absorbing at Lampedusa. The contribution of the coarse mode to the total size distribution could explain the lower values observed in Lampedusa at this wavelength. Indeed, the radiative effects and optical properties of dust are strongly dependent on the coarse mode size distribution as the larger particles appreciably decrease the SSA (McConnell et al., 2010; Otto et al., 2009). More recently and during the FENNEC experiment, Ryder et al. (2013) have calculated SSA (at $550 \mathrm{~nm}$ ) for dust aerosols using the full range of sizes measured, indicating that dust SSA was highly sensitive to effective diameter: size distributions with the largest effective diameters produced the lowest SSA values. The presence of a coarse mode could also be due to the presence of marine aerosols within the MBL in Lampedusa. Observations for the Cap d'En Font and Cagliari stations reveal an intermediate value $(0.93$ at $440 \mathrm{~nm})$ in
Cagliari, which is also more affected by mineral dust aerosols (Fig. 14). We can also observe very low values in Cagliari (for the period of 14 to 17 June) that could be due to local pollution. Anyway, one should be reminded that those retrievals have been performed under low AOD $(\sim 0.10$ at $440 \mathrm{~nm}$ ) conditions and are associated with large uncertainties. One important point concerns the changes in the SSA spectral signature between the Ersa (negative tendency between 440 and $1020 \mathrm{~nm}$ ) and Lampedusa (positive) stations. This observation is consistent with AERONET/PHOTONS data analyzed for a long-time period over the Mediterranean by Mallet et al. (2013), who report different spectral variations in SSA, following the aerosol regime (dusty and/or polluted particles). One of the main conclusions here is that aerosols are found to be moderately absorbing during the SOP-1a period, what is consistent with in situ observations performed onboard the ATR-42 aircraft and summarized by Denjean et al. (2015).

\subsubsection{ATR-42 and F-20 aircraft observations}

In parallel to surface observations, an example of the vertical profiles of aerosol optical properties obtained from ATR42 measurements is shown in Fig. 20 that corresponds to flights 35-36 over the station of Lampedusa for 22 June (see also Denjean et al., 2015; Nicolas et al., 2016). Scattering coefficients (in $\mathrm{Mm}^{-1}$ ) are plotted at 450, 550 and $700 \mathrm{~nm}$ (left) versus altitude (in meters). Completely different behaviors 


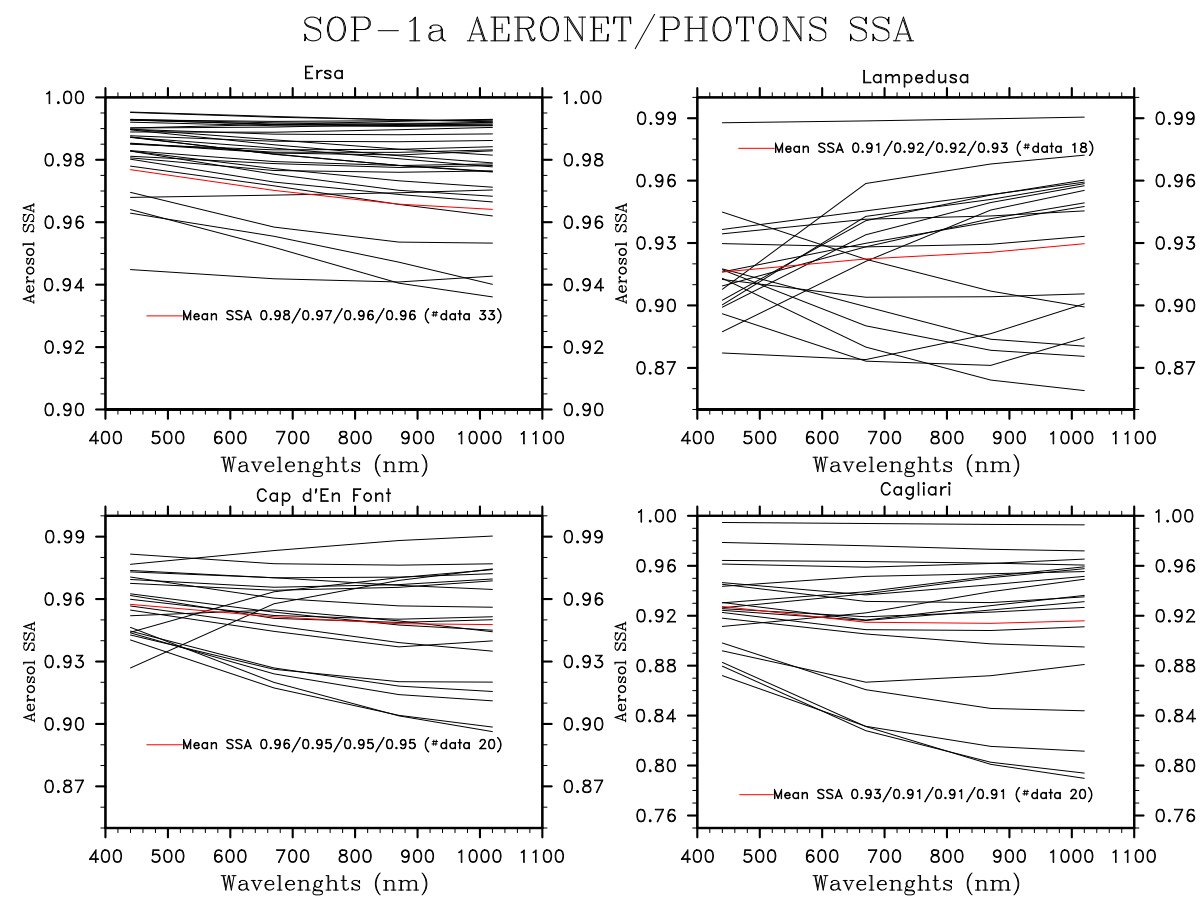

Figure 20. AERONET/PHOTONS observations (Ersa, Lampedusa, Cap d'En Font and Cagliari) of the total single scattering albedo (SSA) at 440,670, 880 and $1020 \mathrm{~nm}$ obtained for the whole SOP-1a period (the red curve represents the mean of observations).

in the scattering spectral dependence as a function of altitude were observed. Two different aerosol plumes characterized by a significant spectral dependence (typically of submicronic polluted, smoke or fine marine aerosols) are observed around 1000 and $2000-2500 \mathrm{~m}$. Above $3000 \mathrm{~m}$, the spectral dependence is clearly reduced, corresponding to air masses with high mineral dust concentrations. For this upper aerosol layer, the scattering coefficient increases up to $60 \mathrm{M} \mathrm{m}^{-1}$. The analysis of the extinction (at $530 \mathrm{~nm}$ ) vertical profiles obtained from the CAPS system (Table 3) reveals an excellent agreement with nephelometer data showing the peaks of extinction at similar altitudes (see Denjean et al., 2015), with maxima ( $\sim 90 \mathrm{M} \mathrm{m}^{-1}$ ) logically observed within the dust plumes (4000-5000 m). Number concentrations, as well as volume size distributions, highlight the significant atmospheric loading by particles with diameter higher than $1 \mu \mathrm{m}$ above $3000 \mathrm{~m}$ (maxima of $5000 \mathrm{H} \mathrm{cm}^{-3}$ ). For this atmospheric layer, the volume size distribution is characterized by a coarse mode, around $6-8 \mu \mathrm{m}$. As previously mentioned, vertical profiles of optical properties in terms of $\mathrm{AE}$, SSA, asymmetry parameters as well as their spectral dependence are presented and discussed in details by Denjean et al. (2015) and Nicolas et al. (2016). The airborne SW and LW radiation measurements and the comparison with radiative transfer model simulations at Lampedusa are presented by Meloni et al. (2016).

\subsection{Aerosol vertical structure}

\subsubsection{Lidar surface observations}

Although deeply analyzed in other dedicated papers, some examples of the aerosol vertical profiles are presented here. First and over the Minorca station, surface lidar observations in Fig. 21a were obtained during 16 and 17 June, which corresponds to the first event of transported mineral dust over the western basin. They show a dust aerosol layer located between 1.5 and $5 \mathrm{~km}$, with a maximum of aerosol extinction (at $355 \mathrm{~nm}$ ) around $0.10 \mathrm{~km}^{-1}$ on 16 June between 12:00 and 14:00 local time (LT). Comparisons of retrieved AOD with the lidar system is shown to be very consistent with sun-photometer observations for these 2 days (Fig. 21a, top), with moderate AOD (at $355 \mathrm{~nm}$ ) ranging between 0.2 and 0.4 at maximum. During 17 June, the dust layer is less intense and the aerosol extinction above $1.5 \mathrm{~km}$ decreases. After 14:00 LT, Fig. 21a clearly shows that most of the contribution to AOD is due to the MBL over the Minorca station. At Ersa (Fig. 21b), the dust event reached the northern tip of Corsica on 19 June. A deep depolarizing aerosol layer was observed at altitudes between 3 and $6 \mathrm{~km}$. In the night of 20 June, the particulate depolarization ratio is close to $18 \%$ and the lidar ratio within the dust layer was estimated at $46 \mathrm{sr}$. The extinction coefficient remains moderate within the dust layer $\sim 0.05 \mathrm{~km}^{-1}$ (Fig. 21b) between 4 and $6 \mathrm{~km}$. It should be noted that a complete analysis of lidar observations series obtained over the cape Corsica site is reported in Léon et 


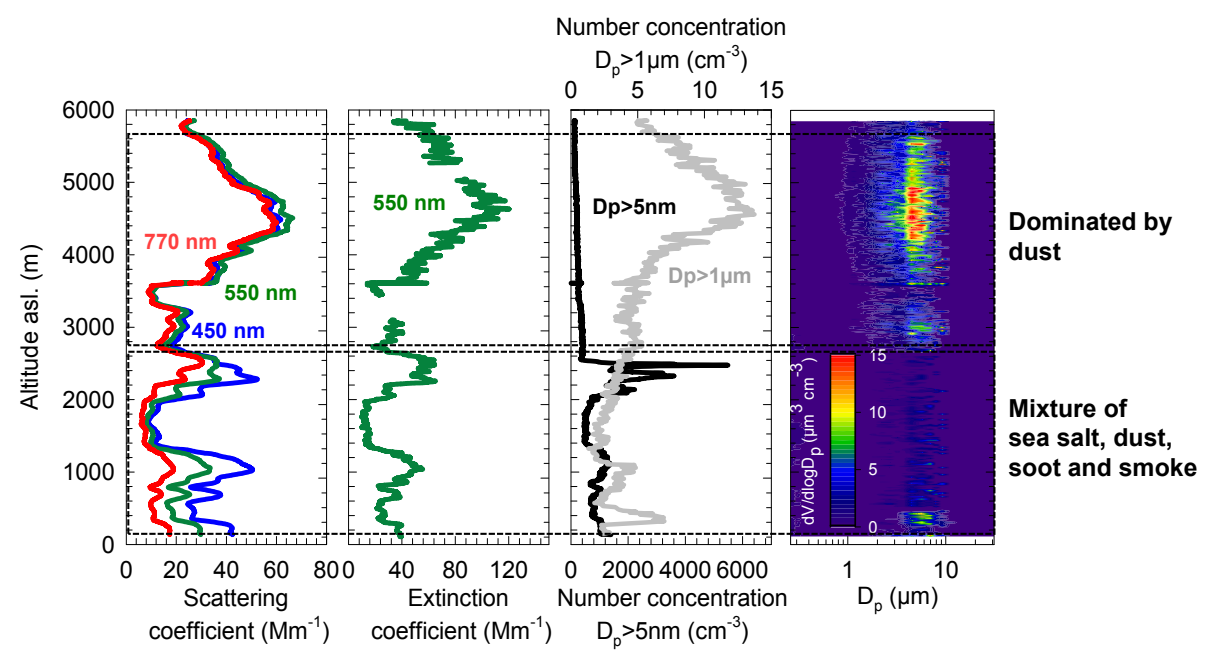

Figure 21. Optical (scattering and extinction coefficients) and physical (number concentration and volume size distribution) aerosol properties estimated along the vertical onboard the ATR-42 aircraft for the flights 35-36 on 22 June over the Lampedusa station.
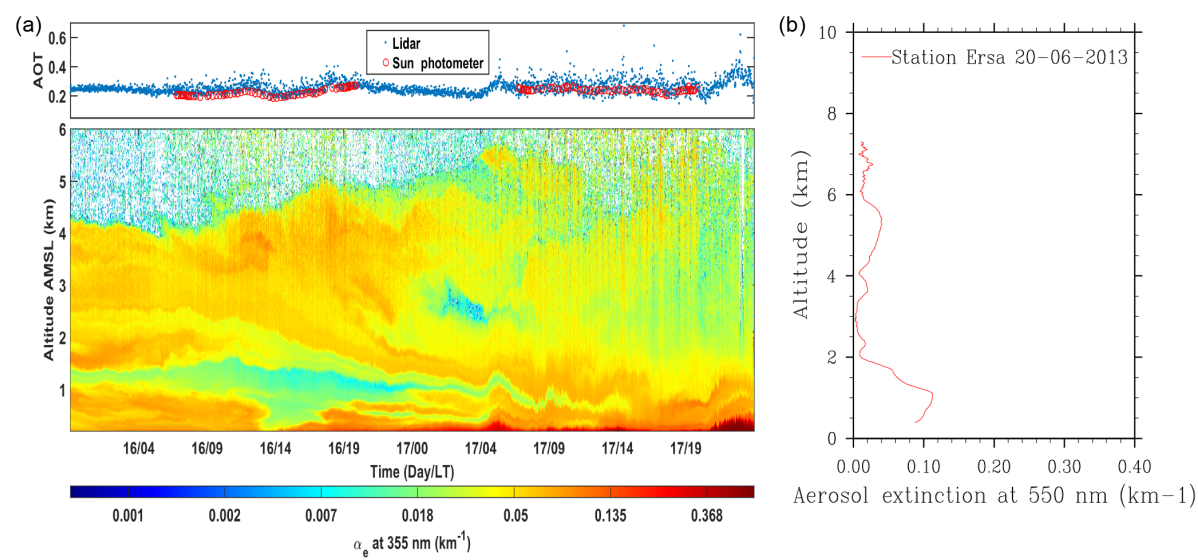

Figure 22. Minorca (a) and Ersa (b) lidar observations obtained during the dust plume of 16 to 17 June transported over the western Mediterranean basin.

al. (2015). The dust event vertical distribution is further analyzed by means of the EARLINET lidar stations in Sicard et al. (2015a) and by means of the EARLINET and ChArMEx lidar stations in Barragan et al. (2016).

In addition to Minorca and Ersa, two lidars were also operated at Lampedusa during the SOP-1a and provided vertical profiles of aerosol backscattering and depolarization. The ENEA/University of Rome lidar measures the aerosol backscattering at 532 and $1064 \mathrm{~nm}$, plus the depolarization at $532 \mathrm{~nm}$. This system was operated throughout the campaign, although not continuously. The lidar data retrieval is described by Di Iorio et al. (2009), and uses sun-photometer AOD observations to constrain the determination of the aerosol backscattering profile. Figure 23a shows the evolution of the vertical profile of the aerosol backscattering coefficient at $1064 \mathrm{~nm}$ on 3 July 2013 at Lampedusa. At low altitudes, the air masses reaching Lampedusa originated from the north. Air masses above $2 \mathrm{~km}$ conversely came from a southwesterly direction crossing northern Algeria and Tunisia, and carried desert dust. Elevated backscattering attributed to dust was observed up to $5 \mathrm{~km}$ altitude, and a steep transition in the backscattering coefficient occurred at this altitude throughout the day. Figure $22 \mathrm{~b}$ shows the backscattering coefficient profile at 532 and $1064 \mathrm{~nm}$, and the depolarization ratio measured at 15:45 UT by the ENEA/University of Rome and the LISA lidars. Evidently, the backscattering coefficient above $2 \mathrm{~km}$ shows small wavelength dependence, and elevated values of the depolarization ratio, as expected from large irregular desert dust particles (Sassen, 1999). The influence of large particles is smaller below $2 \mathrm{~km}$, where the backscattering coefficient shows some dependency on wavelength, and the depolarization ratio decreases. The significant role played by the large particles on 3 July is also confirmed by the aerosol size distribution and optical properties (i.e., 


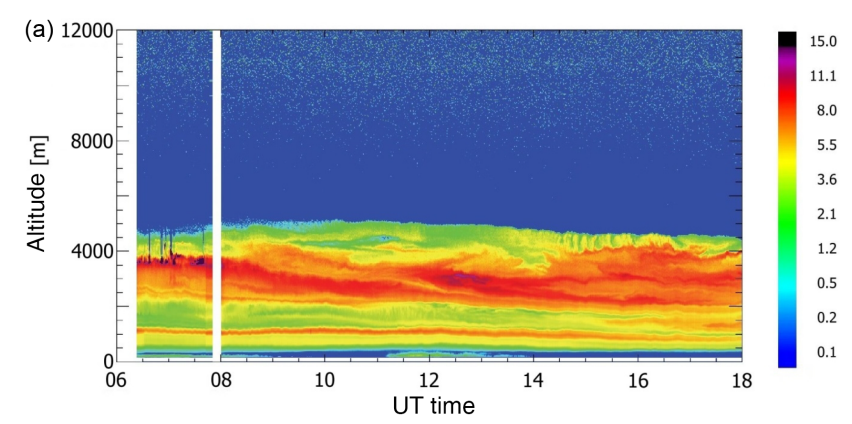

(b)

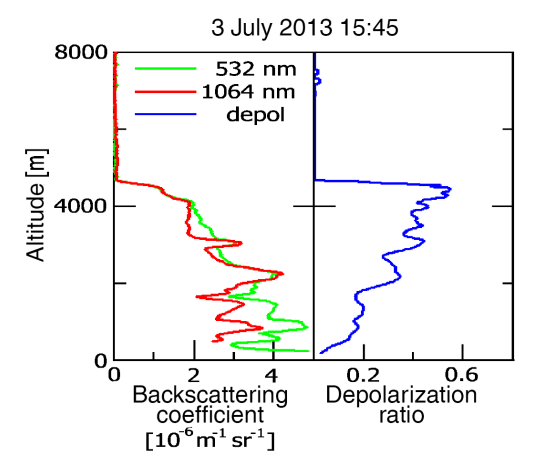

Figure 23. (a) Time evolution of the vertical profile of the aerosol backscattering coefficient at $1064 \mathrm{~nm}$ at Lampedusa on 3 July 2013. The color scale is in units of $10^{-7} \mathrm{~m}^{-1} \mathrm{sr}^{-1}$. (b) Vertical profile of aerosol backscattering coefficient at two wavelengths and of aerosol depolarization ratio at $355 \mathrm{~nm}$ measured at Lampedusa on 3 July 2013 at 15:45 UT.

values and spectral dependency of the refractive index and single scattering albedo) retrieved from the AERONET observations at Lampedusa. The average AOD (at $500 \mathrm{~nm}$ ) was 0.28 , and the $\mathrm{AE}$ (calculated between 440 and $870 \mathrm{~nm}$ ) was 0.39 , as expected for cases with a large contribution of desert dust. The retrieved columnar volume size distributions on the 2 days show that the mode with a median radius around $2 \mu \mathrm{m}$ is $2-3$ times more intense on 3 July than on 17 June.

Finally, night-time measurements at Potenza (Italy) on 21 June starting at 23:40 UT, which coincides with the arrival of the Saharan dust event over southern Italy, indicate a clear signature of Saharan dust in the tropospheric layer between 1.8 and $3.9 \mathrm{~km}$; an extinction-related $\mathrm{AE}$ value of approximately 0 is measured between roughly 2 and $3 \mathrm{~km}$ and a quite constant LR around $50 \mathrm{sr}$ at both 355 and $532 \mathrm{~nm}$ (not shown; see Sicard et al., 2015a; Barragan et al., 2016).

\subsubsection{LNG observations}

An example of LNG (Lidar Nouvelle Génération) observations onboard the F-20 aircraft is presented in Fig. 24 for 19 June that corresponds to a flight (12:46 to 13:26 UT) from Sardinia to the Gulf of Genoa. The aerosol extinction (in $\mathrm{km}^{-1}$ and at $532 \mathrm{~nm}$ ) is represented in function of latitude during this flight as well as the associated AOD with a high temporal and spatial frequency. One can observe the significant north-south gradient during this dust event with low values of AOD (around 0.1 at $532 \mathrm{~nm}$ ) for the latitude of $44^{\circ} \mathrm{N}$ and moderate-high AOD (0.40 to 0.55) for latitudes lower than $42-43^{\circ} \mathrm{N}$. In terms of vertical structure, this increase of AOD is due to an upper dust layer (around 5 to $6 \mathrm{~km}$ ) characterized by an aerosol extinction of about $0.1 \mathrm{~km}^{-1}$. This intense dust layer transported over most of the investigated region $\left(40.5-43.5^{\circ} \mathrm{N}\right)$ is associated with a second more diluted aerosol layer observed between 3 and $4 \mathrm{~km}$ with LNG. Another interesting aspect is the variability of aerosol extinction detected in the marine boundary layer showing large differences throughout the F-20 transect. The aerosol extinction is found to be significant around 41 to $41.5^{\circ} \mathrm{N}$, which could be due to sea-spray particles generated in southern Corsica due to the local acceleration of the wind occurring between Corsica and Sardinia (not shown). This increase of the aerosol loading in the MBL associated with dust aerosol transported to higher altitudes results in an increase of total AOD at these latitudes. Such aircraft lidar data will be useful for testing the different modeling systems used for the SOP-1a experiment and more specifically their ability to reproduce complex vertical aerosol structures over the western Mediterranean. Additional observations of the aerosol extinction vertical profile obtained over different surface-stations from the passive remote-sensing PLASMA instrument onboard the ATR-42 aircraft are presented in Torres et al. (2016).

\subsubsection{Sounding balloon observations}

Figure 25 shows an example of the vertical profile of the aerosol particle size distribution obtained on 19 June near the end of the dust episode that started on 16 June over Minorca. The daytime average AOD geographical distribution derived from MSG/SEVIRI is shown in Fig. 6. The vertical profile clearly shows the presence of the dust layer between about 2.5 and $4.5 \mathrm{~km}$ in altitude, in agreement with coincident lidar continuous observations at Minorca that show the more limited vertical extent of dust compared to previous days and the end of the episode on 19 June in this area (Chazette et al., 2015). It should be noted that sounding balloons appear to under-detect very large particles within dust layers compared to the drifting balloons. This can be due isokinetic sampling differences between sounding systems that have a vertical velocity of several $\mathrm{ms}^{-1}$ and systems drifting at a constant air density that are quasi-Lagrangian. However coincident AERONET and LOAC vertically integrated particle size distribution in the range $0.1-30 \mu \mathrm{m}$ in diameter performed on 16 and 17 June were found quite comparable. In the marine atmospheric boundary layer, the LOAC speciation index (Renard et al., 2015a) indicates hydrated particles. In the free troposphere above dust, the concentration of particles rapidly decreased by 1 order of magnitude and particles were mainly of submicronic size with sometimes a significant number of particles in the $1.1-3 \mu \mathrm{m}$ channel. 

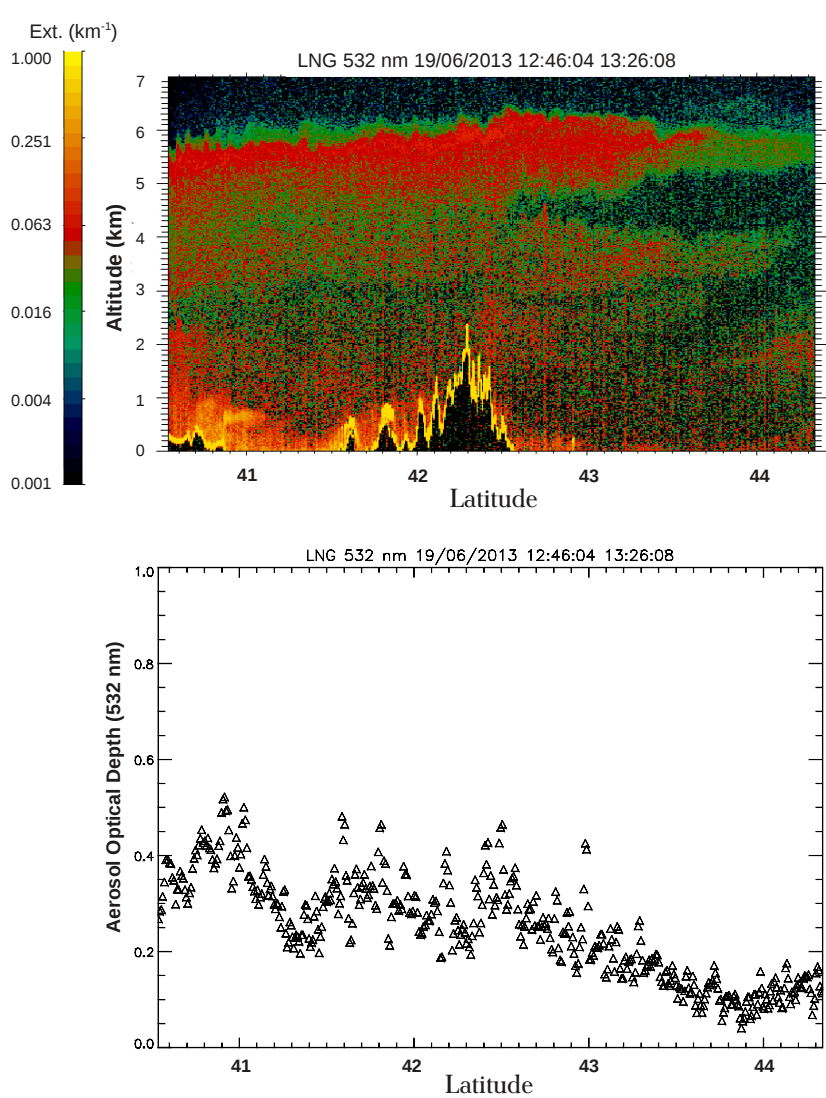

Figure 24. Observations of aerosol extinction coefficient (top, in $\mathrm{km}^{-1}$ at $532 \mathrm{~nm}$ ) and aerosol optical depth (bottom) obtained from the lidar LNG system onboard the F-20 aircraft during 19 June that corresponds to the flight (12:46 to 13:26) from Cagliari to the Gulf of Genoa.

\subsection{Local direct radiative forcing}

\subsubsection{Estimates using in situ aircraft data and radiative transfer codes over the two super-sites}

Before investigating the possible climatic effect of aerosols on the Mediterranean climate, an important preliminary step is the calculation of the direct radiative forcing (DRF) exerted by aerosols. This can be addressed by using in situ (physical-optical properties) and remote-sensing (vertical profiles) observations of aerosols as input to radiative transfer models. Simulated SW and LW radiative fluxes can be evaluated using observed radiative fluxes both at the surface and onboard the two aircraft. The combination of in situ and remote-sensing measurements provides a complete and unique data set for conducting such 1-D radiative transfer simulations. To this end, vertical profiles from the ATR-42 were combined with surface observations from the two (Ersa and Lampedusa) stations to calculate the SW DRF of different aerosol events (Nicolas et al., 2016; Meloni et al., 2016). Over the western basin and for the first period of the cam- paign (16 to 20 June), different calculations, with the GAME radiative transfer model (Dubuisson et al., 2004), of the downward and upward SW cloud-free irradiances have been performed by Nicolas et al. (2016) for six vertical profiles over Granada, Minorca and Corsica. Briefly, the methodology is based on extinction, SSA and phase function vertical profiles (and their spectral dependence), obtained from observations and Mie calculations, and associated with atmospheric thermodynamic properties. They clearly show a significant change in surface radiative fluxes with a well-known decrease (dimming effect) of downward radiations due to scattering and absorption of solar radiation by dust aerosols. Inter-comparisons between observed/simulated downward and upward clear-sky SW fluxes show a good agreement during the ascent and descent profiles. At TOA, Nicolas et al. (2016) reported a direct (instantaneous at noon) SW DRF ranged between -4 and $-33 \mathrm{~W} \mathrm{~m}^{-2}$, revealing a cooling effect due to dust particles. These simulations also indicate that the decrease in surface radiation is not completely compensated by the TOA cooling, meaning that aerosols exerted a positive atmospheric forcing due to their ability to absorb solar radiations.

Similar calculations (not shown) have been done over the Lampedusa reference-site by Meloni et al. (2016) by using a similar method based on lidar, sun-photometer, in situ surface, ATR-42 and F-20 observations and the MODTRAN 5.3 radiative transfer code. Meloni et al. (2016) estimate both the SW and the LW aerosol radiative forcing profiles and the balance between the two spectral components (SW and LW). During the descent towards Lampedusa airport on 22 June, the instantaneous $\left(12.5^{\circ}\right.$ solar zenith angle and aerosol optical depth at $500 \mathrm{~nm}$ of 0.32 ) SW cooling at the surface $\left(-44 \mathrm{~W} \mathrm{~m}^{-2}\right)$ is reduced by about $10 \%$ due to infrared emission. The dust $\mathrm{SW}$ radiative forcing at TOA is $-6 \mathrm{~W} \mathrm{~m}^{-2}$. These values are obtained using the AERONET aerosol size distribution and different aerosol refractive indices in the SW and in the LW spectral regions. The LW contribution at the surface is lower than the values reported in previous studies (di Sarra et al., 2011; Meloni et al., 2015), partially due to the different solar zenith angle and to the presence of mixed aerosol below the dust layer down to the surface.

\subsubsection{Estimates of instantaneous clear-sky SW DRF using AERONET/PHOTONS observations}

As reported previously, AERONET/PHOTONS network provides, in addition to microphysical and optical aerosol properties, an estimate of the local (instantaneous) clear-sky direct radiative forcing at any AERONET/PHOTONS location as an operational product of the network. The method of derivation is described in García et al. (2012). As mentioned above, the extremely good regional coverage of AERONET/PHOTONS sun-photometer instruments during the SOP-1a allow a complementary estimate of the local radiative (clear-sky) forcing to those derived by Meloni et 


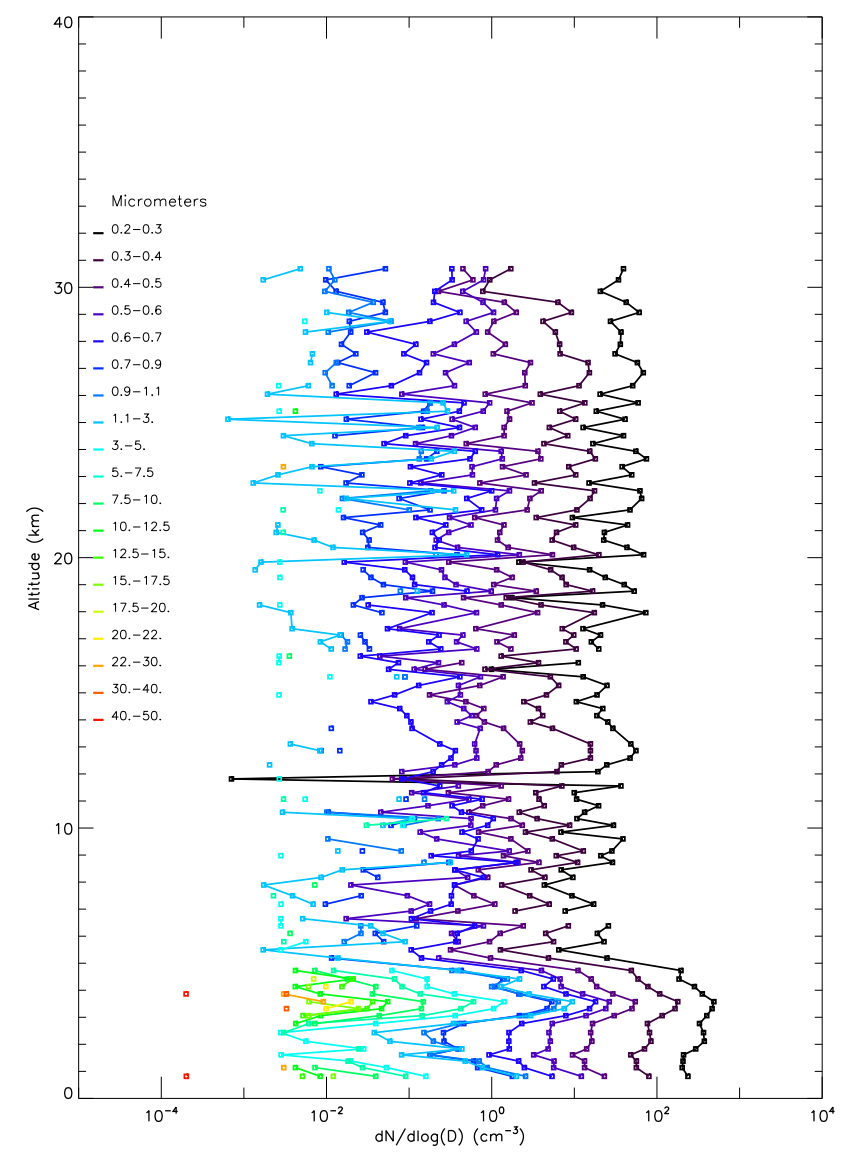

Figure 25. Particle concentrations as a function of size and altitude in the troposphere and lower stratosphere from the LOAC flight under meteorological balloon BLD9 launched from Minorca at the end of a dust event on 19 June 2013, 10:12 UT (Table 4; see the daytimeaveraged aerosol optical depth over the sea in Fig. 6).

al. (2016) and Nicolas et al. (2016). Figure 26 indicated the average of all instantaneous (clear-sky) DRFs (in $\mathrm{W} \mathrm{m}^{-2}$ ) estimated during a day for both AERONET/PHOTONS stations. Estimates are reported at the surface (bottom left), at TOA (bottom right) and within the total atmosphere (down). Averaged values of the DRF are also indicated in Fig. 26. As mentioned above, sun-photometer retrievals demonstrate a significant DRF during the SOP-1a experiment. As an example and at the surface, the mean forcing is comprised between $-15 \mathrm{Wm}^{-2}$ (Barcelona, not affected by dust transport) and $-35 \mathrm{Wm}^{-2}$ in Burjassot. Such values are consistent with independent 1-D estimates reported by Nicolas et al. (2016) and Meloni et al. (2016). AERONET/PHOTONS data also reveal a negative DRF at TOA over most of sites, meaning that aerosols exert in majority a cooling effect at TOA, with values around $\sim-6$ to $-12 \mathrm{~W} \mathrm{~m}^{-2}$. These negative values are also due to the fact that most of the AERONET/PHOTONS stations are located over islands, which are characterized by low surface albedo. Logically and due to the moderate values of aerosol absorption observed during the SOP-1a (Denjean et al., 2015), a positive atmospheric forcing is observed with mean values from +7 to $+30 \mathrm{~W} \mathrm{~m}^{-2}$ (with maxima in Burjassot), which could affect the vertical profiles of temperature and relative humidity as shown recently by Nabat et al. (2015a).

\subsubsection{Estimates using in situ radiative flux observations}

As shown by di Sarra et al. (2011), an estimate of the aerosol radiative forcing can be obtained by comparing irradiance measurements made during days characterized by different aerosol loads. In particular, the identification of a cloud-free day with low aerosol amounts is important to provide a reference for pristine conditions. During the SOP-1a, 17 June at Lampedusa displayed a very low aerosol optical depth (daily average of 0.064 at $500 \mathrm{~nm}$ ) and cloud-free conditions throughout the day, and was identified as the reference day for pristine conditions. 3 July, conversely, was one of the days characterized by the presence of desert dust, with moderate values of the AOD (0.28). As shown in Fig. 22a, dust was present above $2 \mathrm{~km}$ altitude and there were no major changes in the aerosol vertical distribution during the day, as it also appears from the limited daily variability of the AOD (daily standard deviation of the AOD at $500 \mathrm{~nm}$ of 0.015 ). Cloudfree conditions were present throughout the day.

Figure 27 displays the downward solar irradiance measured on 3 July, compared with the one measured on the pristine reference day (17 June). The irradiance measurements were corrected for the radiometer thermal offset as discussed by Di Biagio et al. (2009). The sharp narrow peak occurring on 17 June around 06:30 was related to a small isolated cloud, and these data were discarded from the analysis. The differences between the downward irradiances measured on these 2 days were calculated as a function of the solar zenith angle; these differences are due to the effect of aerosol and, to a smaller extent, column water vapor. The effect of water vapor was estimated by means of a radiative transfer model (see, e.g., di Sarra et al., 2011), and the remaining difference was integrated over $24 \mathrm{~h}$ to obtain the daily average effect, $\Delta I$, on the downward solar irradiance. The daily aerosol radiative forcing RF can be derived as

$\mathrm{RF}=\Delta I(1-A)$,

where $\Delta I$ is the difference between the two curves of Fig. 27 integrated over $24 \mathrm{~h}$, and $A$ is the surface albedo. For a surface albedo of 0.07 (di Sarra et al., 2011), the estimated surface $\mathrm{RF}$ is $-14.8 \mathrm{Wm}^{-2}$. The radiative forcing efficiency (RFE), which is the radiative forcing produced by a unit AOD, was calculated as

$\mathrm{RFE}=\mathrm{RF} /\left(\mathrm{AOD}_{2}-\mathrm{AOD}_{1}\right)$,

where $\mathrm{AOD}_{1}$ and $\mathrm{AOD}_{1}$ are the measured daily average aerosol optical depth on 17 June and 3 July, respectively. The estimated RFE is $-67.4 \mathrm{~W} \mathrm{~m}^{-2}$. Di Biagio et al. (2010), 

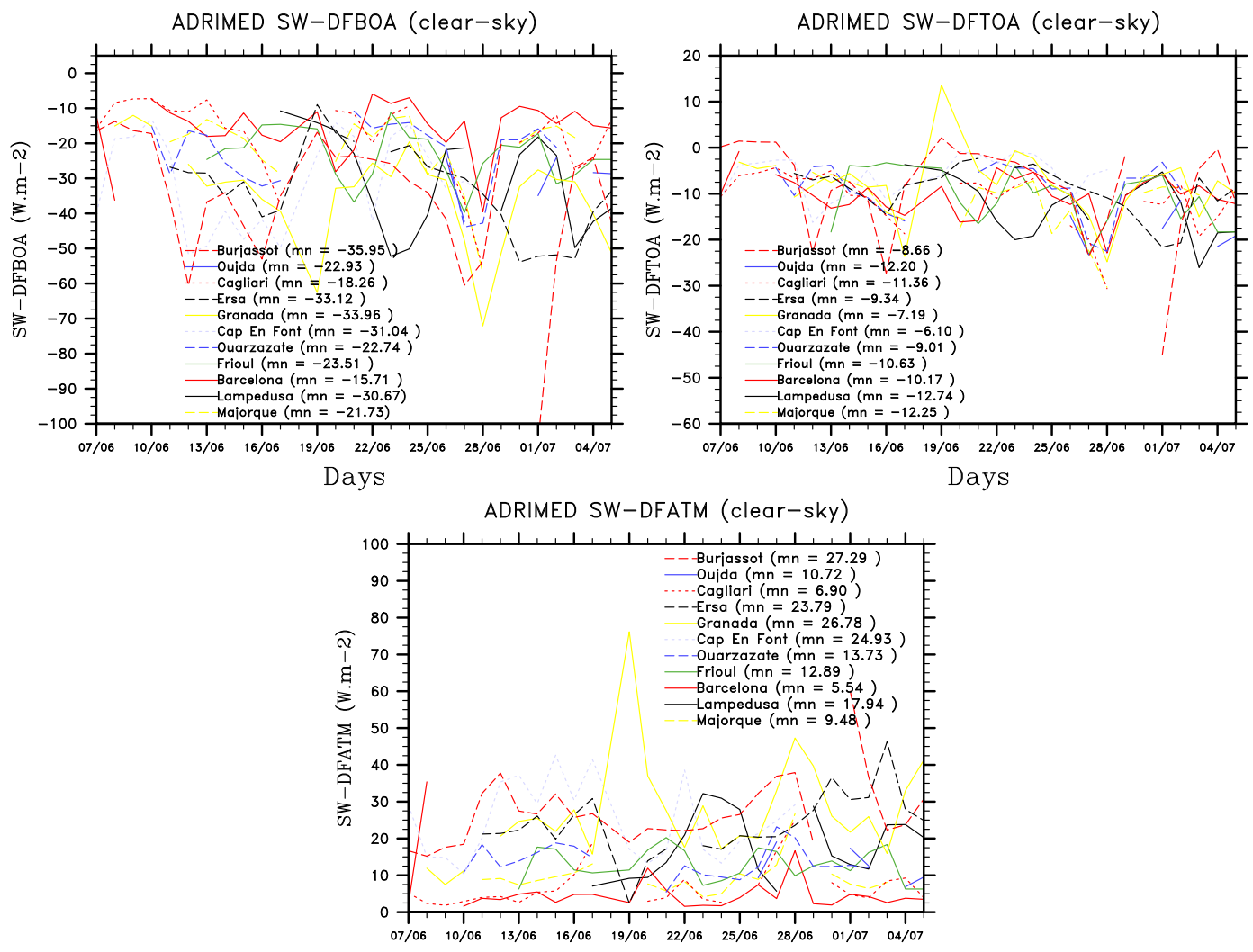

Days

Figure 26. One-dimensional (clear-sky) instantaneous (shortwave only) DRF calculations (in $\mathrm{W} \mathrm{m}^{-2}$ ) based on the AERONET/PHOTONS data set for the different stations listed in Table 2 (BOA, TOA and ATM refer to the bottom of the atmosphere, top of atmosphere and atmospheric forcings).

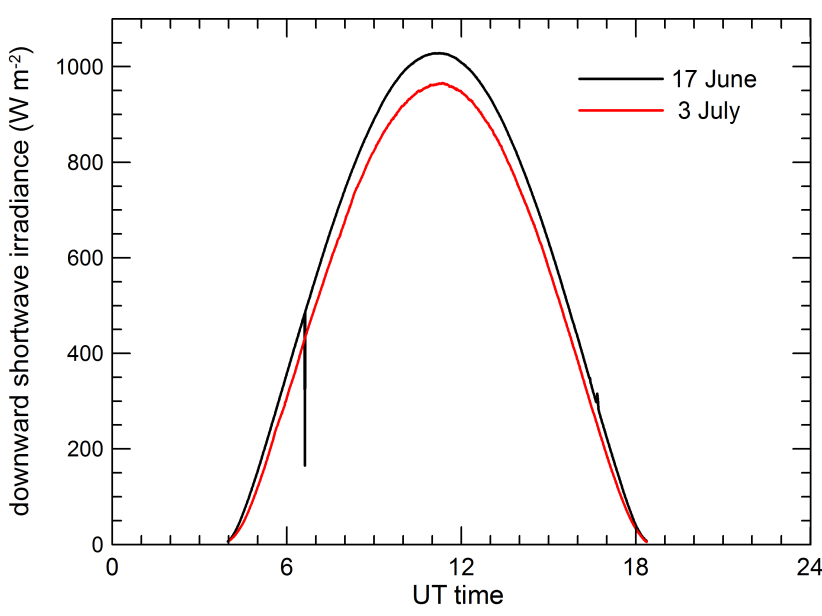

Figure 27. Time evolution of the downward solar irradiance observed at Lampedusa on 17 June and 3 July 2013.

based on a multi-year data set at Lampedusa, derived a similar value for desert dust $\left(-68.9 \mathrm{~W} \mathrm{~m}^{-2}\right)$ at the equinox; di Sarra et al. (2011), for an intense desert dust event occurring in March 2010 found values between -70 and $-85 \mathrm{~W} \mathrm{~m}^{-2}$.
For a desert dust event associated with the propagation of a gravity wave, with values of AOD similar to those of 3 July, di Sarra et al. (2013) derived an RFE equal to $-79 \mathrm{~W} \mathrm{~m}^{-2}$. Valenzuela et al. (2012) determined RFE for Saharan dust episodes over the western Mediterranean with different origins, showing values in the range from $-74 \mathrm{~W} \mathrm{~m}^{-2}$ (for air masses coming from northern Morocco) to $-65 \mathrm{~W} \mathrm{~m}^{-2}$ (for air masses coming from Algeria and Tunisia). Values of the dust RFE at the surface in the same range were obtained by Derimian et al. (2006), although they were derived in different conditions for which the influence of surface albedo should be taken into account.

The downward LW irradiance measured on 3 July was higher than on 17 June by $23 \mathrm{~W} \mathrm{~m}^{-2}$. Most of this effect is due to differences in the water vapor column amount (about $1 \mathrm{~cm}$ difference between the 2 days, with larger values on 3 July). Once the water vapor contribution was subtracted by means of radiative transfer calculations, we found a net positive effect induced by the aerosol of about $+5.5 \mathrm{~W} \mathrm{~m}^{-2}$. This is, on the daily timescale, about $35 \%$ of the SW effect. The resulting aerosol RFE in the LW spectral range is $+25.5 \mathrm{~W} \mathrm{~m}^{-2}$, in agreement with previous results by di Sarra et al. (2011), who found values between +25.9 and 

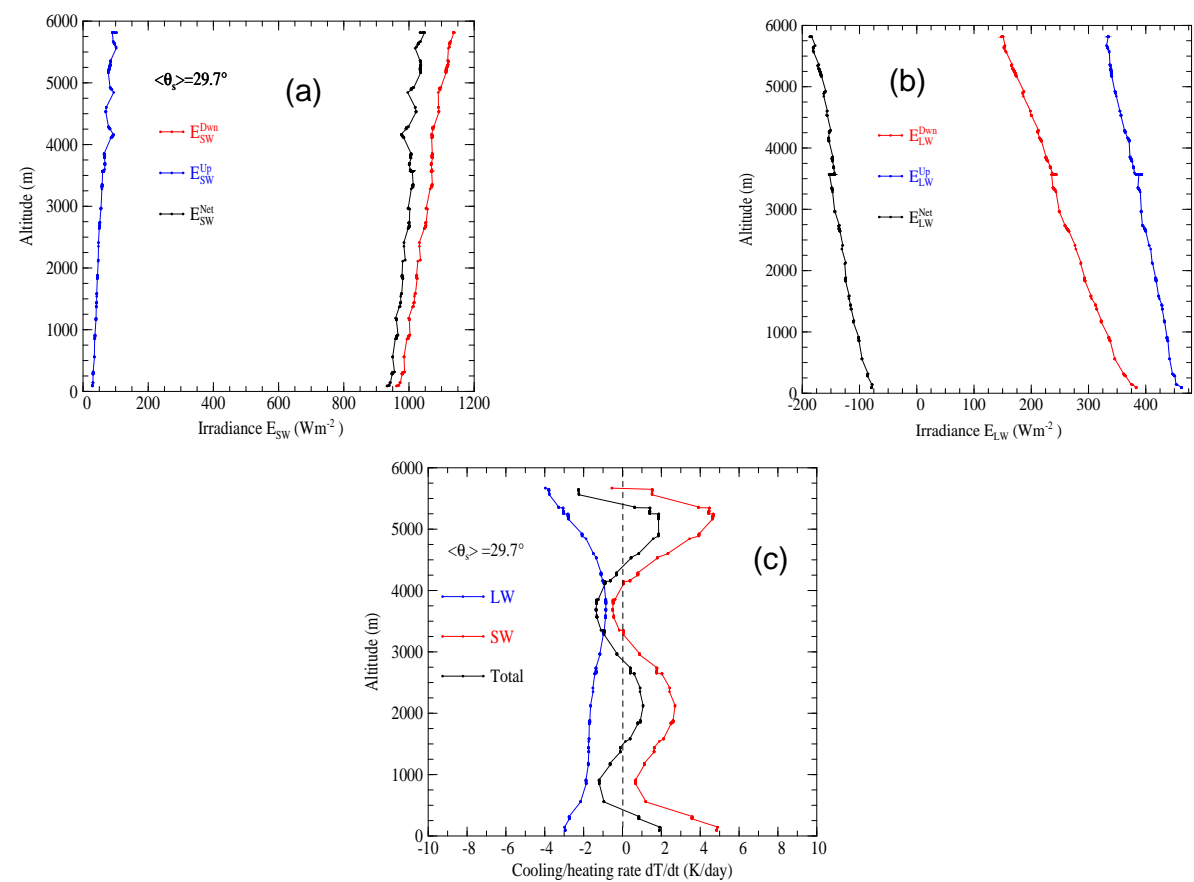

Figure 28. SW (a) and LW (b) upward and downward radiative fluxes observed over the Lampedusa station for 22 June and estimated SW and LW heating rate (c) in the two spectral regions (see Sect. 5.4.4 for details).

$+27.9 \mathrm{~W} \mathrm{~m}^{-2}$, or Antón et al. (2014), who reported RFE values around $+20 \mathrm{~W} \mathrm{~m}^{-2}$ (in reference to AOD at $675 \mathrm{~nm}$ ).

\subsubsection{Estimations of the $\mathrm{SW}$ and $\mathrm{LW}$ radiative heating rate along the vertical}

One important original aspects of this study concerns the estimates of the vertical profiles of SW and LW radiative heating rate. To our knowledge, all the referenced estimates of this important parameter, which controls for a part the semidirect radiative effect of aerosols, have been conducted using remote-sensing techniques or in situ observations of aerosol optical properties, coupled with radiative transfer modeling. Here, we propose a first estimate of the SW and LW heating rate derived directly from upward and downward (SW and LW) radiative fluxes obtained onboard the ATR-42 aircraft. Because of the nature mainly diffuse of longwave upward and downward irradiances (irradiances in thermal infrared), and of the upward shortwave irradiance (irradiance in solar domain), in first approximation, no correction due to the altitude of the aircraft will be applied to these measurements. Only shortwave downward irradiances will be corrected. Three kinds of corrections are applied:

- Correction of the aircraft attitude (unavoidable movements due to the aircraft pitch and roll)

- Correction of cosine response of the pyranometer
- Correction due to the non-horizontal position of the sensor when a leg stabilizes (i.e., determination of offsets on roll and pitch).

Let $\theta_{\mathrm{m}}$ the angle between the sun direction and the normal to the pyranometer sensor (depending on pitch, roll and aircraft heading given by the inertial navigation system), and $\theta_{\mathrm{S}}$ the solar zenith angle, the attitude correction coefficient is

$X_{d}^{n}=\frac{\cos \theta_{\mathrm{m}}}{\cos \theta_{\mathrm{s}}}$.

Finally, we obtain the global (direct plus diffuse) downward irradiance, for the solar zenith angle $\theta_{\mathrm{s}}: E_{\mathrm{SW}}^{\downarrow}\left(\theta_{\mathrm{s}}\right)=$ $\frac{E_{\mathrm{SW}}^{m \downarrow}\left(\theta_{\mathrm{m}}\right)}{\left(X_{d}^{n}\left[1-c\left(\theta_{\mathrm{s}}\right)\right]-D\right) f\left(\theta_{\mathrm{s}}\right)+D}$.

In this equation, $E_{\mathrm{SW}}^{m \downarrow}\left(\theta_{\mathrm{m}}\right)$ is the measured global irradiance, $c\left(\theta_{\mathrm{s}}\right)$ is the cosine response of the pyranometer, $D=2 \int_{0}^{1}\left[1-C\left(\theta_{\mathrm{m}}\right)\right] \mu d \mu$ and $f\left(\theta_{\mathrm{s}}\right)$ is the part of direct downward irradiance in the global (estimation obtained from radiative transfer code). Taking into account these corrections, Fig. 28a shows downward $\left(E_{\mathrm{SW}}^{\mathrm{Dwn}}\right)$, upward $\left(E_{\mathrm{SW}}^{\mathrm{Up}}\right)$, and net $\left(E_{\mathrm{SW}}^{\mathrm{Net}}\right)$ shortwave irradiances obtained from measurements performed onboard ATR-42 aircraft on 22 June between 10.35 and 11.30 UT. Irradiances are reduced to the mean solar zenith angle $\theta_{\mathrm{s}}=29.7^{\circ}$. Similarly, Fig. 28b shows corresponding measurements of downward $\left(E_{\mathrm{LW}}^{\mathrm{Dwn}}\right)$, upward $\left(E_{\mathrm{LW}}^{\mathrm{Up}}\right)$, and net $\left(E_{\mathrm{LW}}^{\mathrm{Net}}\right)$ longwave irradiances. Total 
net irradiances are then determined versus the aircraft altitude for the mean air mass factor of the considered studied flight phase. The radiative cooling/heating rate is finally derived and shown in Fig. 28c, in which the longwave (LW) and shortwave (SW) parts are distinguished.

Concerning the SW heating rate vertical profiles (Fig. 28c), one can observe the significant increase of the calculated instantaneous SW heating rate in the two different aerosol layers detected for this case (Fig. 21), especially above $4 \mathrm{~km}$, which corresponds to the maximum of extinction coefficient (up to $100 \mathrm{Mm}^{-1}$ ) due to the presence of mineral dust. For this specific layer, the values of SW heating rate peak at $4-5^{\circ} \mathrm{K}$ per day for a solar angle of $29.7^{\circ}$. We can also observe a similar tendency in the second aerosol layer, located between 1.5 and $3 \mathrm{~km}$ (see Fig. 21). Concerning the $\mathrm{LW}$ heating rate, Fig. $28 \mathrm{c}$ indicates instantaneous values ranging between -2 and $-4^{\circ} \mathrm{K}$ per day, which is also consistent with the well-known cooling effect of mineral dust in the longwave spectrum (Mallet et al., 2006; Zhu et al., 2007). As shown in Fig. 28c, the net heating rate is dominated by the SW heating (the maximum LW cooling is less than $60 \%$ of the SW heating), which leads to net SW radiative heating ranging between +0.5 and $+2 \mathrm{~K}$ per day inside the dust layer above the MBL. Such unique and original database of SW and LW radiative heating obtained over the western Mediterranean should be now used to evaluate the ability of the different models involved in the ChArMEx/ADRIMED project (see the following Sect. 6) to simulate this important radiative property for the different identified dust cases.

\section{Overview of modeling activities}

Several models are used to analyze the SOP-1a period: the meso-scale meteorological COSMO-MUSCAT model, the chemistry transport model (CTM) CHIMERE model, and two regional climate (RegCM and CNRM-RCSM) models. These models differ in terms of horizontal and vertical resolutions, physical parameterizations, aerosolchemical schemes and are able to deliver complementary information to address key scientific questions of the ChArMEx/ADRIMED experiment. Their main characteristics are summarized in Table 7.

\subsection{COSMO-MUSCAT model}

The COSMO-MUSCAT (Wolke et al., 2012) parallelized multi-scale regional model system consists of the COSMO (Consortium for Small-scale Modelling) non-hydrostatic atmosphere model that is on-line coupled to the MUSCAT (MUltiScale Chemistry Aerosol Transport Model) 3-D chemistry tracer transport model. The atmospheric dust cycle consisting of the emission, transport and deposition of dust particles is simulated within MUSCAT using meteorological and hydrological fields from COSMO. Dust emission is calculated using the emission scheme by Tegen et al. (2002) and depends on local surface wind friction velocities, surface roughness length, soil texture and soil moisture. Calculated dust emission fluxes depend on particle diameter for individual size classes that are assumed to be log-normally distributed. Following Marticorena and Bergametti (1995), dust emission is considered as threshold function of local friction velocities and thus initial dust emission is computed as a function of soil particle size distribution. Dust emission is limited to regions where active dust sources have been identified during 2006-2009 from MSG SEVIRI observations (Schepanski et al., 2007). The advection of dust particles is described by a third-order upstream scheme; dust particles are transported as a passive tracer in five independent size classes with limiting radius at $0.1,0.3,0.9,2.6,8$, and $24 \mu \mathrm{m}$. The removal of dust particles from the atmosphere is described by dry and wet deposition taking particle size, particle density, and atmospheric conditions into account. Here, the simulations of the atmospheric dust cycle are performed at a $28 \mathrm{~km}$ horizontal grid and 40 vertical layers covering northern African dust sources, the eastern North Atlantic, the Mediterranean basin and Europe.

\subsection{The CHIMERE chemistry transport model}

CHIMERE is a chemistry transport model able to simulate concentrations fields of gaseous and aerosol species at a regional scale. The model is off-line and thus needs precalculated meteorological fields to run. In this study, we used the version fully described in Menut et al. (2013), forced by the WRF meso-scale model. The horizontal domain is the same as the one of WRF, and, for the vertical grid, the 28 vertical levels of WRF are projected on the 20 levels of the CHIMERE mesh. The gaseous species are calculated using the MELCHIOR 2 scheme and the aerosols using the scheme developed by Bessagnet et al. (2004). This module takes into account species such as sulfate, nitrate, ammonium, primary organic (OC) and black carbon (BC), secondary organic aerosols (SOA), sea spray, mineral dust, and water. These aerosols are represented using ten bins, from $40 \mathrm{~nm}$ to $20 \mu \mathrm{m}$, in diameter. The life cycle of these aerosols is completely represented with nucleation of sulfuric acid, coagulation, adsorption/desorption, wet and dry deposition and scavenging. This scavenging is both represented by coagulation with cloud droplets and precipitation. The formation of SOA is also taken into account. The anthropogenic emissions are estimated using the same methodology as the one described in Menut et al. (2013) but with the HTAP masses as input data. These masses were prepared by the EDGAR Team, using inventories based on MICS-Asia, EPA-US/Canada and TNO databases (http://edgar.jrc.ec.europa.eu/htap_v2). Biogenic emissions are calculated using the MEGAN emissions scheme (Guenther et al., 2006), which provides fluxes of isoprene, terpene and pinenes. In addition to this 2013 version, several processes were improved and added in the framework 
of this study. First, mineral dust emissions are now calculated using new soil and surface databases, as described in Menut et al. (2013). Second, chemical species emissions fluxes produced by vegetation fires are estimated using the new highresolution fire model presented in Turquety et al. (2014). Finally, the photolysis rates are explicitly calculated using the FastJ radiation module (Mailler et al., 2015).

\subsection{The RegCM regional climate model}

The RegCM system is a community model designed for use by a varied community composed of scientists in industrialized countries as well as developing nations. It is supported through the Regional Climate Network, or RegCNET, a widespread network of scientists coordinated by the Earth System Physics section of the Abdus Salam International Centre for the Theoretical Physics (ICTP, Giorgi et al., 2012). RegCM is a hydrostatic, compressible, sigma-p vertical coordinate model. As a limited area model, RegCM requires initial and boundary conditions that can be provided both by NCEP or ECMWF analyses. The horizontal resolution used need to be higher than $10 \mathrm{~km}$, due to the hydrostatic dynamic core of the model, associated with 23 vertical levels. A simplified aerosol scheme specifically designed for application to long-term climate simulations has been incrementally developed within the RegCM system. Solmon et al. $(2006,2008)$ first implemented a first-generation aerosol model including sulfates, organic carbon, and black carbon. Zakey et al. (2006) then added a four-bin desert dust module, and Zakey et al. (2008) implemented a two-bin sea-spray scheme. In RegCM, the dust emission scheme accounts for sub-grid emissions by different types of soil. The dust emission size distribution can now also be treated according to Kok (2011). When all aerosols are simulated, 12 additional prognostic equations are solved in RegCM, including transport by resolvable scale winds, turbulence and deep convection, sources, and wet and dry removal processes. In RegCM, the natural/anthropogenic aerosols are radiatively interactive both in the solar and infrared regions and so are able to feedback on the meteorological fields.

\subsection{The CNRM-RCSM regional climate model}

The fully coupled RCSM (Regional Climate System Model), which is developed at CNRM, has also been used within the ChArMEx/ADRIMED project. This model includes the ALADIN-Climate (Déqué and Somot, 2008) regional climate atmospheric model, the NEMOMED8 (Beuvier et al., 2010) regional ocean model and the ISBA (Noilhan and Mahfouf, 1996) land-surface model. We used here the version described in Nabat et al. (2015b) with a $50 \mathrm{~km}$ horizontal resolution. ALADIN-Climate includes the Fouquart and Morcrette radiation scheme based on the ECMWF model incorporating effects of greenhouse gases as well as direct effects of aerosols. The NEMOMED8 ocean model is the regional eddy-permitting version of the NEMOV2.3 ocean model that covers the Mediterranean Sea. Concerning the aerosol phase, the ALADIN-Climate model incorporates a radiative scheme to take into account the direct and semidirect effects of five aerosol types (sea spray, desert dust, sulfates, black and organic carbon aerosols) through either AOD climatologies or a prognostic aerosol scheme (Nabat et al., 2013, 2015b). On the one hand, Nabat et al. (2013) have proposed a new AOD monthly climatology over the period 2003-2009, based on a combination of satellite-derived and model-simulated products. The objective is to have the best estimation of the atmospheric aerosol content for these five most relevant aerosol species. On the other hand, a prognostic aerosol scheme has been recently implemented in ALADIN-Climate, and has shown its ability to reproduce the main patterns of the aerosol variability over the Mediterranean (Nabat et al., 2015b).

Using CNRM-RCSM with the new AOD monthly climatology over the period 2003-2009 (Nabat et al., 2013), Nabat et al. (2015a) have notably highlighted the response of the Mediterranean sea surface temperature (SST) to the aerosol direct and semi-direct radiative forcing. Figure 29a presents the annual average difference in SST over the period 20032009 between a simulation ensemble including aerosols and a second one without any aerosol. Aerosols are found to induce an average decrease in SST by $0.5^{\circ} \mathrm{C}$, because of the scattering and absorption of incident radiation. As a consequence, the latent heat loss is also reduced by aerosols (Fig. 29b), as well as precipitation (Fig. 29c). This result also underlines the importance of taking into account the oceanatmosphere coupling in regional aerosol-climate studies over the Mediterranean.

\subsection{SOP-1a multi-model aerosol simulations}

\subsubsection{Aerosol optical depth}

Figure 30 reports the AOD (in the visible range) simulated for the SOP-1a period and for the COSMO-M $(550 \mathrm{~nm})$, RegCM (between 440 and $670 \mathrm{~nm}$ ), CNRM-RCSM (550 nm) and CHIMERE $(500 \mathrm{~nm})$ models. Except for the CTMCHIMERE model, which includes all the secondary species (SOA and inorganic), the others have different aerosol schemes and take into account both natural (COSMO-M) or natural plus a part of anthropogenic aerosols as described in Table 7. The configurations used for each models are listed in Table 7. One can observe the large variability of AOD simulated by models over the Mediterranean region, with highest values clearly simulated by the COSMO-M (AOD 11.5 in the visible wavelengths) over the northern African region. The CHIMERE model indicates two different regions where AOD peaks around 1, over Algeria-Tunisia and southern Morocco. For COSMO-M and CHIMERE, no intense dust AOD is simulated over northeastern Africa (Libya and Egypt), and values are below 0.25 , contrary to RegCM and 

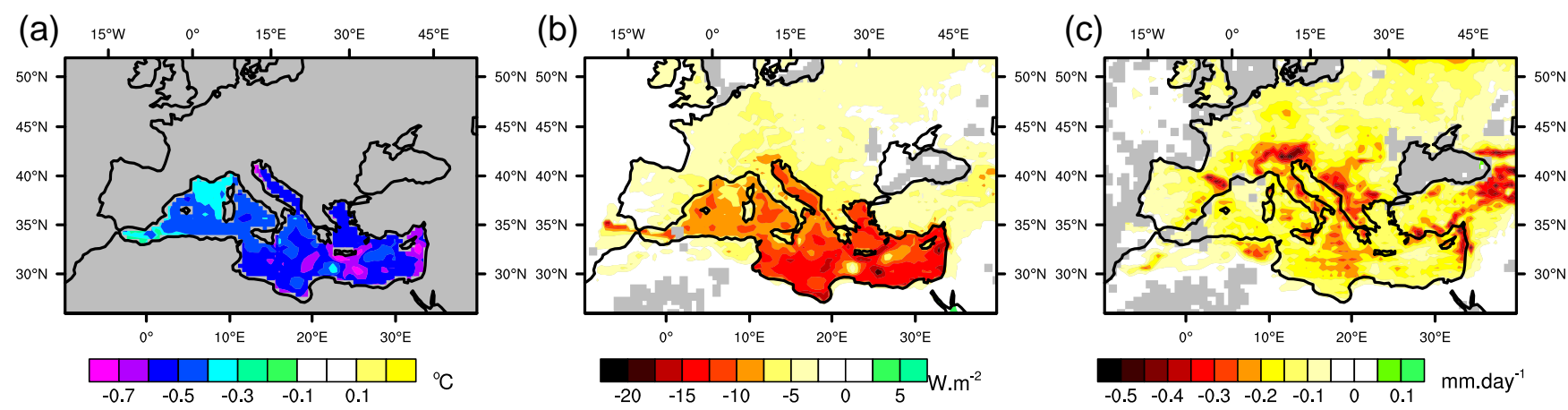

Figure 29. Annual average difference in (a) sea surface temperature (SST), latent heat loss (b) and precipitation (c) over the period 20032009 between a simulation ensemble including aerosols and a second one without any aerosol.
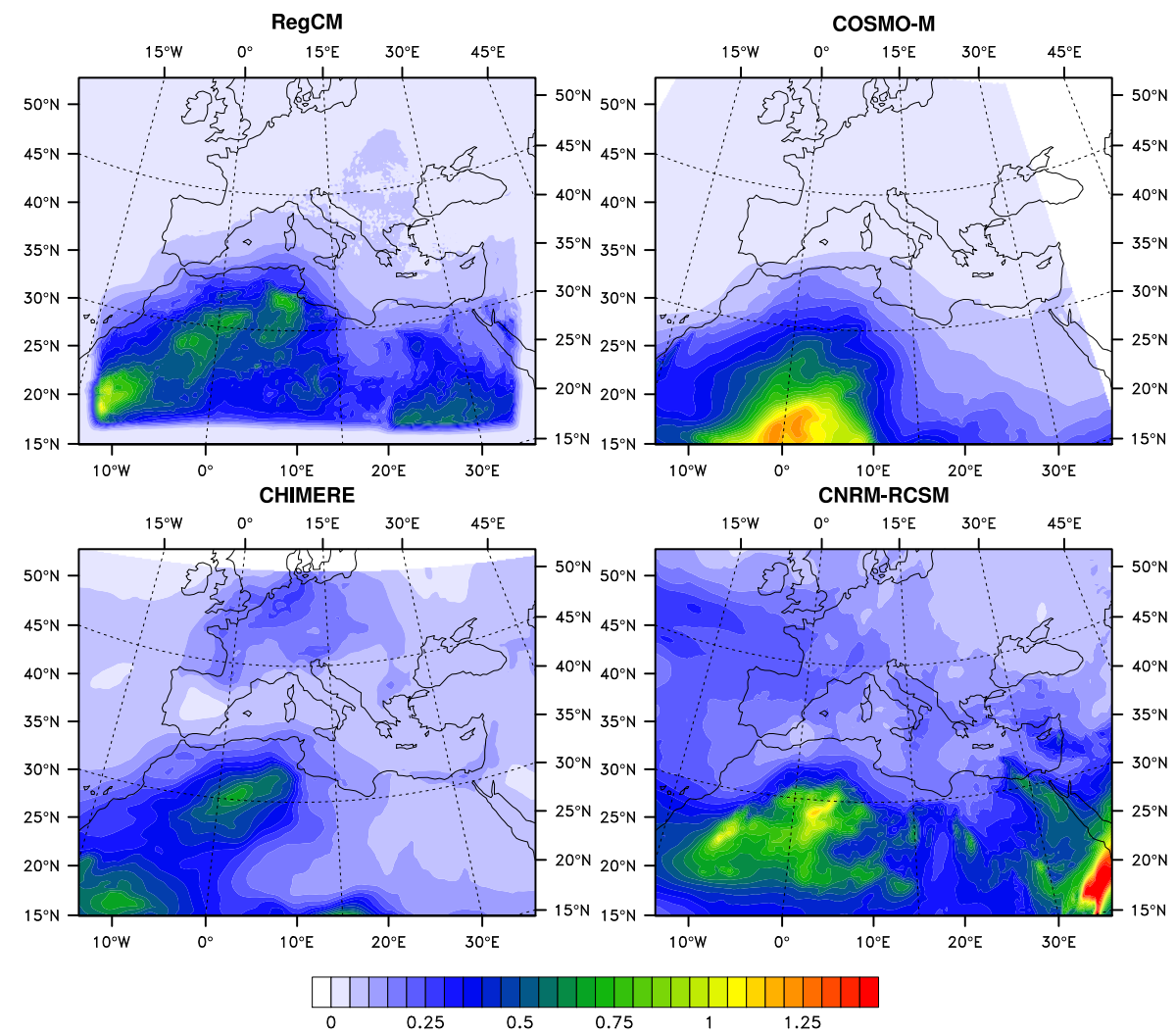

Figure 30. AOD averaged for the 15 to 25 June 2013 period from the models RegCM, COSMO-MUSCAT, CHIMERE and CNRM-RCSM. Details about the model configurations are provided in Table 7.

CNRM-RCSM that simulate moderate AOD over this region, with more intense peaks $(\sim 0.7$ for CNRM-RCSM simulations). Some identified regions with important AOD over Tunisia, Algeria, and southern Morocco are well captured by all models, except COSMO-M, which shows more intense AOD south of Algeria. It should be noted that this regional pattern of AOD is found to be consistent with MODIS observations as shown by Menut et al. (2015) for the CHIMERE model. Averaged over the SOP-1a period, all models simulate low to moderate AOD over the EURO-Mediterranean region, which is consistent with AERONET/PHOTONS observations (Fig. 14). Once again and as noted by Menut et al. (2015), this modeling exercise clearly shows that the summer of 2013 was not characterized by intense dust plumes or intense anthropogenic or forest fire emissions. However, modeling results indicate regular dust intrusions during the SOP-1a characterized by moderate atmospheric loads. Over Europe, the CHIMERE CTM obviously simulates anthropogenic aerosol AOD (AOD 0.3), especially over Benelux and the Po Valley that are not simulated by 

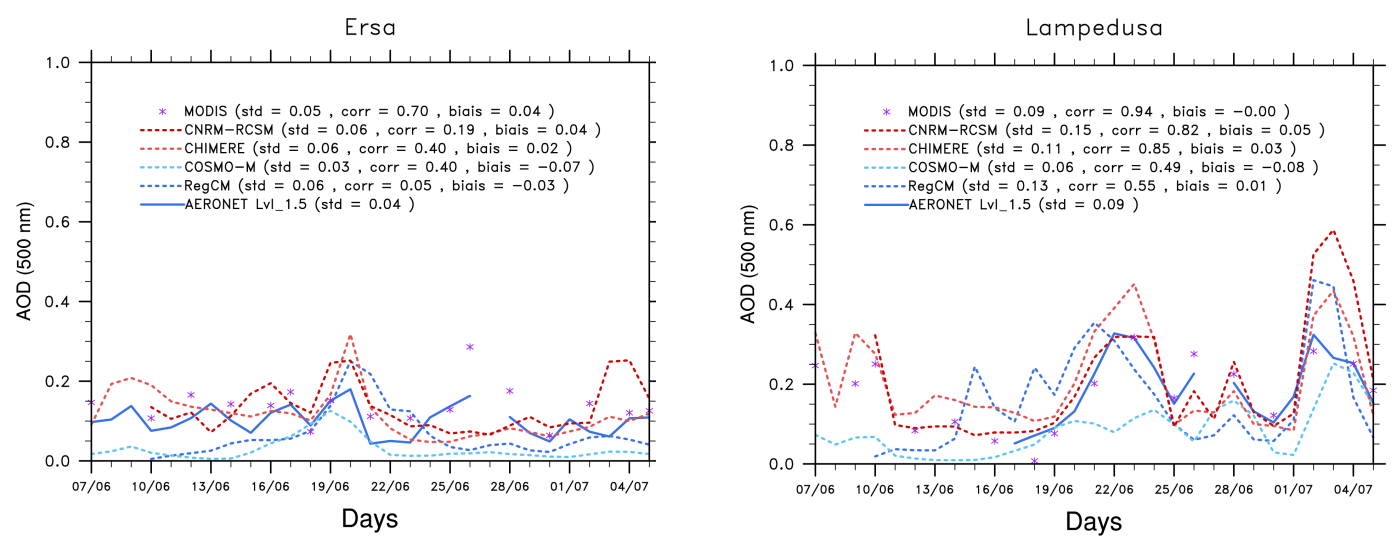

Figure 31. Time series of AOD comparisons between AERONET/PHOTONS observations and COSMO-MUSCAT, CHIMERE, CNRMRCSM and RegCM model outputs over the two stations of Ersa and Lampedusa. The MODIS retrievals are also indicated.

the two other regional models. Indeed, CNRM-RCSM simulations reveal a more diffuse AOD about 0.2 over Europe with maximum over Western France certainly due to the advection of primary marine particles generated over the Atlantic Ocean. RegCM simulations indicate a plume of anthropogenic aerosols over the Balkan region mainly due to secondary inorganic species. As RegCM does not use the spectral nudging technique in this simulation and are only forced at the boundaries during the period of simulation, some biases in meteorological fields could appear (as for the precipitation location and intensity), which need to be evaluated. Finally and in addition to analysis of the AOD regional pattern, a specific comparison with in situ observations and remotesensing (AERONET/PHOTONS and satellite) data has been made for the CTM-CHIMERE model (Menut et al., 2015) and is planned in accompanied studies for the COSMO-M, RegCM and CNRM-RCSM models, associated with an intercomparison exercise for evaluating the dust emissions, vertical distribution, size distribution and dry/wet deposition using all data collected in the framework of the SOP-1a.

In parallel to time-averaged AOD simulated at the regional scale, we report comparisons of simulated AOD with AERONET/PHOTONS data for the two reference stations (Lampedusa and Ersa). As reported in Table 7, it should be reminded here that all models did not take into account aerosol species in a similar way. As an example, COSMOMUSCAT includes mineral dust only in this simulation, while CNRM-RCSM and the RegCM model include natural (sea spray and dust) and sulfates as well as secondary ammonium and nitrate particles (treated as bulk aerosols), but for RegCM only. The most complete regional model is the CTM-CHIMERE, which takes into account natural and all anthropogenic particles (including secondary organics and inorganic) resolved in size by using a number of bins (Menut et al., 2013) higher than used in RegCM, CNRM-RCSM or COSMO-MUSCAT (number of dust bins between 3 and 4 bins) models. Figure 31 reports the time evolution of simu- lated and observed AOD at $550 \mathrm{~nm}$ for the two sites (Ersa and Lampedusa) during the SOP-1a. Time correlation, as well as bias, is calculated after removing AERONET/PHOTONS data for 27 June, strongly affected by smoke aerosols transported from North America biomass burning sources that are not included in the different domains. Figure 31 indicates that all models are able to simulate AOD in the range of magnitude of observations. For the dusty Lampedusa site, CNRM-RCSM and CHIMERE reveal high temporal correlations ( 0.82 and 0.85 , respectively), with standard deviations close to AERONET/PHOTONS data, especially for CHIMERE. For this station, COSMO-M and RegCM display moderate temporal correlation $(0.55$ and 0.49 , respectively) compared to CNRM-RCSM and CHIMERE. As already mentioned, one reason for the lowest time correlation for these models is related to the fact that they are only forced at the boundaries, and the synoptic conditions inside the domain can be derived during the simulation. This effect is limited for CNRM-RCSM that used the spectral nudging technique and for CHIMERE forced by WRF meteorological field (Menut et al., 2015). For each models, biases are shown to be low, both positive (for CNRM-RCSM and CHIMERE) and negative (for COSMO-M and RegCM).

For the Ersa station, less influenced by long-range transport of mineral dust during this period, temporal correlations are lowest and found to be moderate (0.40) for CHIMERE and COSMO-M and low for RegCM and CNRM-RCSM. In terms of bias, values are positive and low (0.02 to 0.04) for all models, except for COSMO-M ( -0.07$)$, which does not include anthropogenic aerosols or sea spray in the present simulation (Table 7). For each model, calculated standard deviations are in the same range of magnitude but slightly higher than observations, especially for RegCM (bias of 0.08) that simulated a large AOD for the 19-20 June period. By comparison with the values obtained in Lampedusa, these low correlations at Ersa reveal the limitations of these models in terms of horizontal resolution with respect to the 

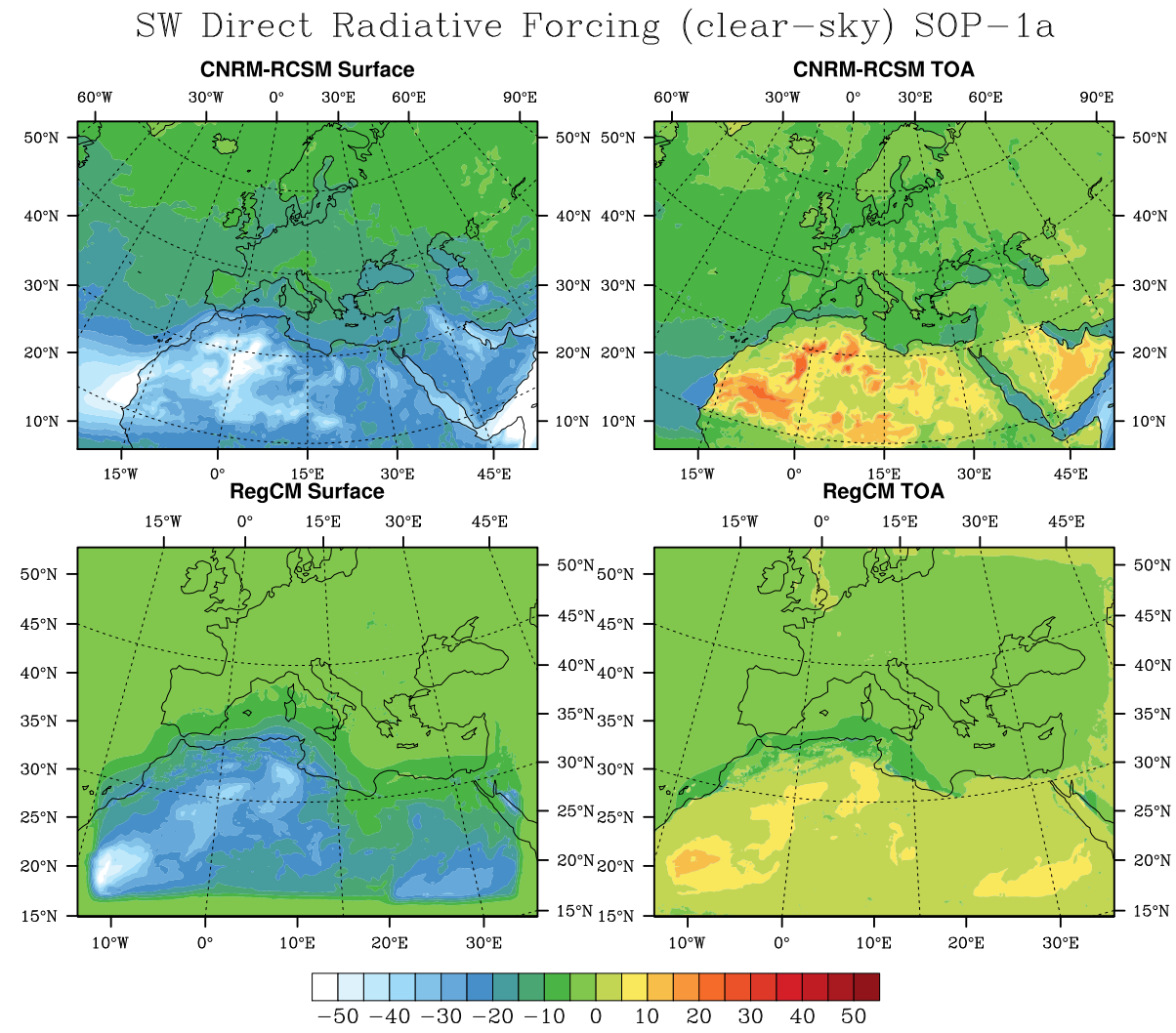

Figure 32. Averaged surface and TOA SW DRF simulated in clear-sky conditions and over the SOP-1a period by the CNRM-RCSM and RegCM models.

representativeness of the site. Lampedusa being isolated in the middle of the Mediterranean and under the main pathways of African mineral dust, AOD is mostly related to longrange transport. On the other hand, the site of Ersa in Corsica may under several types of aerosol contributions (anthropogenic, biogenic) be more intense and more spatially variable than in Lampedusa. Ersa being closer to large industrial areas, the models with a horizontal resolution of tens of kilometers are probably not highly enough resolved to catch small-scale aerosol plumes from the continent.

\subsubsection{Regional SW 3-D direct radiative forcing}

The SW (clear-sky) DRF, averaged for the SOP-1a period, has been estimated from the RegCM and CNRM-RCSM models, both at the surface and TOA, as shown in Fig. 32 . For this discussion, we only consider these two models as they estimate the clear-sky SW DRF by taking into account natural and anthropogenic aerosols, contrary to the COSMOMUSCAT model in this study. At the surface first, one can observe the large regional dimming due to anthropogenic (especially over Europe) and natural (northern Africa and Mediterranean) particles over the Euro-Mediterranean. Concerning the northern African region, both models simulate large surface forcing $\sim-20 \mathrm{~W} \mathrm{~m}^{-2}$ (with local maxima of
$-50 \mathrm{~W} \mathrm{~m}^{-2}$ associated with higher AOD). CNRM-RCSM is shown to simulate higher surface radiative forcing for the whole domain, especially over Algeria. Although such RCM climate models are not designed to simulate finely the size distribution and the chemical composition of aerosols as an A-Q (Air-Quality) system (Menut et al., 2013), a first estimate of the radiative effect of polluted particles over Europe is provided. Figure 32 displays a negative forcing, obviously lower than for mineral dust, of about -10 to $-15 \mathrm{~W} \mathrm{~m}^{-2}$ for RegCM, especially over the Balkans, and no significant radiative effect over the Benelux region for this period. Over the continental region, CNRM-RCSM simulated a more diffuse surface forcing with values around $-10 \mathrm{~W} \mathrm{~m}^{-2}$, including a large part of Europe (France, Benelux and eastern Europe). As shown recently by Nabat et al. (2015a), this decrease in SW radiations due to aerosols could perturb the surface continental temperature, SST and latent heat fluxes over the Mediterranean Sea and more largely on meteorological fields.

At TOA, the dipole of the direct forcing between the north and the south of the domain is well reproduced by the two RCM systems, with more intense values for CNRMRCSM. One can clearly observe positive forcing at TOA (heating) over northern Africa and negative forcing (cooling) over the Mediterranean and Europe. This represents one of 


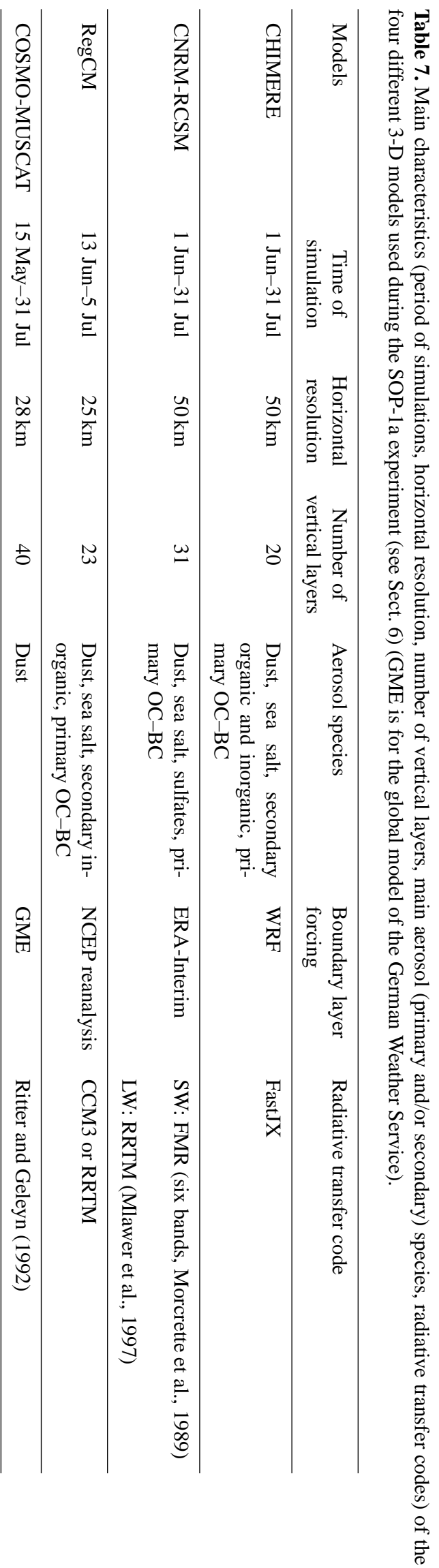

the characteristics of the Euro-Mediterranean region, with a large variability of surface albedo from the south (with higher values) to the north (low to moderate albedo). Due to this gradient in the surface albedo, moderate absorbing dust aerosols emitted over northern Africa (characterized by high surface albedo) decrease the shortwave radiations reflected at TOA, compared to a non-turbid atmosphere. When advected above low surface reflectance as marine or dense forest over Europe, dust aerosols increase the upward SW radiations at TOA, leading to a cooling effect. One can see the transition from positive to negative TOA forcing that occurs over northern Algeria and Morocco as soon as dust particles are transported over darker surfaces. This TOA radiative forcing gradient is well captured by such RCM models that use a finer resolution than GCM. Over Europe and Mediterranean, the TOA forcing is simulated to be negative for both RCM with lower values around -5 to $-10 \mathrm{Wm}^{-2}$. Such results are consistent with the study of Nicolas et al. (2016), who performed two different simulations using different surface albedo (from marine to continental), based on the ATR-42 observations above the Balearic Islands and the Granada station. The inclusion of high surface albedo $(0.27$ at $870 \mathrm{~nm})$ in the 1-D radiative transfer model compared to low sea surface albedo $(0.02$ at $870 \mathrm{~nm})$ contributes to decrease the TOA radiative effect at Granada.

The last important point to mention here concerns the fact that most SW radiation losses at the surface are not completely compensated for by fluxes reflected back to space. Hence, this gain in solar energy within dusty layers (due to moderate dust SW absorption; see Denjean et al., 2015) has been shown to result in significant feedbacks on the temperature and relative humidity profiles over the Mediterranean region, with some important implications for its climate (Nabat et al., 2015a).

\section{Conclusions}

The special observing period (SOP-1a) performed during the Mediterranean dry season (11 June to 5 July 2013) over the western and central Mediterranean basins has been described in detail, as well as the 1-D to 3-D modeling effort, involved in the ChArMEx/ADRIMED project focused on aerosol-radiation-climate interactions. Details of the in situ and remote-sensing instrumentation deployed at the different sites and the main meteorological conditions that occurred during the campaign have been provided. Some results from the in situ and remote-sensing observations, vertical profiles, 1-D and 3-D aerosol direct radiative forcing (DRF) computations have also been presented. Concerning the aerosol loading during the SOP-1a, our results indicate that numerous but moderate mineral dust plumes were observed during the campaign with main sources located in Morocco, Algeria and Tunisia, leading to AOD between 0.1 and 0.6 (at $440 \mathrm{~nm}$ ) over the western and central 
Mediterranean. Analysis of synoptic situations demonstrates unfavorable conditions to produce large concentrations of polluted smoke particles during the SOP-1a, but interesting sea-spray events have been observed.

Aerosol extinctions measured onboard the ATR-42 show local maxima reaching up to $150 \mathrm{Mm}^{-1}$ within the dust plume, associated with extinctions of about $50 \mathrm{M} \mathrm{m}^{-1}$ within the marine boundary layer (MBL), possibly due to the presence of sea-spray aerosols. By combining ATR-42 extinction, absorption and scattering measurements, complete optical closures have been made, revealing an excellent agreement in estimated optical properties. This additional information on extinction properties has allowed calculation of the dust single scattering albedo (SSA) with a high level of confidence over the western Mediterranean. Our results show a surprising moderate variability from 0.90 to 1.00 (at $530 \mathrm{~nm}$ ) for all flights studied, corroborated by AERONET/PHOTONS SSA retrievals. The SSA derived during the ChArMEx/ADRIMED project has also been compared with referenced values obtained near dust sources, showing a relatively low difference in this optical parameter at $530 \mathrm{~nm}$.

Concerning the aerosol vertical structure, active remotesensing observations, at the surface and onboard the F-20, indicate complex vertical profiles of particles with sea spray and pollution located in the MBL, and mineral dust and/or even aged North American smoke particles located above (up to $6-7 \mathrm{~km}$ in altitude). Microphysical properties of aerosols measured onboard the ATR-42 and balloon-borne observations for transported/aged mineral dust reveal particle volume size distributions with diameters greater than $10 \mu \mathrm{m}$. In most cases, a coarse mode of mineral dust particles, characterized by an effective diameter $D_{\text {eff,c }}$ ranging between 5 and $10 \mu \mathrm{m}$, has been detected within the dust layer located above the MBL. Such values are found to be larger than those referenced in dust source regions during FENNEC, SAMUM1 and AMMA, as well as measurements in the Atlantic Ocean in the Cape Verde region during SAMUM-2 and at Puerto Rico during PRIDE.

In terms of shortwave (SW) and longwave (LW) DRF, in situ surface and aircraft observations have been merged and used as inputs in different radiative transfer codes for calculating the 1-D DRF. Modeling results show significant surface (instantaneous) SW radiative forcing down to as much as $-90 \mathrm{~W} \mathrm{~m}^{-2}$ over super-sites. In parallel, AOD together with surface radiative flux observations have also been used to directly estimate the local daily surface forcing in SW (and LW) spectral regions, showing a significant effect with values of $-15 \mathrm{~W} \mathrm{~m}^{-2}\left(+5.5 \mathrm{~W} \mathrm{~m}^{-2}\right)$ over Lampedusa. Such DRFs are consistent with those previously referenced over the Mediterranean basin. In parallel, aircraft observations also provide original and new estimates of SW and LW radiative heating vertical profiles with significant values of SW heating of about $5^{\circ} \mathrm{K}$ per day within the dust layer (for a solar angle of $30^{\circ}$ ).
Associated 3-D modeling studies, using regional climate (RCM) and chemistry transport (CTM) models, indicate a relatively good agreement between simulated AOD and that determined from AERONET/PHOTONS data. Such models allow 3-D calculations of the daily SW DRF revealing a regional DRF of -10 to $-20 \mathrm{~W} \mathrm{~m}^{-2}$ (at the surface and in clear-sky conditions), when averaged over the SOP-1a period. At TOA, a significant dipole in the DRF is estimated between the north and the south of the domain, with positive (heating) over northern Africa and negative (cooling) DRF over the Mediterranean basin and Europe, reflecting changes in surface albedo associated with moderately absorbing aerosols. A first multi-year simulation (conducted for the 2003 to 2009 period) that takes into account the oceanatmosphere coupling has demonstrated that the significant aerosol radiative forcing is responsible for a decrease in sea surface temperature (on average $-0.5^{\circ} \mathrm{C}$ for the Mediterranean). In addition, the latent heat loss is shown to be weaker in the presence of aerosols, resulting in a decrease in specific humidity in the lower troposphere, and a reduction in cloud cover and precipitation.

This unprecedented data set of aerosol microphysical, chemical, optical properties and vertical profiles obtained over the western Mediterranean will now be used for evaluating regional models to reproduce such properties. In addition to classical model evaluations based generally on the AOD, new comparisons between models and in situ observations on aerosol absorbing (SSA and AAOD) properties and SW and LW heating rates, which control the semi-direct effect of aerosols, should be conducted. Comparisons will also be performed on the aerosol size distribution for investigating the ability of regional models to simulate the observed large dust particle size during the transport over the Mediterranean, which could be helpful for improving the representation of deposition in such models. In parallel, in situ observations of sea-spray particles obtained at the surface and from ATR-42 measurements will also be used to evaluate the different primary sea-spray generation schemes, in terms of concentration and size distribution. The objective is to improve the representation of microphysical and optical properties of aerosols in regional climate models that will be used in multi-year simulations to assess the impact of natural and anthropogenic aerosols on the climate in this region.

Acknowledgements. This research has received funding from the French National Research Agency (ANR) project ADRIMED (contract ANR-11-BS56-0006). This work is part of the ChArMEx project supported by ADEME, CEA, CNRS-INSU and MétéoFrance through the multidisciplinary programme MISTRALS (Mediterranean Integrated Studies aT Regional And Local Scales). The station at Ersa was partly supported by the CORSiCA project funded by the Collectivité Territoriale de Corse through the Fonds Européen de Développement Régional of the European Operational Program 2007-2013 and the Contrat de Plan Etat-Région. We acknowledge the AERONET/PHOTONS sun-photometer networks 
and the PIs of the selected stations and their staff for their work to produce the data set used in this study. The financial support for EARLINET in the ACTRIS Research Infrastructure Project by the European Union's Horizon 2020 research and innovation program under grant agreement no. 654169 and previously under grant agreement no. 262254 in the 7th Framework Programme (FP7/2007-2013) is gratefully acknowledged. In particular, the authors are thankful to the Italian EARLINET PIs (Maria Rita Perrone, Lecce; Nicola Spinelli, Naples; Gelsomina Pappalardo, Potenza; Simona Scollo, Serra La Nave) and their staff. Measurements at Lampedusa by ENEA were partly supported by the Italian Ministry for University and Research through the NextData and Ritmare projects. This study, especially the balloon campaign and part of the aircraft operations, has also been supported by the French space agency (CNES). The technical staff of SAFIRE, INSU Technical Division and the CNES Balloon sub-directorate (with special mention to Aurélien Bourdon and Gilles Dupouy) are warmly acknowledged for their contribution to the success of the experimental work. Contributions by Didier Bruneau (Latmos), Silvia Becagli (Univ. of Florence, Italy), Marco Cacciani (Univ. of Rome, Italy), Julian Groebner and Natalia Kouremeti (Physikalisch-Meteorologisches Observatorium Davos, World Radiation Center, Switzerland), and José Antonio Martinez Lozano (University of Valencia, Spain) are gratefully acknowledged. Barcelona station was partially supported by the Spanish Ministry of Economy and Competitivity (project TEC2012-34575) and of Science and Innovation (project UNPC10-4E-442) and FEDER funds, and by the Department of Economy and Knowledge of the Catalan Autonomous Government (grant 2014 SGR 583). Granada station was partially supported by the Andalusian Regional Government through project P12-RNM-2409 and by the Spanish Ministry of Science and Technology through project CGL2013-45410-R. Sahar Hassanzadeh, Constantino Muñoz-Porcar, Santi Bertolín and Diego Lange are also acknowledged for their kind assistance in operating the Menorca surface station, as well as François Gheusi, Brice Barret, Flore Tocquer, and Yves Meyerfeld for their contribution to the balloon campaign preparation and/or deployment. Claude Basdevant, Alexis Doerenbecher, and Fabien Bernard are acknowledged for their help and very useful tools in support of our drifting balloon experiment.

Edited by: O. Dubovik

\section{References}

Alados-Arboledas, L., Lyamani, H., and Olmo, F. J.: Aerosol size properties at Armilla, Granada (Spain), Q. J. Roy. Meteorol. Soc., 129, 1395-1413, 2003.

Alados-Arboledas, L., Alcántara, A., Olmo, F. J., Martínez-Lozano, J. A., Estellés, V., Cachorro, V., Silva, A. M., Horvath, H., Gangl, M., Díaz, A., Pujadas, M., Lorente, J., Labajo, A., Sorribas, M., and Pavese, G.: Aerosol columnar properties retrieved from CIMEL radiometers during VELETA 2002, Atmos. Environ., 42, 2654-2667, 2008.

Amiridis, V., Zerefos, C., Kazadzis, S., Gerasopoulos, E., Eleftheratos, K., Vrekoussis, M., Stohl, A., Mamouri, R. E., Kokkalis, P., Papayannis, A., Eleftheriadis, K., Diapouli, E., Keramitsoglou, I., Kontoes, C., Kotroni, V., Lagouvardos, K., Marinou, E., Gi- annakaki, E., Kostopoulou, E., Giannakopoulos, C., Richter, A., Burrows, J. P., and Mihalopoulos, N.: Impact of the 2009 Attica wild fires on the air quality in urban Athens, Atmos. Environ., 46, 536-544, 2012.

Ancellet, G., Pelon, J., Totems, J., Chazette, P., Bazureau, A., Sicard, M., Di Iorio, T., Dulac, F., and Mallet, M.: Long range transport and mixing of aerosol sources during the 2013 North American biomass burning episode: analysis of multiple lidar observations in the Western Mediterranean basin, Atmos. Chem. Phys. Discuss., 15, 32323-32365, doi:10.5194/acpd-15-323232015, 2015.

Antón, M., Valenzuela, A., Mateos, D., Alados, I., Foyo-Moreno, I., Olmo, F. J., and Alados-Arboledas, L.: Longwave aerosol radiative effects during an extreme desert dust event in southeastern Spain, Atmos. Res., 148, 18-23, 2014.

Baldassarre, G., Pozzoli, L., Schmidt, C. C., Unal, A., Kindap, T., Menzel, W. P., Whitburn, S., Coheur, P.-F., Kavgaci, A., and Kaiser, J. W.: Using SEVIRI fire observations to drive smoke plumes in the CMAQ air quality model: a case study over Antalya in 2008, Atmos. Chem. Phys., 15, 8539-8558, doi:10.5194/acp-15-8539-2015, 2015.

Balis, D. S., Amiridis, V., Nickovic, S., Papayannis, A., and Zerefos, C.: Optical properties of Saharan dust layers as detected by a Raman lidar at Thessaloniki, Greece, Geophys. Res. Lett., 31, L13104, doi:10.1029/2004GL019881, 2004.

Balis, D., Amiridis, V., Kazadzis, S., Papayannis, A., Tsaknakis, G., Tzortzakis, S., Kalivitis, N., Vrekoussis, M., Kanakidou, M., Mihalopoulos, N., Chourdakis, G., Nickovic, S., Pérez, C., Baldasano, J., and Drakakis, M.: Optical characteristics of desert dust over the East Mediterranean during summer: a case study, Ann. Geophys., 24, 807-821, doi:10.5194/angeo-24-807-2006, 2006.

Barnaba, F., Angelini, F., Curci, G., and Gobbi, G. P.: An important fingerprint of wildfires on the European aerosol load, Atmos. Chem. Phys., 11, 10487-10501, doi:10.5194/acp-1110487-2011, 2011.

Barragan, R., Sicard, M., Totems, J., Léon, J.-F., Renard, J.-B., Dulac, F., Mallet, M., Pelon, J., Alados-Arboledas, L., Amodeo, A., Augustin, P., Boselli, A., Bravo-Aranda, J. A., Burlizzi, P., Chazette, P., Comerón, A., D’Amico, G., Granados-Muñoz, M. J., Leto, G., Guerrero-Rascado, J. L., Madonna, F., Mona, L., Muñoz-Porcar, C., Pappalardo, G., Perrone, M. R., Pont, V., Rocadenbosch, F., Rodriguez, A., Scollo, S., Spinelli, N., Titos, G., Wang, X., and Zanmar Sanchez, R.: Characterization of aerosol transport and ageing during a multi-intrusion Saharan dust event over the western and central Mediterranean Basin in June 2013 in the framework of the ADRIMED/ChArMEx campaign, Atmos. Chem. Phys. Discuss., in preparation, 2016.

Benavent-Oltra, J. A., Granados-Muñoz, M. J., Pérez, D., Román, R., Bravo-Aranda, J. A., Titos, G., Guerrero-Rascado, J. L., Navas-Guzmán, F., Mallet, M., Ortiz-Amezcua, P., Lyamani, H., Valenzuela, A., Cazorla, A., Olmo, F. J., and Alados-Arboledas, L.: Remote-sensing and in-situ characterization of atmospheric aerosol during ChArMEx/ADRIMED over Granada, Atmos. Chem. Phys. Discuss., in preparation, 2016.

Berthier, S., Chazette, P., Couvert, P., Pelon, J., Dulac, F., Thieuleux, F., Moulin, C., and Pain, T.: Desert dust aerosol columnar properties over ocean and continental Africa from Lidar in-Space Technology Experiment (LITE) 
and Meteosat synergy, J. Geophys. Res., 111, D21202, doi:10.1029/2005JD006999, 2006.

Bessagnet, B., Hodzic, A., Vautard, R., Beekmann, M., Cheinet, S., Honoré, C., Liousse, C., and Rouil, L.: Aerosol modeling with CHIMERE: preliminary evaluation at the continental scale, Atmos. Environ., 38, 2803-2817, 2004.

Beuvier, J., Sevault, F., Herrmann, M., Kontoyiannis, H., Ludwig, W., Rixen, M., Stanev, E., Béranger, K., and Somot, S.: Modeling the Mediterranean Sea interannual variability during 1961-2000: Focus on the Eastern Mediterranean Transient, J. Geophys. Res., 115, C08017, doi:10.1029/2009JC005950, 2010.

Brauch, H. G.: Urbanization and natural disasters in the Mediterranean: Population growth and climate change in the 21 st century, in Building Safer Cities - The Future of Disaster Risk, edited by: Kreimer, A., Arnold, M., and Carlin, A., The World Bank, Washington D.C., Disaster Risk Management Series No.3, 149-164, 2003.

Cachier, H., Aulagnier, F., Sarda, R., Gautier, F., Masclet, P., Besombes, J. L., Marchand, N., Despiau, S., Croci, D., Mallet, M., Laj, P., Marinoni, A., Deveau, P. A., Roger, J. C., Putaud, J. P., Van Dingenen, R., Dell'Acqua, A., Viidanoja, J., Martins-Dos Santos, S., Liousse, C., Cousin, F., and Rosset, R.: Aerosol studies during the ESCOMPTE Experiment: an overview, Atmos. Res., 74, 547-563, doi:10.1016/j.atmosres.2004.06.013, 2005.

Cachorro, V. E., Toledano, C., Prats, N., Sorribas, M., Mogo, S., Berjon, A., Torres, B., Rodrigo, R., de la Rosa, J., and De Frutos, A. M.: The strongest desert dust intrusion mixed with smoke over the Iberian Peninsula registered with Sun photometry, J. Geophys. Res., 113, D14S04, doi:10.1029/2007JD009582, 2008.

Casasanta, G., di Sarra, A., Meloni, D., Monteleone, F., Pace, G., Piacentino, S., and Sferlazzo, D.: Large aerosol effects on ozone photolysis in the Mediterranean, Atmos. Environ., 45, 39373943, doi:10.1016/j.atmosenv.2011.04.065, 2011.

Chazette, P. and Liousse, C.: A case study of optical and chemical ground apportionment for urban aerosols in Thessaloniki, Atmos. Environ., 35, 2497-2506, doi:10.1016/S13522310(00)00425-8, 2001.

Chazette, P., Marnas, F., and Totems, J.: The mobile Water vapor Aerosol Raman LIdar and its implication in the framework of the HyMeX and ChArMEx programs: application to a dust transport process, Atmos. Meas. Tech., 7, 1629-1647, doi:10.5194/amt-71629-2014, 2014a.

Chazette, P., Marnas, F., Totems, J., and Shang, X.: Comparison of IASI water vapor retrieval with H2O-Raman lidar in the framework of the Mediterranean HyMeX and ChArMEx programs, Atmos. Chem. Phys., 14, 9583-9596, doi:10.5194/acp-14-95832014, 2014b.

Chazette, P., Totems, J., Ancellet, G., Pelon, J., and Sicard, M.: Temporal consistency of lidar observables during aerosol transport events in the framework of the ChArMEx/ADRIMED campaign at Menorca Island in June 2013, Atmos. Chem. Phys. Discuss., 15, 32723-32757, doi:10.5194/acpd-15-32723-2015, 2015.

Chenoweth J., Hadjinicolaou, P., Bruggemen, A., Lelieveld, J., Levin, Z., Lange, M. A., Xoplaki, E., and Hadkikakou, M.: Impact of climate change on the water resources of the eastern Mediterranean and middle east region: modeled 21st century, Water Resour. Res., 47, W06506, doi:10.1029/2010WR010269, 2011.
Ciardini, V., Di Iorio, T., Di Liberto, L., Tirelli, C., Casasanta, G., di Sarra, A., Fiocco, G., Fuà, D., and Cacciani, M.: Seasonal variability of tropospheric aerosols in Rome, Atmos. Res., 118, 205214, doi:10.1016/j.atmosres.2012.06.026, 2012.

Claeys, M., Roberts, G., Mallet, M., Sciare, J., Sellegri, K., Sauvage, B., Tulet, P., and Arndt, J.: Characterisation of a sea salt episode during ADRIMED campaign: ageing, transport and size distribution study, in preparation, 2016.

Collaud Coen, M., Weingartner, E., Schaub, D., Hueglin, C., Corrigan, C., Henning, S., Schwikowski, M., and Baltensperger, U.: Saharan dust events at the Jungfraujoch: detection by wavelength dependence of the single scattering albedo and first climatology analysis, Atmos. Chem. Phys., 4, 2465-2480, doi:10.5194/acp4-2465-2004, 2004.

Denjean, C., Cassola, F., Mazzino, A., Triquet, S., Chevaillier, S., Grand, N., Bourrianne, T., Momboisse, G., Sellegri, K., Schwarzenbock, A., Freney, E., Mallet, M., and Formenti, P.: Size distribution and optical properties of mineral dust aerosols transported in the western Mediterranean, Atmos. Chem. Phys. Discuss., 15, 21607-21669, doi:10.5194/acpd-15-21607-2015, 2015.

Déqué, M. and Somot, S.: Extreme precipitation and high resolution with Aladin, Idöjaras, Q. J. Hungarian Meteorol. Service, 112, 179-190, 2008.

Derimian, Y., Karnieli, A., Kaufman, Y. J., Andreae, M. O., Andreae, T. W., Dubovik, O., Maenhaut, W., Koren, I., and Holben, B. N.: Dust and pollution aerosols over the Negev desert, Israel: Properties, transport, and radiative effect, J. Geophys. Res., 111, D05205, doi:10.1029/2005JD006549, 2006.

Deschamps, P.-Y., Bréon, F.-M., Leroy, M., Podaire, A., Bricaud, A., Buriez, J. C., and Sèze, G.: The POLDER mission: Instrument characteristics and scientific objectives, IEEE Trans. Geosci. Remote Sens, 32, 598-615, 1994.

Di Biagio, C., di Sarra, A., Meloni, D., Monteleone, F., Piacentino, S., and Sferlazzo, D.: Measurements of Mediterranean aerosol radiative forcing and influence of the single scattering albedo, J. Geophys. Res., 114, D06211, doi:10.1029/2008JD011037, 2009.

Di Biagio, C., di Sarra, A., and Meloni, D.: Large atmospheric shortwave radiative forcing by Mediterranean aerosol derived from simultaneous ground-based and spaceborne observations, and dependence on the aerosol type and single scattering albedo, J. Geophys. Res., 115, D10209, doi:10.1029/2009JD012697, 2010.

Di Iorio, T., Di Sarra, A., Junkermann, W., Cacciani, M., Fiocco, G., and Fuà, D.: Tropospheric aerosols in the Mediterranean: 1. Microphysical and optical properties, J. Geophys. Res., 108, 4316, doi:10.1029/2002JD002815, 2003.

Di Iorio, T., di Sarra, A., Sferlazzo, D. M., Cacciani, M., Meloni, D., Monteleone, F., Fuà, D., and Fiocco, G.: Seasonal evolution of the tropospheric aerosol vertical profile in the central Mediterranean and role of desert dust, J. Geophys. Res., 114, D02201, doi:10.1029/2008JD010593, 2009.

Di Iorio, T., Di Biagio, C., di Sarra, A., Formenti, P., Gomez Amo, J.-L., Meloni, D., and Pace, G.: Height resolved aerosol optical properties at Lampedusa during ADRIMED, in preparation, 2016.

di Sarra, A., Pace, G., Meloni, D., De Silvestri, L., Piacentino, S., and Monteleone, F.: Surface shortwave radiative forcing of dif- 
ferent aerosol types in the central Mediterranean, Geophys. Res. Lett., 35, L02714, doi:10.1029/2007GL032395, 2008.

di Sarra, A., Di Biagio, C., Meloni, D., Monteleone, F., Pace, G., Pugnaghi, S., and Sferlazzo, D.: Shortwave and longwave radiative effects of the intense Saharan dust event of 25-26 March 2010 at Lampedusa (Mediterranean Sea), J. Geophys. Res., 116, D23209, doi:10.1029/2011JD016238, 2011.

di Sarra, A., Fuà, D., and Meloni, D.: Estimate of surface direct radiative forcing of desert dust from atmospheric modulation of the aerosol optical depth, Atmos. Chem. Phys., 13, 5647-5654, doi:10.5194/acp-13-5647-2013, 2013.

di Sarra, A., Sferlazzo, D., Meloni, D., Anello, F., Bommarito, C., Corradini, S., De Silvestri, L., Di Iorio, T., Monteleone, F., Pace, G., Piacentino, S., and Pugnaghi, S.: Empirical correction of multi filter rotating shadowband radiometer (MFRSR) aerosol optical depths for the aerosol forward scattering and development of a long-term integrated MFRSR-Cimel dataset at Lampedusa, Appl. Optics, 54, 2725-2737, doi:10.1364/AO.54.002725, 2015.

Dubovik, O. and King, M. D.: A flexible inversion algorithm for retrieval of aerosol optical properties from Sun and sky radiance measurements, J. Geophys. Res., 105, 20673-20696, doi:10.1029/2000JD900282, 2000.

Dubovik, O., Smirnov, A., Holben, B. N., King, M. D., Kaufman, Y. J., Eck, T. F., and Slutsker, I.: Accuracy assessment of aerosol optical properties retrieval from AERONET Sun and sky radiance measurements, J. Geophys. Res., 105, 9791-9806, doi:10.1029/2000JD900040, 2000.

Dubovik, O., Holben, B., Eck, T. F., Smirnov, A., Kaufman, Y. J., King, M. D., Tanré, D., and Slutsker, I.: Variability of absorption and optical properties of key aerosol types observed in worldwide locations, J. Atmos. Sci., 59, 590-608, doi:10.1175/15200469(2002)059<0590:VOAAOP> 2.0.CO;2, 2002.

Dubovik, O., Sinyuk, A., Lapyonok, T., Holben, B. N., Mishchenko, M., Yang, P., Eck, T. F., Volten, H., Muñoz, O., Veihelmann, B., van der Zande, W. J., Léon, J.-F., Sorokin, M., and Slutsker, I.: Application of spheroid models to account for aerosol particle nonsphericity in remote sensing of desert dust, J. Geophys. Res., 111, D11208, doi:10.1029/2005JD006619, 2006.

Dubuisson, P., Dessailly, D., Vesperini, M., and Frouin, R.: Water vapor retrieval over ocean using near-infrared radiometry, J. Geophys. Res., 109, D19106, doi:10.1029/2004JD004516, 2004.

Ducrocq, V., Braud, I., Davolio, S., Ferretti, R., Flamant, C., Jansa, A., Kalthoff, N., Richard, E., Taupier-Letage, I., Ayral, P. A., Belamari, S., Berne, A., Borga, M., Boudevillain, B., Bock, O., Boichard, J. L., Bouin, M. N., Bousquet, O., Bouvier, C., Chiggiato, J., Cimini, D., Corsmeier, U., Coppola, L., Cocquerez, P., Defer, E., Delanoë, J., Delrieu, G., Di Girolamo, P., Doerenbecher, A., Drobinski, P., Dufournet, Y., Fourrié, N., Gourley, J. J., Labatut, L., Lambert, D., Le Coz, J., Marzano, F. S., Montani, A., Nuret, M., Ramage, K., Rison, B., Roussot, O., Saïd, F., Schwarzenboeck, A., Testor, P., Van Baelen, J., Vincendon, B., Aran, M., and Tamayo, J.: HyMeXSOP1, the Field Campaign Dedicated to Heavy Precipitation and Flash-Flooding in Northwestern Mediterranean, B. Am. Meteorol. Soc., 95, 1083-1100, doi:10.1175/BAMS-D-12-00244.1, doi:10.1175/BAMS-D-12-00244.2, 2014

Dulac, F. and Chazette, P.: Airborne study of a multi-layer aerosol structure in the eastern Mediterranean observed with the airborne polarized lidar ALEX during a STAAARTE campaign (7 June
1997), Atmos. Chem. Phys., 3, 1817-1831, doi:10.5194/acp-31817-2003, 2003.

Eleftheriadis, K., Colbeck, I., Housiadaa, C., Lazaridis, M., Mihalopoulos, N., Mitsakou, C., Smolik, J., and Zdimal, V.: Size distribution, composition and origin of the submicron aerosol in the marine boundary layer during the eastern Mediterranean "SUB-AERO" experiment, Atmos. Environ., 40, 6245-6260, 2006.

Foltz, G. R. and McPhaden, M. J.: Impact of Saharan dust on tropical North Atlantic SST, J. Climate, 21, 5048-5060, doi:10.1175/2008JCLI2232.1, 2008.

Formenti, P., Boucher, O., Reiner, T., Sprung, D., Andreae, M. O., Wendisch, M., Wex, H., Kindred, D., Tzortziou, M., Vasaras, A., and Zerefos, C.: STAAARTE-MED 1998 summer airborne measurements over the Aegean Sea, 2. Aerosol scattering and absorption, and radiative calculations, J. Geophys. Res. 107, 4451, doi:10.1029/2001JD001536, 2002.

Formenti, P., Doussin, J. F., Desboeufs, K., Di Biagio, C., Denjean, C., Maillé, M., Zapf, P., Chevaillier, S., Oskanian, S., Triquet, S., Gaimoz, C., Grand, N., Laurent, B., Loisil, R., D’Anna, B., Même, A., Bove, M.-C., Massabo, D., Cassola, F., Prati, P., Roberts, G., Mallet, M., Pelon, J., Tanré, D., Parol, F., Gröbner, J., Di Iorio, T., Meloni, D., Pace, G., Gomez-Amo, J.-L., Sferlazzo, D., and di Sarra, A. G.: Characterisation of aerosols in a remote marine atmosphere in the West Mediterranean, Atmos. Chem. Phys. Discuss., in preparation, 2016.

Fotiadi, A., Hatzianastassiou, N., Drakakis, E., Matsoukas, C., Pavlakis, K. G., Hatzidimitriou, D., Gerasopoulos, E., Mihalopoulos, N., and Vardavas, I.: Aerosol physical and optical properties in the Eastern Mediterranean Basin, Crete, from Aerosol Robotic Network data, Atmos. Chem. Phys., 6, 53995413, doi:10.5194/acp-6-5399-2006, 2006.

Gangoiti, G., Millán, M., Salvador, R., and Mantilla, E.: Long-range transport and re-circulation of pollutants in the western Mediterranean during the project Regional Cycles of Air Pollution in the West-Central Mediterranean Area, Atmos. Environ., 35, 62676276, doi:10.1016/S1352-2310(01)00440-X, 2001.

García, O. E., Díaz, J. P., Expósito, F. J., Díaz, A. M., Dubovik, O., Derimian, Y., Dubuisson, P., and Roger, J.-C.: Shortwave radiative forcing and efficiency of key aerosol types using AERONET data, Atmos. Chem. Phys., 12, 5129-5145, doi:10.5194/acp-125129-2012, 2012.

García-Ruiz, J. M., López-Moreno, J. I., Vicente-Serrano, S. M., Lasanta-Martínez, T., and Beguería, S.: Mediterranean water resources in a global change scenario, Earth-Sci. Rev., 105, 121139, doi:10.1016/j.earscirev.2011.01.006, 2011.

Gard, E., Mayer, J. E., Morrical, B. D., Dienes, T., Fergenson, D. P., and Prather, K. A.: Real-time analysis of individual atmospheric aerosol particles: Design and performance of a portable ATOFMS, Anal. Chem., 69, 4083-4091, doi:10.1021/ac970540n, 1997.

Gerasopoulos, E., Andreae, M. O., Zerefos, C. S., Andreae, T. W., Balis, D., Formenti, P., Merlet, P., Amiridis, V., and Papastefanou, C.: Climatological aspects of aerosol optical properties in Northern Greece, Atmos. Chem. Phys., 3, 2025-2041, doi:10.5194/acp-3-2025-2003, 2003.

Gheusi, F., Durand, P., Verdier, N., Dulac, F., Attié, J.-L., Commun, P., Barret, B., Basdevant, C., Clenet, A., Derrien, S., Doerenbecher, El Amraoui, L., Fontaine, A., Hache, E., Jambert C., Jau- 
mouillé, E., Meyerfeld, Y., Roblou, L., and Tocquer, F.: Adapted ECC ozone sonde for long-duration flights aboard boundarylayer pressurized balloons, Atmos. Meas. Tech. Discuss., in review, 2015.

Gimeno, L., Drumond, A., Nieto, R., Trigo, R. M., and Stohl, A.: On the origin of continental precipitation, Geophys. Res. Lett., 37, L13804, doi:10.1029/2010GL043712, 2010

Giorgi, F. and Lionello, P.: Climate change projections for the Mediterranean region, Global Planet. Change, 63, 90-104, doi:10.1016/j.gloplacha.2007.09.005, 2008.

Giorgi, F., Coppola, E., Solmon, F., Mariotti, L., Sylla, M. B., Bi, X., Elguindi, N., Diro, G. T., Nair, V., Giuliani, G., Turuncoglu, U. U., Cozzini, S., Guttler, I., O’Brien, T. A., Tawfik, A. B., Shalaby, A., Zakey, A. S., Steiner, A. L., Stordal, F., Sloan, L. C., and Brankovic, C.: RegCM4: Model description and preliminary tests over multiple CORDEX domains, Clim. Res., 52, 7-29, doi:10.3354/cr01018, 2012.

Gross, D. S., Atlas, R., Rzeszotarski, J., Turetsky, E., Christensen, J., Benzaid, S., Olson, J., Smith, T., Steinberg, L., and Sulman, J.: Environmental chemistry through intelligent atmospheric data analysis, Environ. Model. Softw., 25, 760-769, doi:10.1016/j.envsoft.2009.12.001, 2010.

Guenther, A., Karl, T., Harley, P., Wiedinmyer, C., Palmer, P. I., and Geron, C.: Estimates of global terrestrial isoprene emissions using MEGAN (Model of Emissions of Gases and Aerosols from Nature), Atmos. Chem. Phys., 6, 3181-3210, doi:10.5194/acp-63181-2006, 2006.

Guerrero-Rascado, J. L., Olmo, F. J., Avilés-Rodríguez, I., NavasGuzmán, F., Pérez-Ramírez, D., Lyamani, H., and Alados Arboledas, L.: Extreme Saharan dust event over the southern Iberian Peninsula in september 2007: active and passive remote sensing from surface and satellite, Atmos. Chem. Phys., 9, 84538469, doi:10.5194/acp-9-8453-2009, 2009.

Hamonou, E., Chazette, P., Balis, D., Dulac, F., Schneider, X., Galani, E., Ancellet, G., and Papayannis, A.: Characterization of the vertical structure of Saharan dust export to the Mediterranean basin, J. Geophys. Res., 104, 22257-22270, 1999.

Harris, I, Jones, P., Osborn, T., and Lister, D.: Updated highresolution grids of monthly climatic observations - the cru ts 3.10 dataset, Int. J. Climatol., 34, 623-642, doi:10.1002/joc.3711, 2013.

Hashimoto, M., Nakajima, T., Dubovik, O., Campanelli, M., Che, H., Khatri, P., Takamura, T., and Pandithurai, G.: Development of a new data-processing method for SKYNET sky radiometer observations, Atmos. Meas. Tech., 5, 2723-2737, doi:10.5194/amt5-2723-2012, 2012.

Hatzianastassiou, N., Gkikas, A., Mihalopoulos, N., Torres, O., and Katsoulis, B. D.: Natural versus anthropogenic aerosols in the eastern Mediterranean basin derived from multiyear TOMS and MODIS satellite data, J. Geophys. Res., 114, D24202, doi:10.1029/2009JD011982, 2009.

Healy, R. M., Hellebust, S., Kourtchev, I., Allanic, A., O’Connor, I. P., Bell, J. M., Healy, D. A., Sodeau, J. R., and Wenger, J. C.: Source apportionment of PM2.5 in Cork Harbour, Ireland using a combination of single particle mass spectrometry and quantitative semi-continuous measurements, Atmos. Chem. Phys., 10, 9593-9613, doi:10.5194/acp-10-9593-2010, 2010.

Holben, B. N., Eck, T. F., Slutsker, I., Tanré, D., Buis, J. P., Setzer, A., Vermote, E., Reagan, J. A., Kaufman, Y. J., Nakajima,
T., Lavenu, F., Jankowiak, I., and Smirnov, A.: AERONET - A federated instrument network and data archive for aerosol characterization, Rem. Sens. Environ., 66, 1-16, doi:10.1016/S00344257(98)00031-5, 1998.

Horvath, H., Alados Arboledas, L., Olmo, F. J., Jovanovic, O., Gangl, M., Sanchez, C., Sauerzopf, H., and Seidl, S.: Optical characteristics of the aerosol in Spain and Austria and its effect on radiative forcing, J. Geophys. Res., 107, 4386, doi:10.1029/2001JD001472, 2002.

Johnson, G., Ristovski, Z., and Morawska, L.: Application of the VH-TDMA technique to coastal ambient aerosols, Geophys Res. Lett., 31, L16105, doi:10.1029/2004GL020126, 2004.

Kahn, R. A., Gaitley, B. J., Garay, M. J., Diner, D. J., Eck, T. F., Smirnov, A., and Holben, B. N.: Multiangle Imaging SpectroRadiometer global aerosol product assessment by comparison with the Aerosol Robotic Network, J. Geophys. Res., 115, D23209, doi:10.1029/2010JD014601, 2010.

Kalnay, E., Kanamitsu, M., Kistler, R., Collins, W., Deaven, D., Gandin, L., Iredell, M., Saha, S., White, G., Woollen, J., Zhu, Y., Leetmaa, A., Reynolds, R., Chelliah, M., Ebisuzaki, W., Higgins, W., Janowiak, J., Mo, K. C., Ropelewski, C., and Wang, J.: The NCEP/NCAR 40-year reanalysis project, B. Am. Meteorol. Soc., 77, 437-470, 1996.

Karol, Y., Tanré, D., Goloub, P., Vervaerde, C., Balois, J. Y., Blarel, L., Podvin, T., Mortier, A., and Chaikovsky, A.: Airborne sun photometer PLASMA: concept, measurements, comparison of aerosol extinction vertical profile with lidar, Atmos. Meas. Tech., 6, 2383-2389, doi:10.5194/amt-6-2383-2013, 2013.

Kaskaoutis, D. G., Kharol, S. K., Sifakis, N., Nastos, P. T., Sharma, A. R., Badarinath, K. V. S., and Kambezidis, H. D.: Satellite monitoring of the biomass-burning aerosols during the wildfires of August 2007 in Greece: Climate implications, Atmos. Environ., 45, 716-726, doi:10.1016/j.atmosenv.2010.09.043, 2011.

Kok, J. F.: A scaling theory for the size distribution of emitted dust aerosols suggests climate models underestimate the size of the global dust cycle, P. Natl. Acad. Sci. USA, 108, 1016-1021, doi:10.1073/pnas.1014798108, 2011.

Kubilay, N., Cokacar, T., and Oguz, T.: Optical properties of mineral dust outbreaks over the northeastern Mediterranean, J. Geophys. Res., 108, 4666, doi:10.1029/2003JD003798, 2003.

Kumar, D., Rocadenbosch, F., Sicard, M., Comeron, A., Muñoz, C., Lange, D., Tomás, S., and Gregorio, E.: Six-channel polychromator design and implementation for the UPC elastic/Raman LIDAR, in: SPIE Remote Sens., Int. Soc. Opt. Photon., Prague, Czech Republic, 81820W-81820W, 2011.

Lelieveld, J., Berresheim, H.. Borrmann, S., Crutzen, P. J., Dentener, F. J., Fischer, H., Feichter, J., Flatau, P. J., Heland, J., Holzinger1, R., Korrmann, R., Lawrence, M. G., Levin, Z., Markowicz, K. M., Mihalopoulos, N., Minikin, A. Ramanathan, V., de Reus, M., Roelofs, G. J., Scheeren, H. A., Sciare, J., Schlager, H., Schultz, M., Siegmund, P., Steil, B., Stephanou, E. G., Stier, P., Traub, M., Warneke C., Williams, J., and Ziereis, H.: Global air pollution crossroads over the Mediterranean, Science, 298, 794-799, doi:10.1126/science.1075457, 2002.

Léon, J.-F., Augustin, P., Mallet, M., Bourrianne, T., Pont, V., Dulac, F., Fourmentin, M., Lambert, D., and Sauvage, B.: Aerosol vertical distribution, optical properties and transport over Corsica (western Mediterranean), Atmos. Chem. Phys. Discuss., 15, 9507-9540, doi:10.5194/acpd-15-9507-2015, 2015. 
Lionello, P., Malanotte-Rizzoli, P., Boscolo, R., Alpert, P., Artale, V., Li, L., Luterbacher, J., May, W., Trigo, R., Tsimplis, M., Ulbrich, U., and Xoplaki, E.: The Mediterranean climate: An overview of the main characteristics and issues, in: The Mediterranean Climate Variability, edited by: Lionello, P., MalanotteRizzoli, P., and Boscolo, R., Developments in Earth and Environmental Sciences, Elsevier, 4, 1-26, 2006.

Liu, Y., Kahn, R. A., Chaloulakou, A., and Koutrakis, P.: Analysis of the impact of the forest fires in August 2007 on air quality of Athens using multi-sensor aerosol remote sensing data, meteorology and surface observations, Atmos. Environ., 43, 33103318, 2009.

Lyamani, H., Valenzuela, A., Perez-Ramirez, D., Toledano, C., Granados-Muñoz, M. J., Olmo, F. J., and Alados-Arboledas, L.: Aerosol properties over the western Mediterranean basin: temporal and spatial variability, Atmos. Chem. Phys., 15, 2473-2486, doi:10.5194/acp-15-2473-2015, 2015.

Mailler, S., Menut, L., di Sarra, A. G., Becagli, S., Di Iorio, T., Formenti, P., Bessagnet, B., Briant, Régis, Luis GómezAmo, J., Mallet, M., Rea, Géraldine, Siour, G., Sferlazzo, D. M., Traversi, R., Udisti, R., and Turquety, S.: On the radiative impact of aerosols on photolysis rates: comparison of simulations and observations in the Lampedusa island during the ChArMEx/ADRIMED campaign, Atmos. Chem. Phys. Discuss., 15, 7585-7643, doi:10.5194/acpd-15-7585-2015, 2015.

Mallet, M., Roger, J. C., Despiau, S., Dubovik, O., and Putaud, J. P.: Microphysical and optical properties of aerosol particles in urban zone during ESCOMPTE, Atmos. Res., 69, 73-97, doi:10.1016/j.atmosres.2003.07.001, 2003.

Mallet, M., Roger, J. C., Despiau, S., Putaud, J. P., and Dubovik, O.: A study of the mixing state of black carbon in urban zone, J. Geophys. Res., 109, D04202, doi:10.1029/2003JD003940, 2004.

Mallet, M., Van Dingenen, R., Roger, J. C., Despiau, S., and Cachier, H.: In situ airborne measurements of aerosol optical properties during photochemical pollution events. J. Geophys. Res., 110, D03205, doi:10.1029/2004JD005139, 2005.

Mallet, M., Pont, V., Liousse, C., Roger, J. C., and Dubuisson, P.: Simulation of aerosol radiative properties with the ORISAM-RAD model during a pollution event (ESCOMPTE 2001), Atmos. Environ., 40, 7696-7705, doi:10.1016/j.atmosenv.2006.08.031, 2006.

Mallet, M., Gomes, L., Solmon, F., Sellegri, K., Pont, V., Roger, J. C., Missamou, T., and Piazzola, J.: Calculations of key optical properties over the main anthropogenic aerosols over the Western French coastal Mediterranean Sea, Atmos. Res., 101, 396-411, doi:10.1016/j.atmosres.2011.03.008, 2011.

Mallet, M., Dubovik, O., Nabat, P., Dulac, F., Kahn, R., Sciare, J., Paronis, D., and Léon, J. F.: Absorption properties of Mediterranean aerosols obtained from multi-year ground-based remote sensing observations, Atmos. Chem. Phys., 13, 9195-9210, doi:10.5194/acp-13-9195-2013, 2013.

Markowicz, K. M., Flatau, P. J., Ramana, M. V., Crutzen, P. J., and Ramanathan, V.: Absorbing Mediterranean aerosols lead to a large reduction in the solar radiation at the surface, Geophys. Res. Lett., 29, 1968, doi:10.1029/2002GL015767, 2002.

Mariotti, A., Zeng, N., Yoon, J., Artale, V., Navarra, A., Alpert, P., and Li, L. Z. X.: Mediterranean water cycle changes: transition to drier 21 st century conditions in observations and CMIP3 simulations, Environ. Res. Lett., 3, 044001, doi:10.1088/17489326/3/4/044001, 2008.

Mariotti A., Pan, Y., Zeng, N., and Alessandri, A.: Long-term climate change in the Mediterranean region in the midst of decadal variability, Clim. Dynam., 44, 1437-1456, doi:10.1007/s00382015-2487-3, 2015.

Marticorena, B. and Bergametti, G.: Modeling the atmospheric dust cycle 1 . Design of a soil-derived dust production scheme, J. Geophys. Res., 100, 16415-16430, 1995.

McConnell, C. L., Formenti, P., Highwood, E. J., and Harrison, M. A. J.: Using aircraft measurements to determine the refractive index of Saharan dust during the DODO Experiments, Atmos. Chem. Phys., 10, 3081-3098, doi:10.5194/acp-10-30812010, 2010.

Meloni, D., di Sarra, A., DeLuisi, J., Di Iorio, T., Fiocco, G., Junkermann, W., and Pace, G.: Tropospheric aerosols in the Mediterranean: 2. Radiative effects through model simulations and measurements, J. Geophys. Res., 108, 4317, doi:10.1029/2002JD002807, 2003.

Meloni, D., di Sarra, A., Di Iorio, T., and Fiocco, G.: Direct radiative forcing of Saharan dust in the Mediterranean from measurements at Lampedusa Island and MISR space-borne observations, J. Geophys. Res., 109, D08206, doi:10.1029/2003JD003960, 2004.

Meloni, D., di Sarra, A., Pace, G., and Monteleone, F.: Aerosol optical properties at Lampedusa (Central Mediterranean). 2. Determination of single scattering albedo at two wavelengths for different aerosol types, Atmos. Chem. Phys., 6, 715-727, doi:10.5194/acp-6-715-2006, 2006.

Meloni, D., di Sarra, A., Monteleone, F., Pace, G., Piacention, S., and Sferlazzo, D. M.: Seasonal transport patterns of intense dust events at the Mediterranean island of Lampedusa, Atmos. Res., 88, 134-148, doi:10.1016/j.atmosres.2007.10.007, 2008.

Meloni, D., Junkermann, W., di Sarra, A., Cacciani, M., De Silvestri, L., Di Iorio, T., Estellés, V., Gómez-Amo, J. L., Pace, G., and Sferlazzo, D. M.: Altitude-resolved shortwave and longwave radiative effects of desert dust in the Mediterranean during the GAMARF campaign: indications of a net daily cooling in the dust layer, J. Geophys. Res.-Atmos., 120, 3386-3407, doi:10.1002/2014JD022312, 2015.

Meloni, D., di Sarra, A., Brogniez, G., Denjean, C., De Silvestri, L., Di Iorio, T., Formenti, P., Gomez-Amo, J.-L., Gröbner, J., Kouremeti, N., Mallet, M., and Pace, G.: Simulating vertically resolved SW and LW irradiances and infrared brightness temperatures measured at Lampedusa during the Charmex/ADRIMED campaign, in preparation, 2016.

Menut, L., Bessagnet, B., Khvorostyanov, D., Beekmann, M., Blond, N., Colette, A., Coll, I., Curci, G., Foret, G., Hodzic, A., Mailler, S., Meleux, F., Monge, J.-L., Pison, I., Siour, G., Turquety, S., Valari, M., Vautard, R., and Vivanco, M. G.: CHIMERE 2013: a model for regional atmospheric composition modelling, Geosci. Model Dev., 6, 981-1028, doi:10.5194/gmd6-981-2013, 2013.

Menut, L., Mailler, S., Siour, G., Bessagnet, B., Turquety, S., Rea, G., Briant, R., Mallet, M., Sciare, J., Formenti, P., and Meleux, F.: Ozone and aerosol tropospheric concentrations variability analyzed using the ADRIMED measurements and the WRF and CHIMERE models, Atmos. Chem. Phys., 15, 6159-6182, doi:10.5194/acp-15-6159-2015, 2015. 
Millán, M. M., Salvador, R., Mantilla, E., and Kallos, G.: Photooxidant dynamics in the Mediterranean basin in summer: Results from European research projects, J. Geophys. Res., 102, 88118823, doi:10.1029/96JD03610, 1997.

Mlawer, E. J., Taubman, S. J., Brown, P. D., Iacono, M. J., and Clough, S. A.: Radiative transfer for inhomogeneous atmospheres: RRTM, a validated correlated-k model for the longwave, J. Geophys. Res., 102, 16663-16682, 1997.

Moosmüller, H., Chakrabarty, R. K., and Arnott, W. P.: Aerosol light absorption and its measurement: A review, J. Quant. Spectrosc. Ra., 100, 844-878, 2009.

Morcrette, J. J.: Description of the radiation scheme in the ecmwf model, Tech. rep., ECMWF, 1989.

Mulcahy, J. P., O’Dowd, C. D., Jennings, S. G., and Ceburnis, D.: Significant enhancement of aerosol optical depth in marine air under high wind conditions, Geophys. Res. Lett., 35, L16810, doi:10.1029/2008GL034303, 2008.

Nabat, P., Solmon, F., Mallet, M., Kok, J. F., and Somot, S.: Dust emission size distribution impact on aerosol budget and radiative forcing over the Mediterranean region: a regional climate model approach, Atmos. Chem. Phys., 12, 10545-10567, doi:10.5194/acp-12-10545-2012, 2012.

Nabat, P., Somot, S., Mallet, M., Chiapello, I., Morcrette, J. J., Solmon, F., Szopa, S., Dulac, F., Collins, W., Ghan, S., Horowitz, L. W., Lamarque, J. F., Lee, Y. H., Naik, V., Nagashima, T., Shindell, D., and Skeie, R.: A 4-D climatology (1979-2009) of the monthly tropospheric aerosol optical depth distribution over the Mediterranean region from a comparative evaluation and blending of remote sensing and model products, Atmos. Meas. Tech., 6, 1287-1314, doi:10.5194/amt-6-1287-2013, 2013.

Nabat, P., Somot, S., Mallet, M., Sanchez-Lorenzo, A., and Wild, M.: Contribution of anthropogenic sulfate aerosols to the changing Euro-Mediterranean climate since 1980, Geophys. Res. Lett., 41, 5605-5611, doi:10.1002/2014GL060798, 2014.

Nabat, P., Somot, S., Mallet, M., Sevault, F., Chiacchio, M., and Wild, M.: Direct and semi-direct aerosol radiative effect on the Mediterranean climate variability using a coupled regional climate system model, Clim. Dynam., 44, 1127-1155, doi:10.1007/s00382-014-2205-6, 2015a.

Nabat, P., Somot, S., Mallet, M., Michou, M., Sevault, F., Driouech, F., Meloni, D., di Sarra, A., Di Biagio, C., Formenti, P., Sicard, M., Léon, J.-F., and Bouin, M.-N.: Dust aerosol radiative effects during summer 2012 simulated with a coupled regional aerosolatmosphere-ocean model over the Mediterranean, Atmos. Chem. Phys., 15, 3303-3326, doi:10.5194/acp-15-3303-2015, 2015 b.

Nicolas, J., Mallet, M., Roberts, G., Denjean, C., Formenti, P., Fresney, E., Sellegri, K., Borgniez, G., Bourrianne, T., Piguet, B., Torres, B., Dubuisson, P., and Dulac, F.: Aerosol direct radiative forcing at a regional scale over the western Mediterranean in summer within the ADRIMED project: airborne observations compared to GAME simulations, Atmos. Chem. Phys. Discuss., in preparation, 2016.

Noilhan, J. and Mahfouf, J.-F.: The ISBA land surface parameterisation scheme, Global Planet. Change, 13, 145-159, doi:10.1016/0921-8181(95)00043-7, 1996.

Ortiz-Amezcua, P., Guerrero-Rascado, J. L., Granados-Muñoz, M. J., Bravo-Aranda, J. A., and Alados-Arboledas, L.: Characterization of atmospheric aerosols for a long range transport of biomass burning particles from canadian forest fires over the southern iberian peninsula in July 2013, Optica Pura y Aplicada, 47, 4349, 2014

Otto, S., Bierwirth, E., Weinzierl, B., Kandler, K., Esselborn, M., Tesche, M., Schladitz, A., Wendisch, M., and Trautmann, T.: Solar radiative effects of a Saharan dust plume observed during SAMUM assuming spheroidal model particles, Tellus B, 61, 270296, doi:10.1111/j.1600-0889.2008.00389.x, 2009.

Ritter, B. and Geleyn, J.-F.: A comprehensive radiation scheme for numerical weather prediction models with potential applications in climate simulations, Mon. Weather Rev., 120, 303-325, 1992.

Pace, G., Meloni, D., and di Sarra, A.: Forest fire aerosol over the Mediterranean basin during summer 2003, J. Geophys. Res., 110, D21202, doi:10.1029/2005JD005986, 2005.

Pace, G., di Sarra, A., Meloni, D., Piacentino, S., and Chamard, P.: Aerosol optical properties at Lampedusa (Central Mediterranean). 1. Influence of transport and identification of different aerosol types, Atmos. Chem. Phys., 6, 697-713, doi:10.5194/acp-6-697-2006, 2006.

Papadimas, C. D., Hatzianastassiou, N., Matsoukas, C., Kanakidou, M., Mihalopoulos, N., and Vardavas, I.: The direct effect of aerosols on solar radiation over the broader Mediterranean basin, Atmos. Chem. Phys., 12, 7165-7185, doi:10.5194/acp-12-71652012, 2012.

Papayannis, A., Balis, D., Amiridis, V., Chourdakis, G., Tsaknakis, G., Zerefos, C., Castanho, A. D. A., Nickovic, S., Kazadzis, S., and Grabowski, J.: Measurements of Saharan dust aerosols over the Eastern Mediterranean using elastic backscatter-Raman lidar, spectrophotometric and satellite observations in the frame of the EARLINET project, Atmos. Chem. Phys., 5, 2065-2079, doi:10.5194/acp-5-2065-2005, 2005.

Papayannis, A., Amiridis, V., Mona, L., Tsaknakis, G., Balis, D., Bösenberg, J., Chaikovski, A., De Tomasi, F., Grigorov, I., Mattis, I., Mitev, V., Müller, D., Nickovic, S., Pérez, C., Pietruczuk, A., Pisani, G., Ravetta, F., Rizi, V., Sicard, M., Trickl, T., Wiegner, M., Gerding, M., Mamouri, R. E., D’Amico, G., and Pappalardo, G.: Systematic lidar observations of Saharan dust over Europe in the frame of EARLINET (2000-2002), J. Geophys. Res., 113, D10204, doi:10.1029/2007JD009028, 2008.

Pappalardo, G., Amodeo, A., Mona, L., Pandolfi, M, Pergola, N., and Cuomo, V.: Raman lidar observations of aerosol emitted during the 2002 Etna eruption, Geophys. Res. Lett., 31, L05120, doi:10.1029/2003GL019073, 2004.

Pappalardo, G., Amodeo, A., Apituley, A., Comeron, A., Freudenthaler, V., Linné, H., Ansmann, A., Bösenberg, J., D’Amico, G., Mattis, I., Mona, L., Wandinger, U., Amiridis, V., AladosArboledas, L., Nicolae, D., and Wiegner, M.: EARLINET: towards an advanced sustainable European aerosol lidar network, Atmos. Meas. Tech., 7, 2389-2409, doi:10.5194/amt-7-23892014, 2014.

Péré, J.C., Mallet, M., Pont, V., and Bessagnet, B.: Impact of aerosol direct radiative forcing on the radiative budget, surface heat fluxes, and atmospheric dynamics during the heat wave of summer 2013 over western Europe: A modelling study, J. Geophys Res., 116, D23119, doi:10.1029/2011JD016240, 2011.

Pérez, C., Sicard, M., Jorba, O., Comerón, A., and Baldasano, J. M.: Summertime re-circulations of air pollutants over the northeastern Iberian coast observed from systematic EARLINET lidar measurements in Barcelona, Atmos. Environ., 38, 3983-4000, 2004. 
Pérez, C., Nickovic, S., Baldasano, J. M., Sicard, M., Rocadenbosch, F., and Cachorro, V. E.: A long Saharan dust event over the western Mediterranean: Lidar, sun photometer observations, and regional dust modeling. J, Geophys. Res., 111, D15214, doi:10.1029/2005JD006579, 2006.

Petzold, A., Onasch, T., Kebabian, P., and Freedman, A.: Intercomparison of a Cavity Attenuated Phase Shift-based extinction monitor (CAPS PMex) with an integrating nephelometer and a filterbased absorption monitor, Atmos. Meas. Tech., 6, 1141-1151, doi:10.5194/amt-6-1141-2013, 2013.

Piazzola, J., Tedeschi, G., and Demoisson, A.: A model for a transport of sea-spray Aerosols in the coastal zone, Bound. Lay. Meteorol., 155, 329-350, 2015.

Ramanathan, V., Crutzen, P. J., Lelieveld, J., Mitra, A. P., Althausen, D., Anderson, J., Andreae, M. O., Cantrell, W., Cass, G., Chung, C. E., Clarke, A. D., Coakley, J. A., Collins, W. D., Conant, W. C., Dulac, F., Heintzenberg, J., Heymsfield, A. J., Holben, B., Howell, S., Hudson, J., Jayaraman, A., Kiehl, J. T., Krishnamurti, T. N., Lubin, D., MacFarquhar, G., Novakov, T., Ogren, J. A., Podgorny, I. A., Prather, K., Priestley, K., Prospero, J. M., Quinn, P. K., Rajeev, K., Rasch, P., Rupert, S., Sadourny, R., Satheesh, S. K., Shaw, G. E., Sheridan, P., and Valero, F. P. J.: Indian Ocean experiment: An integrated analysis of the climate forcing and effects of the great Indo-Asian haze, J. Geophys. Res., 106, 2837128398, doi:10.1029/2001JD900133, 2001.

Ravetta, F., Ancellet, G., Colette, A., and Schlager, H.: Longrange transport and tropospheric ozone variability in the western Mediterranean region during the Intercontinental Transport of Ozone and Precursors (ITOP-2004) campaign, J. Geophys. Res., 112, 1-12, doi:10.1029/2006JD007724, 2007.

Rea, G., Turquety, S., Menut, L., Briant, R., Mailler, S., and Siour, G.: Source contributions to 2012 summertime aerosols in the Euro-Mediterranean region, Atmos. Chem. Phys. Discuss., 15, 8191-8242, doi:10.5194/acpd-15-8191-2015, 2015.

Renard, J.-B., Dulac, F., Berthet, G., Lurton, T., Vignelles, D., Jégou, F., Tonnelier, T., Thaury, C., Jeannot, M., Couté, B., Akiki, R., Mineau, J.-L., Verdier, N., Mallet, M., Gensdarmes, F., Charpentier, P., Mesmin, S., Duverger, V., Dupont, J.-C., Elias, T., Crenn, V., Sciare, J., Giacomoni, J., Gobbi, M., Hamonou, E., Olafsson, H., Dagsson-Waldhauserova, P., Camy-Peyret, C., Mazel, C., Décamps, T., Piringer, M., Surcin, J., and Daugeron, D.: LOAC: a small aerosol optical counter/sizer for ground-based and balloon measurements of the size distribution and nature of atmospheric particles - Part 1: Principle of measurements and instrument evaluation, Atmos. Meas. Tech. Discuss., 8, 12031259, doi:10.5194/amtd-8-1203-2015, 2015a.

Renard, J.-B., Dulac, F., Berthet, G., Lurton, T., Vignelle, D., Jégou, F., Tonnelier, T., Thaury, C., Jeannot, M., Couté, B., Akiki, R., Mineau, J.-L., Verdier, N., Mallet, M., Gensdarmes, F., Charpentier, P., Mesmin, S., Duverger, V., Dupont, J.-C., Elias, T., Crenn, V., Sciare, J., Giacomoni, J., Gobbi, M., Hamonou, E., Olafsson, H., Dagsson-Waldhauserova, P., Camy-Peyret, C., Mazel, C., Décamps, T., Piringer, M., Surcin, J., and Daugeron, D.: LOAC: a small aerosol optical counter/sizer for ground-based and balloon measurements of the size distribution and nature of atmospheric particles - Part 2: First results from balloon and unmanned aerial vehicle flights, Atmos. Meas. Tech. Discuss., 8, 1261-1299, doi:10.5194/amtd-8-1261-2015, 2015 b.
Ripoll, A., Minguillón, M. C., Pey, J., Pérez, N., Querol, X., and Alastuey, A.: Joint analysis of continental and regional background environments in the western Mediterranean: $\mathrm{PM}_{1}$ and $\mathrm{PM}_{10}$ concentrations and composition, Atmos. Chem. Phys., 15, 1129-1145, doi:10.5194/acp-15-1129-2015, 2015.

Roger, J. C., Mallet, M., Dubuisson, P., Cachier, H., Vermote, E., Dubovik, O., and Despiau, S.: A synergetic approach for estimating the local direct aerosol forcing: application to an urban zone during the Experience sur Site pour Contraindre les Modèles de Pollution et de Transport d'Emission (ESCOMPTE) experiment, J. Geophys. Res., 111, D13208, doi:10.1029/2005JD006361, 2006.

Royer, P., Raut, J.-C., Ajello, G., Berthier, S., and Chazette, P.: Synergy between CALIOP and MODIS instruments for aerosol monitoring: application to the Po Valley, Atmos. Meas. Tech., 3, 893907, doi:10.5194/amt-3-893-2010, 2010.

Ryder, C. L., Highwood, E. J., Rosenberg, P. D., Trembath, J., Brooke, J. K., Bart, M., Dean, A., Crosier, J., Dorsey, J., Brindley, H., Banks, J., Marsham, J. H., McQuaid, J. B., Sodemann, H., and Washington, R.: Optical properties of Saharan dust aerosol and contribution from the coarse mode as measured during the Fennec 2011 aircraft campaign, Atmos. Chem. Phys., 13, 303325, doi:10.5194/acp-13-303-2013, 2013.

Saha, A., Mallet, M., Roger, J. C., Dubuisson, P., Piazzola, J., and Despiau, S.: One year measurements of aerosol optical properties over an urban coastal site: Effect on local direct radiative forcing, Atmos. Res., 90, 195-202, doi:10.1016/j.atmosres.2008.02.003, 2008.

Sanchez-Gomez, E., Somot, S., and Mariotti, A.: Future changes in the Mediterranean water budget projected by an ensemble of regional climate models, Geophys. Res. Lett., 36, L21401, doi:10.1029/2009GL040120, 2009.

Salameh, T., Drobinski, P., Menut, L., Bessagnet, B., Flamant, C., Hodzic, A., and Vautard, R.: Aerosol distribution over the western Mediterranean basin during a Tramontane/Mistral event, Ann. Geophys., 25, 2271-2291, doi:10.5194/angeo-25-22712007, 2007.

Santese, M., Perrone, M. R., Zakey, A. S., De Tomasi, F., and Giorgi, F.: Modeling of Saharan dust outbreaks over the Mediterranean by RegCM3: case studies, Atmos. Chem. Phys., 10, 133156, doi:10.5194/acp-10-133-2010, 2010.

Sassen, K.: Lidar backscatter depolarization technique for cloud and aerosol research, in: Light Scattering by Nonspherical Particles: Theory, Measurements, and Applications, edited by: Mishchenko, M., Hovenier, J. W., and Travis, L. D., Academic Press, San Diego, 393-417, 1999.

Schepanski, K., Tegen, I., Laurent, B., Heinold, B., and Macke, A.: A new Saharan dust source activation frequency map derived from MSG-SEVIRI IR-channels, Geophys. Res. Lett., 34, 18803, doi:10.1029/2007GL030168, 2007.

Sciare, J., Cachier, H., Oikonomou, K., Ausset, P., Sarda-Estève, R., and Mihalopoulos, N.: Characterization of carbonaceous aerosols during the MINOS campaign in Crete, July-August 2001: a multi-analytical approach, Atmos. Chem. Phys., 3, 17431757, doi:10.5194/acp-3-1743-2003, 2003.

Sciare, J., Oikonomou, K., Favez, O., Liakakou, E., Markaki, Z., Cachier, H., and Mihalopoulos, N.: Long-term measurements of carbonaceous aerosols in the Eastern Mediterranean: evidence of 
long-range transport of biomass burning, Atmos. Chem. Phys., 8, 5551-5563, doi:10.5194/acp-8-5551-2008, 2008.

Schicker, I., Radanovics, S., and Seibert, P.: Origin and transport of Mediterranean moisture and air, Atmos. Chem. Phys., 10, 50895105, doi:10.5194/acp-10-5089-2010, 2010.

Schroeder, W., Csiszar, I., Giglio, L., and Schmidt, C. C.: On the use of fire radiative power, area, and temperature estimates to characterize biomass burning via moderate to coarse spatial resolution remote sensing data in the Brazilian Amazon, J. Geophys. Res., 115, D21121, doi:10.1029/2009JD013769, 2010.

Sellegri, K., Rose, C., Culot, A., Sauvage, S., Roberts, G., Marchand, N., Pey, J., Sciare, J., Bourriane, T., Mallet, M., and Dulac, F.: Spatial extent, occurrence and precursors of nucleation events over the western Mediterranean basin, in preparation, 2016.

Sellitto, P., di Sarra, A., Corradini, S., Boichu, M., Herbin, H., Dubuisson, P., Sèze, G., Meloni, D., Monteleone, F., Merucci, L., Rusalem, J., Salerno, G., Briole, P., and Legras, B.: Synergistic use of Lagrangian dispersion modelling, satellite and surface remote sensing measurements for the investigation of volcanic plumes: the Mount Etna eruption of 25-27 October 2013, Atmos. Chem. Phys. Discuss., 15, 31335-31383, doi:10.5194/acpd-1531335-2015, 2015.

Sicard, M., Rocadenbosch, F., Reba, M. N. M., Comerón, A., Tomás, S., García-Vízcaino, D., Batet, O., Barrios, R., Kumar, D., and Baldasano, J. M.: Seasonal variability of aerosol optical properties observed by means of a Raman lidar at an EARLINET site over Northeastern Spain, Atmos. Chem. Phys., 11, 175-190, doi:10.5194/acp-11-175-2011, 2011.

Sicard, M., Bertolín, S., Mallet, M., Dubuisson, P., and Comerón, A.: Estimation of mineral dust long-wave radiative forcing: sensitivity study to particle properties and application to real cases in the region of Barcelona, Atmos. Chem. Phys., 14, 9213-9231, doi:10.5194/acp-14-9213-2014, 2014a.

Sicard, M., Bertolín, S., Muñoz, C., Rodríguez, A., Rocadenbosch, F., and Comerón, A.: Separation of aerosol fine- and coarsemode radiative properties: Effect on the mineral dust longwave, direct radiative forcing, Geophys. Res. Lett., 41, 6978-6985, doi:10.1002/2014GL060946, 2014b.

Sicard, M., Barragan, R., Muñoz-Porcar, C., Comerón, A., Mallet, M., Dulac, F., Pelon, J., Alados-Arboledas, L., Amodeo, A., Boselli, A., Bravo-Aranda, J. A., D’Amico, G., GranadosMuñoz, M. J., Leto, G., Guerrero-Rascado, J. L., Madonna, F., Mona, L., Pappalardo, G., Perrone, M. R., Burlizzi, P., Rocadenbosch, F., Rodríguez-Gómez, A., Scollo, Spinelli, N., Titos, G., Wang, X., and Zanmar Sanchez, R.: Contribution of EARLINET/ACTRIS to the summer 2013 Special Observing Period of the ChArMEx project, Óptica Pura y Aplicada, submitted, 2015a.

Sicard, M., Barragan, Dulac, F., Alados-Arboledas, L., and Mallet, M.: Aerosol optical, microphysical and ratiative properties at three regional background insular sites in the western Mediterranean Basin, Atmos. Chem. Phys. Discuss., in press, $2015 \mathrm{~b}$.

Solmon, F., Giorgi., F., and Liousse, C.: Aerosol modelling for regional climate studies: application to anthropogenic particles and evaluation over a European/African domain, Tellus, 58B, 51-72, doi:10.1111/j.1600-0889.2005.00155.x, 2006.

Solmon, F., Mallet, M., Elguindi, N., Giorgi, F., Zakey, A., and Konaré, A.: Dust aerosol impact on regional precipitation over western Africa: mechanisms and sensitivity to absorption properties, Geophys. Res. Lett., 35, L24705, doi:10.1029/2008GL035900, 2008.

Spada, M., Jorba, O., Pérez García-Pando, C., Janjic, Z., and Baldasano, J. M.: Modeling and evaluation of the global sea-salt aerosol distribution: sensitivity to size-resolved and sea-surface temperature dependent emission schemes, Atmos. Chem. Phys., 13, 11735-11755, doi:10.5194/acp-13-11735-2013, 2013.

Tafuro, A. M., Barnaba, F., De Tomasi, F., Perrone, M. R., and Gobbi, G. P.: Saharan dust particle properties over the central Mediterranean, Atmos. Res., 81, 67-93, 2006.

Tafuro, A. M., Kinne, S., De Tomasi, F., and Perrone, M. R.: Annual cycle of aerosol direct radiative effect over southeast Italy and sensitivity studies, J. Geophys. Res., 112, D20202, doi:10.1029/2006JD008265, 2007.

Tanré, D., Kaufman, Y. J., Herman, M., and Mattoo, S.: Remote sensing of aerosol properties over oceans using the MODIS/EOS spectral radiances, J. Geophys. Res., 102, 16971-16988, 1997.

Tanré, D., Bréon, F. M., Deuzé, J. L., Dubovik, O., Ducos, F., François, P., Goloub, P., Herman, M., Lifermann, A., and Waquet, F.: Remote sensing of aerosols by using polarized, directional and spectral measurements within the A-Train: the PARASOL mission, Atmos. Meas. Tech., 4, 1383-1395, doi:10.5194/amt-4-1383-2011, 2011.

Tegen, I., Harrison, S. P., Kohfeld, K. E., and Prentice, I. C.: Impact of vegetation and preferential source areas on global dust aerosol: Results from a model study, J. Geophys. Res., 107, 4576, doi:10.1029/2001JD000963, 2002.

Thieuleux, F., Moulin, C., Bréon, F. M., Maignan, F., Poitou, J., and Tanré, D.: Remote sensing of aerosols over the oceans using MSG/SEVIRI imagery, Ann. Geophys., 23, 3561-3568, doi:10.5194/angeo-23-3561-2005, 2005.

Torres, B., Dubovik, O., Fuertes, D., Lapyonok, T., Toledano, C., Schuster, G. L., Goloub, P., Blarel, L., Barreto, A., Mallet, M., and Tanré, D.: Advanced characterization of aerosol properties from measurements of spectral optical thickness of the atmosphere, in preparation, 2016.

Turquety, S., Menut, L., Bessagnet, B., Anav, A., Viovy, N., Maignan, F., and Wooster, M.: APIFLAME v1.0: high-resolution fire emission model and application to the Euro-Mediterranean region, Geosci. Model Dev., 7, 587-612, doi:10.5194/gmd-7-5872014, 2014.

Vaishya, A., Jennings, S. G., and O'Dowd, C.: Wind-driven influences on aerosol light scattering in north-east Atlantic air, Geophys. Res. Lett., 39, L05805, doi:10.1029/2011GL050556, 2012.

Valenzuela, A., Olmo, F. J., Lyamani, H., Antón, M., Quirantes, A., and Alados-Arboledas, L.: Aerosol radiative forcing during African desert dust events (2005-2010) over Southeastern Spain, Atmos. Chem. Phys., 12, 10331-10351, doi:10.5194/acp12-10331-2012, 2012.

Vialard, J., Duvel, J.-P., McPhaden, M., Bouruet-Aubertot, P., Ward, B., Key, E., Bourras, D., Weller, R., Minnett, P., Weill, A., Cassou, C., Eymard, L., Fristedt, T., Basdevant, C., Dandoneau, Y., Duteil, O., Izumo, T., de Boyer Montegut, C., Masson, S., Marsac, F., Menkes, C., and Kennan, S.: Cirene: Air-sea interactions in the Seychelles-Chagos thermocline ridge region, B. Am. Meteorol. Soc., 90, 45-61, doi:10.1175/2008BAMS2499.1, 2009.

Villani, P., Picard, D., Marchand, N., and Laj, P.: Design and validation of a 6-volatility tandem differential mobil- 
ity analyzer (VTDMA), Aerosol Sci. Technol., 41, 898-906, doi:10.1080/02786820701534593, 2007.

Wang, Y., Sartelet, K. N., Bocquet, M., Chazette, P., Sicard, M., D’Amico, G., Léon, J. F., Alados-Arboledas, L., Amodeo, A., Augustin, P., Bach, J., Belegante, L., Binietoglou, I., Bush, X., Comerón, A., Delbarre, H., García-Vízcaino, D., GuerreroRascado, J. L., Hervo, M., Iarlori, M., Kokkalis, P., Lange, D., Molero, F., Montoux, N., Muñoz, A., Muñoz, C., Nicolae, D., Papayannis, A., Pappalardo, G., Preissler, J., Rizi, V., Rocadenbosch, F., Sellegri, K., Wagner, F., and Dulac, F.: Assimilation of lidar signals: application to aerosol forecasting in the western Mediterranean basin, Atmos. Chem. Phys., 14, 12031-12053, doi:10.5194/acp-14-12031-2014, 2014.

Waquet, F., Cornet, C., Deuzé, J.-L., Dubovik, O., Ducos, F., Goloub, P., Herman, M., Lapyonok, T., Labonnote, L. C., Riedi, J., Tanré, D., Thieuleux, F., and Vanbauce, C.: Retrieval of aerosol microphysical and optical properties above liquid clouds from POLDER/PARASOL polarization measurements, Atmos. Meas. Tech., 6, 991-1016, doi:10.5194/amt-6-991-2013, 2013.

Wolke, R., Schroeder, W., Schroedner, R., and Renner, E.: Influence of grid resolution and meteorological forcing on simulated European air quality: A sensitivity study with the modeling system COSMO-MUSCAT, Atmos. Environ., 53, 110-130, 2012.
Yue, X., Liao, H., Wang, H. J., Li, S. L., and Tang, J. P.: Role of sea surface temperature responses in simulation of the climatic effect of mineral dust aerosol, Atmos. Chem. Phys., 11, 60496062, doi:10.5194/acp-11-6049-2011, 2011.

Zakey, A. S., Solmon, F., and Giorgi, F.: Implementation and testing of a desert dust module in a regional climate model, Atmos. Chem. Phys., 6, 4687-4704, doi:10.5194/acp-6-4687-2006, 2006.

Zakey, A. S., Giorgi, F., and Bi, X.: Modeling of sea salt in a regional climate model: Fluxes and radiative forcing, J. Geophys. Res., 113, D14221, doi:10.1029/2007JD009209, 2008.

Zanis, P., Ntogras, C., Zakey, A., Pytharoulis, I., and Karacostas, T.: Regional climate feedback of anthropogenic aerosols over Europe using RegCM3, Clim. Res., 52, 267-278, doi:10.3354/cr01070, 2012.

Zhu, A., Ramanathan, V., Li, F., and Kim, D.: Dust plumes over the Pacific, Indian, and Atlantic oceans: Climatology and radiative impact, J. Geophys. Res., 112, D16208, doi:10.1029/2007JD008427, 2007. 